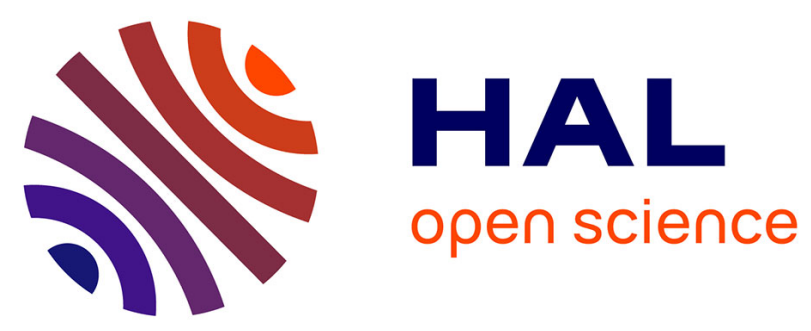

\title{
Soil and plant health in relation to dynamic sustainment of Eh and pH homeostasis: A review
}

Olivier Husson, Jean-Pierre Sarthou, Lydia Bousset, Alain Ratnadass, Hans-Peter Schmidt, John Kempf, Benoit Husson, Sophie Tingry, Jean-Noël Aubertot, Jean-Philippe Deguine, et al.

\section{To cite this version:}

Olivier Husson, Jean-Pierre Sarthou, Lydia Bousset, Alain Ratnadass, Hans-Peter Schmidt, et al.. Soil and plant health in relation to dynamic sustainment of Eh and $\mathrm{pH}$ homeostasis: A review. Plant and Soil, 2021, 466 (1-2), pp.391-447. 10.1007/s11104-021-05047-z . hal-03287577

\section{HAL Id: hal-03287577 \\ https://hal.inrae.fr/hal-03287577}

Submitted on 14 Oct 2021

HAL is a multi-disciplinary open access archive for the deposit and dissemination of scientific research documents, whether they are published or not. The documents may come from teaching and research institutions in France or abroad, or from public or private research centers.
L'archive ouverte pluridisciplinaire HAL, est destinée au dépôt et à la diffusion de documents scientifiques de niveau recherche, publiés ou non, émanant des établissements d'enseignement et de recherche français ou étrangers, des laboratoires publics ou privés. 
a. CIRAD, UPR AIDA, F-34398 Montpellier, France.

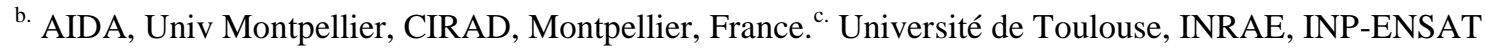

Toulouse, UMR AGIR, F-31320, Castanet-Tolosan, France

d. INRAE, UMR 1349 IGEPP - Agrocampus Ouest Rennes- Université Rennes 1 ; BP35327

e. CIRAD, UPR HortSys, F-97455 Saint-Pierre, Réunion, France

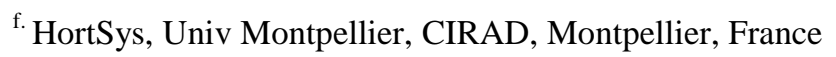

g. Ithaka Institute for Carbon Strategies, Ancienne Eglise 9, Arbaz 1974, Switzerland

h. Advancing Eco Agriculture, 4551 Parks West Rd, Middlefield Ohio 44062, United States

i. IDEEAQUACULTURE, Parc Euromedecine 2, 39 Rue Jean Giroux, 34080 Montpellier, France

${ }^{j}$. Institut Européen des Membranes, IEM UMR-5635, Université de Montpellier, ENSCM, CNRS, Place Eugène Bataillon, 34095 Montpellier Cedex 5, France

k. CIRAD, UMR PVBMT, F-97410 La Réunion, Saint Pierre, France

Glossary

ABA: Abscissic acid

ACP: Agroecological Crop Protection

AsA: Ascorbic Acid

ORCID numbers : Olivier Husson : 0000-0001-9587-5819; Jean Pierre Sarthou : 0000-0003-4096-6291; Lydia Bousset : 0000-0002-1600-1900 ; Alain Ratnadass : 0000-0002-8873-5671 ; Hans-Peter Schmidt : 0000-0001-8275-7506 ; Sophie Tingry: /0000-0001-6311-9330 ; Jean-Noël Aubertot : /0000-0001-60481553 ; Jean-Philippe Deguine : 0000-0002-3689-3707 ; François-Régis Goebel : 0000-0002-5438-1078 ; Jay Ram Lamichhane : 0000-0001-9780-0941

ASC: Reduced AsA

ATP: Adenosine Tri Phosphate

DHA: De Hydro Ascorbic acid (Oxidized AsA)

EC: Electrical conductivity

Eh: Redox Potential

ET: Ethylene

G x E x M x P Interactions: Genotype x Environment x Management x Pest sensu lato interactions GSH: Reduced Glutathione

GSSG: Oxidized Glutathione

ISR: Induced Systemic resistance

JA: Jasmonic Acid

NADPH: Reduced form of Nicotinamide Adenine Dinucleotide Phosphate

NO: Nitric Oxide

$\mathrm{pH}$ : Hydrogen potential

RAS: Root-Adhering Soil

ROS: Reactive Oxygen species

SA: Salicylic Acid 


\section{Introduction}

"Research is to see what everybody has seen, and think what nobody has thought" Albert Szent-Gyorgyi, Nobel prize laureate.

Since the late $19^{\text {th }}$ century and until quite recently, medical microbiology was based on the assumption that a few microorganisms are pathogens while most are not. Although this binary view has now been strongly criticized, and considered untenable (Méthot and Alizon 2014), it is generally recognized that the interaction of the three factors of the host, pathogenic agent, and environment (plant disease triangle) determine whether a disease develops or not. Thus, plant stage of growth, pathogen virulence, and environmental changes result in a dynamic relationship over space and time (Agrios et al. 2005). Variations in any of the three interacting factors could significantly alter expected patterns of disease spread and development (Farber and Mundt 2017). Even if a host plant and a potential virulent pathogen are present in a certain area, serious disease epidemics will not occur unless the environment fosters their development (Bateman 1978; Keane and Kerr 1997; Agrios et al. 2005). Abiotic stresses can dramatically alter the outcome of plant-pathogen interactions and, depending on the pathosystem and stress intensity, the stress may enhance or reduce diseases. Even mild, episodic stresses can predispose plants to levels of pathogen inoculum that would not be damaging in the absence of the stress (Bostock et al. 2014). Environmental stresses also influence overall plant tolerance to insect pests (Louda and Collinge 1992).

The idea that a pathogenic organism is essentially a static or unchanging entity distinct from other types of microbes would mean that such a microorganism possessed an inherent capacity to cause disease in hosts. Pathogenicity is a dynamic feature of an interaction between a host and microbes as influenced by the environment (Agrios et al. 2005; Méthot and Alizon 2014). The role of beneficial or commensal microorganisms in plant health is now widely acknowledged, both in soil (especially the rhizosphere microbiome), and in leaves (the phyllosphere microbiome; Andrews and Harris 2000; Paszkowski 2006; Leveau 2019; Teixeira et al. 2019; Yu et al. 2019). Although knowledge of plant-plant and plant-microbe interactions has been greatly extended in recent years, the chemical communication leading to defense priming is not well-understood (Mhlongo et al. 2018) and highlights the need to further elucidate microbial functions and interactions (Toyota and Shirai 2018). Thus, two of the major questions remaining are "what makes a commensal or an opportunistic microorganism become pathogenic?" and "how do pathogenic microorganisms impact plant health?" Understanding the impacts of stresses on plant health is, therefore, important for obtaining optimum crop production efficiency. Stress is defined as "a sudden change in the environment that exceeds the organism's optimum to cause homeostatic imbalance which must be compensated for" (Kilian et al. 2012). Homeostasis is considered an underestimated focal point of ecology and evolution (Giordano 2013) although "cellular redox homeostasis in plants" is understood to be central to the plant stress defense system (Anjum et al. 2016). More generally, Eh and $\mathrm{pH}$ signaling and homeostasis should be regarded as key processes in many aspects of plant biology (Rengel 2002; Foyer and Noctor 2016) since plants function in a specific Eh-pH spectrum and rely on 
host and pathogen may be considered a key battlefield in determining the outcome of pathogen attack (Williams et al. 2011).

Indeed, redox potential $(\mathrm{Eh})$ and hydrogen potential $(\mathrm{pH})$ regulation (Eh- $\mathrm{pH}$, maintenance of extra- and intracellular redox states) are key to both plant-pathogen (bacteria, fungi, oomycetes, and viruses) and plant-animal pest (especially insects) interactions through:

i) upstream regulation by maintaining the plant unfavorable to pest or pathogen attacks: via development of physical barriers (wax, suberin, cutin, hardened cell walls, silica, etc.) or regulation of natural openings such as stomata (Chen and Gallie 2004; Foyer 2005; Liu et al. 2007; Pollard et al. 2008; Samuels et al. 2008; Pastor et al. 2013; Coskun et al. 2019);

ii) downstream regulation after pest or pathogen attack, mainly through oxygen burst by plants and responses of pathogens-pests (Mehdy 1994; Lamb and Dixon 1997; Kuzniak et al. 2005; Kuzniak 2010; Lehmann et al. 2015; Qi et al. 2016; González-Bosch 2018; Segal and Wilson 2018) to include

control of Systemic Acquired Resistance (SAR) and Induced Systemic Resistance (ISR) (Fobert and Després 2005; Spoel and Loake 2011; Frederickson Matika and Loake 2013) in a complex interaction with plant hormones (Srivastava et al. 2017).

In addition, sensing of the host plant by pests and pathogens can be influenced by the plant's Eh-pH state in different ways, including emission of volatiles (Wei et al. 2014), redox associated mechanisms as in parasitic weeds (Yoder 2001), osmotic changes, and alteration of magnetic and electric fields emitted by plants which are recognized by insects (Newland et al. 2008; Greggers et al. 2013; Clarke et al. 2013), nematodes (Shapiro-Ilan et al. 2012; Ilan et al. 2013) and oomycetes (van West et al. 2002).

Cook and Baker (1983) defined disease suppressive soils as soils in which either: i) the pathogen does not establish or persist, ii) the pathogen establishes but causes no damage or iii) the pathogen causes some damage but the disease becomes progressively less severe even though the pathogen persists in soil. Two types of soil suppressiveness are known: i) general suppression, which is due to nutrient status and activity of the total microbial biomass in soil and is not transferable between soils, and ii) specific suppression owing to the activity of individual or selected groups of microorganisms and is transferable (Weller et al. 2002; Schlatter et al. 2017). While soil suppressiveness is mainly derived from the biological functions of soils (Toyota and Shirai 2018; Steinberg et al. 2019; De Corato 2021), there is plenty of evidence showing the role of both biotic and abiotic factors in disease suppression (Schneider 1982). Chemical and physical components of soil, including $\mathrm{pH}$, organic matter and clay content, can operate in the suppression of plant diseases directly or indirectly through their impact on soil microbial activity (Smiley and Cook 1972; Chandrashekara et al. 2012).

The definition of soil health or quality generally includes a range of physical, chemical and biological soil properties, such as soil type, organic matter content, nutrient cycling, biological activity and soil structure, all of which impact and are impacted by soil Eh and pH (Van Bruggen and Semenov 2000; Cardoso et al. 2013; Moebius-Clune et al. 2017; Bünemann et al. 2018; Husson et al. 2018b). Methods developed to assess plant health based on the underlying stress level measured as chlorophyll fluorescence or other photo-oxidative stress 
markers (including photosynthetic pigments, Photosystem II efficiency, Reactive Oxygen Species -ROS-, reactive carbonyl species, antioxidant systems) are all related to Eh and pH (Husson et al. 2018a).

A previous interdisciplinary review provided evidence that $\mathrm{Eh}$ and $\mathrm{pH}$ are major drivers of soil-plantmicroorganism systems (Husson 2013). This review bridged different disciplines such as soil sciences, plant physiology and microbial ecology and proposed a conceptual framework for further studies of soil-plantmicroorganism functioning. The framework was based on the hypothesis that plants function physiologically within a specific internal Eh-pH range and that, along with microorganisms, they alter Eh and $\mathrm{pH}$ in the rhizosphere to ensure homeostasis at the cell level. Based on that review and subsequent works, we propose a conceptual model of soil-plant-microorganism system functioning driven by Eh and pH (Fig. 1):

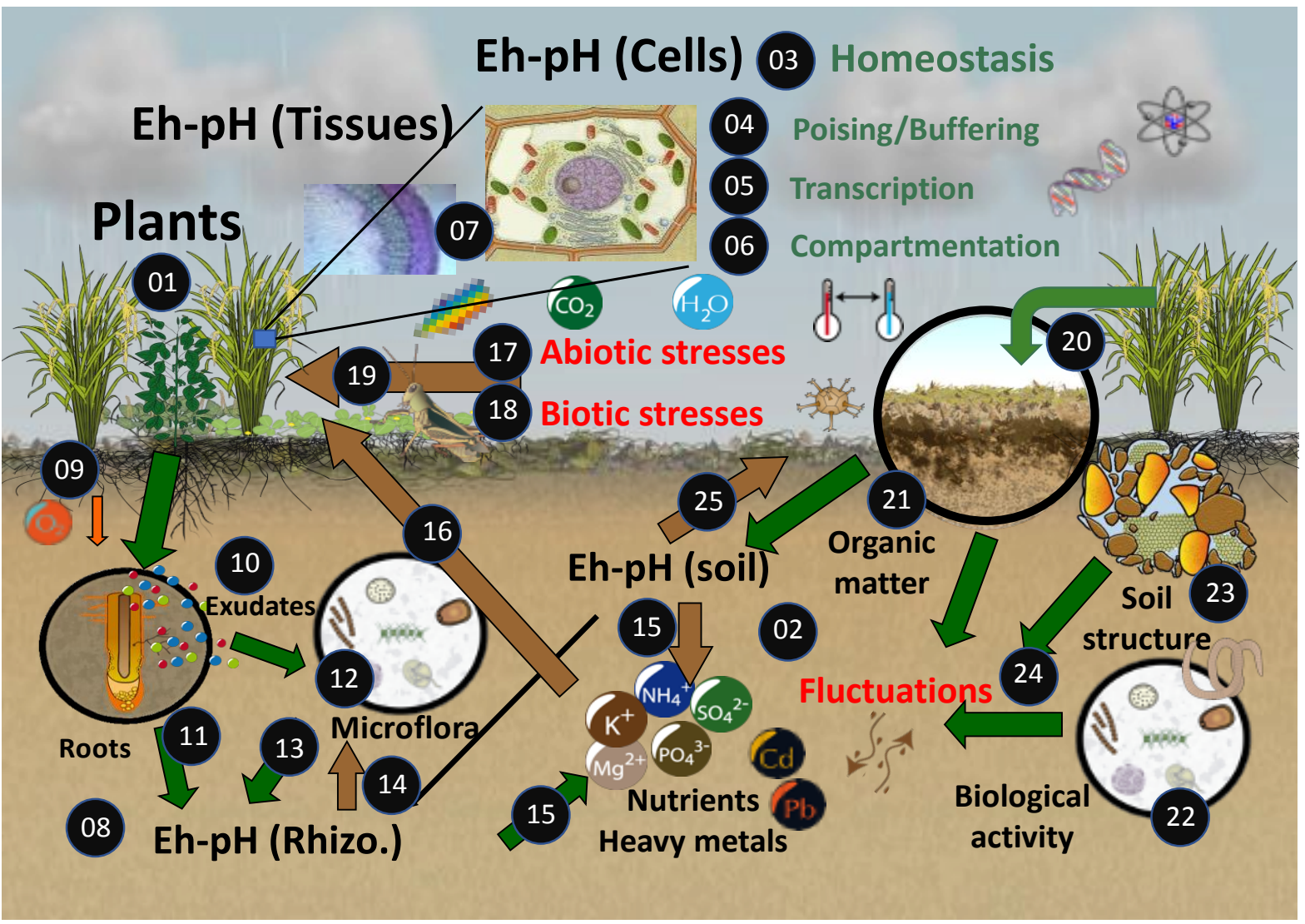

Fig. 1: The Eh-pH driven conceptual model of how the soil-plant-microorganism system could function to indicate the key role of dynamic maintenance of Eh-pH homeostasis for soil and plant health. Plants (01) grow in soil with highly fluctuating Eh-pH characteristics (02). To insure the necessary Eh-pH homeostasis at the cellular level (03), they regulate Eh and $\mathrm{pH}$ at short term through cascades of chemical and buffering reactions (04). When short-term buffering capacity is exceeded, there is a response at the transcript level (05). Eh-pH homeostasis is also sustained through metabolic compartmentation in the various organelles inside a cell that function at specific levels (06), and the cells evacuate the highly oxidized or reduced products from the cytoplasm through the cell walls (07). Another important process to achieve internal Eh-pH homeostasis is regulation of the external Eh-pH at the rhizosphere level (08). Under highly reduced (anaerobic) conditions, some plants (such as rice) have the ability to pump oxygen through aerenchyma cells to raise Eh in the 

exudates modify rhizosphere Eh-pH (11), stimulate and feed specific microorganisms (12), which further alter rhizosphere Eh-pH conditions (13). In return, soil, and especially rhizosphere, Eh-pH will largely determine the composition of the microflora (14) and the solubility and absorption of nutrients and heavy metals (15). Plant nutrition affects plant Eh-pH, especially nutrient deficiencies and toxic elements, which results in oxidative stress (16). Similarly, abiotic stresses (temperature, water, $\mathrm{CO}_{2}$, light, etc. (17) lead to oxidative stress in the plant which leads to higher susceptibility to pests and plant pathogens. These biotic stresses (18) also lead to oxidative stress in the plant (19). In the medium to long term, plant residues (20) feed the soil microbes, alter soil organic matter (21), determine biological activity and diversity (22) and influence soil structure (23). Via these interactions, soil pH is buffered towards neutral values and soil Eh is lowered and buffered (24). Finally, soil microbes and Eh affect the fate of soil organic matter by increasing mineralization and reducing humification under oxidized conditions (25).

Changes in Eh-pH levels in plants can result from interactions among a large range of factors (edaphic, climatic and biotic). In this model, the effects of multiple stresses induce oxidative stress in the plant and result in a specific Eh-pH state. Under favorable conditions, plants will be able to sustain their homeostasis through an efficient photosynthetic process which uses solar energy to produce energy rich-glucose by combining $\mathrm{CO}_{2}$ with $\mathrm{H}_{2}$ from water. Oxidative stresses linked to unfavorable conditions (extreme $\mathrm{pH}$, nutrient deficiency, $\mathrm{NO}_{3}{ }^{-}$ absorption, metal toxicity, reduction of $\mathrm{N}, \mathrm{Fe}, \mathrm{Mn}$, or S, pollution, low light, water stress, extreme temperatures, biotic stresses, etc.) require responses that represent an energy cost for the plant. The higher the stress, the higher the cost, creating a vicious circle where the more the plant spends energy to sustain cell homeostasis, the less energy it has to produce leaves; the smaller the leaf area, the lower the photosynthetic capacity; and the lower the photosynthesis, the lower the capacity to sustain Eh-pH homeostasis. When the various stresses overpass the plant capacity to sustain cell homeostasis, it leads to a strong imbalance that can cause severe consequences, as for example, increased susceptibility to pests and pathogens and ultimately plant death.

This paper proposes a novel conceptual framework of plant interactions with pests and pathogens that is based on the following hypotheses: soil and plant health are strongly related to Eh-pH homeostasis and plants become susceptible to pest and pathogen attacks when imbalanced Eh-pH conditions in plant compartments correspond to the specific Eh-pH conditions at which the various pests and pathogens thrive. The conceptual framework is based on four sub-hypotheses: are exposed to a range of environmental conditions that allow microbial persistence and utilization of present resources. Species-specific phenotypic characteristics determine if a species can be found in a certain ecological niche and how it interacts with its environment (Koch and Harnisch 2016), apoplast, cells, organelles etc.) constitute different Eh-pH niches, with temporal variations,

iv) Environmental (abiotic and biotic) stresses alter Eh-pH in these niches. 
188 Although redox regulation is also involved in plant-weed interactions, especially in parasitic weeds (Yoder 189 2001) and through redox-associated mechanisms for allelopathy (Downum and Rodriguez 1986; Cheng and 190 Cheng 2015), we excluded weeds from this review and limit it to only two kinds of pests (pathogens and insects or nematodes) for which Eh-pH interactions are better documented.

192 Furthermore, the detailed processes involved in maintenance of Eh-pH homeostasis at various scales in plant/soil/microorganisms systems are not the object of this review. Especially, the critical roles of transition metals in processes related to dynamic redox regulation are not considered here. However, we would like to simply stress that metals such as $\mathrm{Fe}, \mathrm{Mn}, \mathrm{Zn}, \mathrm{Cu}, \mathrm{Co}$, or Mo both regulate and are regulated by Eh-pH conditions and their homeostasis in the various plant compartments is crucial, especially in chloroplasts (Yruela 2013). Transition metals are involved in virtually all oxidation-reduction reactions through: i) physical processes, as their ability to accept or donate single electrons makes them able to overcome the spin restriction in oxidation by $\mathrm{O}_{2}$, in accordance with Pauli's principle (Halliwell and Gutteridge 1984); ii) chemical processes, exchanging electrons and protons with a ratio different than one as the $\mathrm{Fe}^{2+} / \mathrm{Fe}(\mathrm{OH})_{3}$ redox couple exchanging three protons for one electron, thus impacting the electrons-protons balance ( $p e+\mathrm{pH})$ in soils (Ponnamperuma 1972); and iii) biological processes, being essential constituents of molecules involved in redox processes as chlorophyll, cytochromes and enzymes as oxidases and hydrogenases (Halliwell and Gutteridge 1984; Yruela 2013). Maintenance of Eh-pH homeostasis should therefore be regarded as a dynamic process, insured by strong interactions between physical, chemical and biological processes and related to metal ions homeostasis. To support our underlying hypotheses, we : i) Provide an analysis of plant-pests (pests sensu lato that includes animal pests and pathogens) interactions from an Eh-pH perspective by reviewing the literature; ii) Report examples showing how development and attacks of pests are correlated with spatial and temporal variations in plant Eh-pH; iii) Propose evidence-based discussion of how Eh-pH homeostasis can provide a new perspective on plant health and help clarify the many Genotype x Environment x Management x Pest (G x E x M x P) interactions; iv) Explore correlations between spatio-temporal variability of Eh-pH and genotypic variations impacted by various abiotic and biotic stresses and plant susceptibility-tolerance-resistance to pests; v) Revisit mineral nutrition and plant-pest interactions from an Eh-pH perspective as well as pathogenicity and virulence; vi) Propose an original perspective on energy allocation and growth-defense tradeoff by plants based on the Eh$\mathrm{pH}$ homeostasis approach and finally; vii) We review how Eh-pH conditions in the rhizosphere are the results of multiple interactions between roots and microorganisms and propose the following hypothesis: that soil structure leading to diverse Eh-pH niches and hosting a high diversity of microorganisms, is the key determinant of a soil's disease suppressiveness.

\section{Eh-pH conditions at which pests can thrive}

221 Plant pathogens

222 Each organism has an optimal Eh-pH range for its development. Pathogens having a broad host range are able to

223 develop under a large range of Eh-pH conditions, as for instance Pseudomonas syringae (Morris et al. 2019).

224 However, most pathogens are adapted to specific hosts, and have a relatively narrow optimal range of Eh-pH in 225 which they are pathogenic (Rabotnova and Schwartz 1962). The Eh-pH conditions at which some plant 
pathogenic fungi and oomycetes can thrive are summarized in Table 1 while those for bacteria and viruses are reported in Table 2 .

Table 1. Optimal Eh-pH conditions at which key plant pathogenic fungi and oomycetes are pathogenic. Most fungal pathogens develop under both oxidized $(E h>400 \mathrm{mV})$ and acidic conditions. Necrotrophic fungi develop better in more acidic (and less oxidized) conditions than hemi-biotrophic and biotrophic fungi. A number of plant pathogenic fungi thrive in slightly acidic to alkaline conditions, as for example Gaeumannomyces, Verticillium, Colletotrichum sp. etc. Fungi developing in the apoplast develop at lower $p H$ than those growing in the phloem. Many oomycetes develop in less oxidized conditions than their fungal counterparts, in a wide range of $\mathrm{pH}$ although with large species-specific variations in optimal $\mathrm{pH}$. $\mathrm{pH}$ values in brackets indicate possible range of survival while na means non-available. These are only indications of the tendency of the main groups of pathogens. As large differences can exist between species, each pathogen should be characterized by its specific Eh-pH range of development and by its location in the plant.

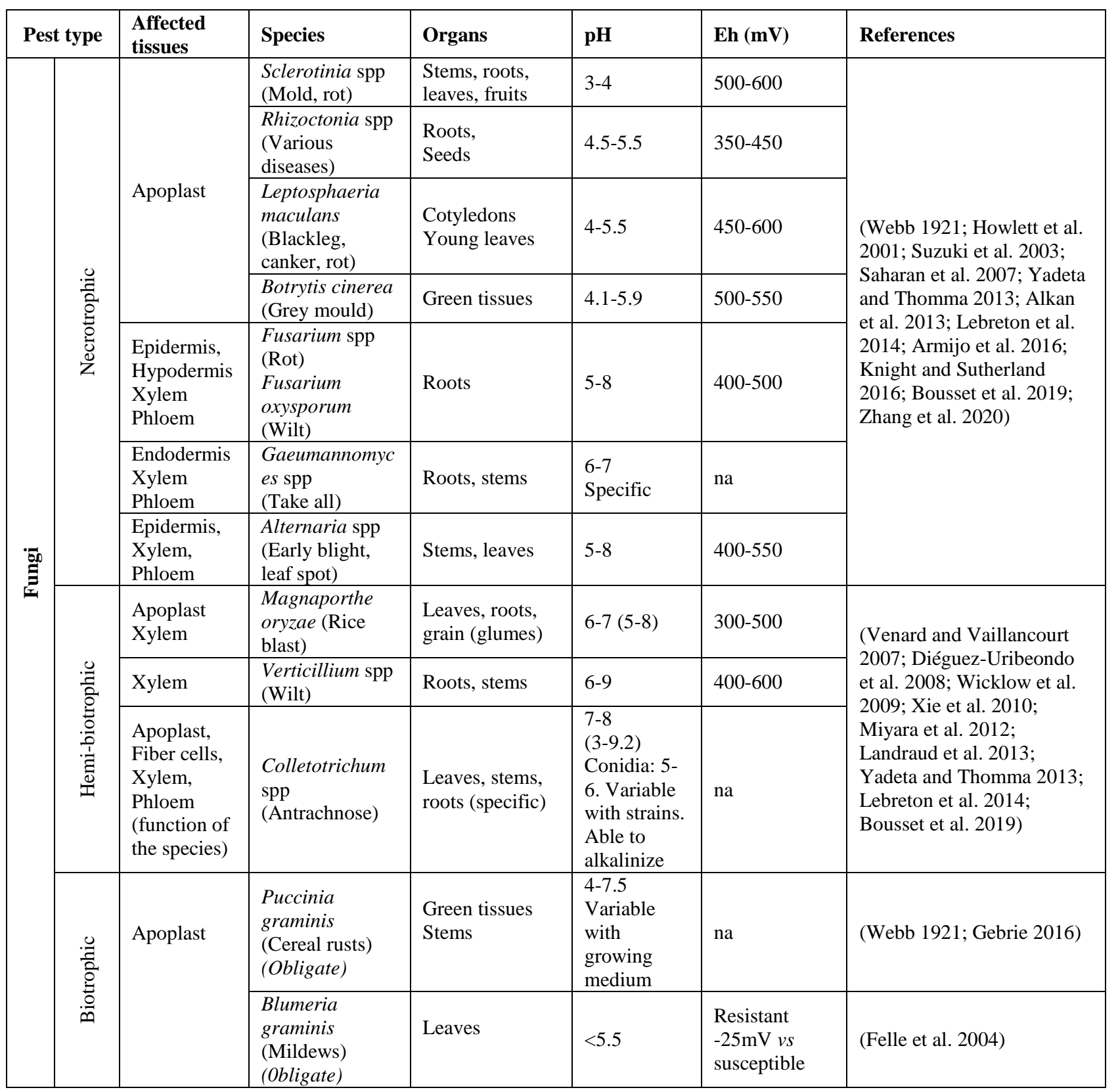




\begin{tabular}{|c|c|c|c|c|c|c|c|}
\hline & & \multirow[t]{2}{*}{ Epidermis } & $\begin{array}{l}\text { Ustilago maydis } \\
\text { (Smut) }\end{array}$ & Leaves & $\begin{array}{l}5.1-5.5 \\
\text { Strain } \\
\text { specific }\end{array}$ & na & (Geiser et al. 2014) \\
\hline & & & $\begin{array}{l}\text { Erysiphe } \\
\text { graminis } \\
\text { (Powdery } \\
\text { mildew) }\end{array}$ & Leaves & 5.6 & $265-325$ & $\begin{array}{l}\text { (Benada 1966; Arabi and } \\
\text { Jawhar 2002) }\end{array}$ \\
\hline \multirow{3}{*}{ 苞 } & 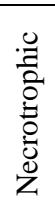 & $\begin{array}{l}\text { Epi- and } \\
\text { endodermis, } \\
\text { Apoplast, } \\
\text { Xylem, } \\
\text { Phloem }\end{array}$ & $\begin{array}{l}\text { Pythium spp } \\
\text { (Damping off) }\end{array}$ & $\begin{array}{l}\text { Seeds, roots, } \\
\text { stems }\end{array}$ & $\begin{array}{l}6-6.5 \\
(3-9) \\
\text { specific }\end{array}$ & $\begin{array}{l}\text { Using nitrate } \\
\text { Cathodo- } \\
\text { tactic }(P . \\
\text { aphadni- } \\
\text { dermatum })\end{array}$ & $\begin{array}{l}\text { (Van West et al. 2003; } \\
\text { Kong et al. 2009; Van } \\
\text { Buyten and Höfte 2013; } \\
\text { Krasnow and Hausbeck } \\
\text { 2017; Ah-Fong et al. 2019) }\end{array}$ \\
\hline & 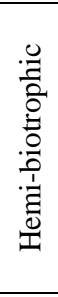 & $\begin{array}{l}\text { Apoplast, } \\
\text { Xylem }\end{array}$ & $\begin{array}{l}\text { Phytophthora } \\
\text { spp } \\
\text { (Mildew) }\end{array}$ & $\begin{array}{l}\text { Roots, tubers, } \\
\text { leaves }\end{array}$ & $\begin{array}{l}6-6.5 \\
\text { Specific } \\
P . \text { citricola: } \\
9 P . \\
\text { tropicalis: } 5 \\
P . \\
\text { palmivora: } 4 \\
-6 \\
\end{array}$ & $\begin{array}{l}<350 \mathrm{mV}(P h . \\
\text { infestans) } \\
\text { Using amino- } \\
\text { acids Anodo- } \\
\text { tactic }(P . \\
\text { palmivora) }\end{array}$ & $\begin{array}{l}\text { (Morris et al. 1995; } \\
\text { Simpfendorfer et al. 2001; } \\
\text { Van West et al. 2003; } \\
\text { Benada 2012; Ah-Fong et } \\
\text { al. 2019) }\end{array}$ \\
\hline & 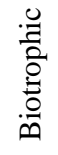 & Apoplast & $\begin{array}{l}\text { Albugo candida } \\
\text { (White rust) }\end{array}$ & Green tissues & $\begin{array}{l}6.5 \\
(3.5-9.5)\end{array}$ & na & (Endo and Linn 1960) \\
\hline
\end{tabular}

241 Table 2. Some Eh-pH conditions where various types of plant pathogenic bacteria and viruses can develop.

242 Many plant pathogenic bacteria grow under more reduced (lower Eh) conditions than their fungal counterparts, 243 in alkaline or slightly acidic plants or plant parts. These conditions are met in reduced (anaerobic) soils, and 244 correspond to relatively oxidized plants as nutrient balanced plants are reduced (pe $+p H<10)$. Viruses develop under both reduced and alkaline conditions, that also correspond to conditions found in reduced soils, but in strongly oxidized plants as the phloem is buffered at very low Eh in nutrient balanced plants. The listed Eh-pH

247 values are indicative of where microorganisms are pathogenic on plants although some of them (notably Gram-

248 negative bacteria) can thrive under different Eh-pH conditions, especially in reduced soil conditions for 249 bacteria, and then become pathogenic when conditions become more oxidized.

250 Aerobic conditions correspond to pe+pH >10 according to Rabotnova and Schwartz (1962). pe+pH is 251 equivalent to the chemical notion of $\mathrm{rH}_{2}$ or to correct Eh to $\mathrm{pH} 7$, which better characterizes oxidation in 252 organic chemistry than Eh alone. At $25^{\circ} \mathrm{C}$, pe $+p H=E h(V) / 0.059+p H$. Electrical neutrality corresponds to $253 p e+p H=14$ or Eh@pH7=402mV (Husson et al. 2016).

\begin{tabular}{|c|c|c|c|c|c|c|c|}
\hline \multicolumn{2}{|c|}{ Pest type } & $\begin{array}{c}\text { Affected } \\
\text { tissues }\end{array}$ & Species & Organs & pH & $\begin{array}{l}\text { Oxidation } \\
(p e+p H)\end{array}$ & References \\
\hline \multirow{3}{*}{ 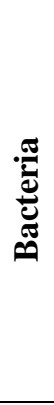 } & \multirow{3}{*}{ 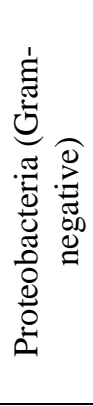 } & \multirow{3}{*}{ Apoplast } & $\begin{array}{l}\text { Pseudomonas } \\
\text { syringae }\end{array}$ & \multirow{3}{*}{$\begin{array}{l}\text { Leaves, } \\
\text { roots, } \\
\text { seedlings, } \\
\text { Seeds }\end{array}$} & $\begin{array}{l}\text { Large range. } \\
\text { Apoplastic } \\
\text { alkalization } \\
\text { induced } \\
\text { lesions }\end{array}$ & $\begin{array}{l}\text { Oxic and } \\
\text { microoxic = } \\
\text { aerobic and } \\
\text { facultative } \\
\text { anaerobic }\end{array}$ & \multirow{3}{*}{$\begin{array}{l}\text { (Rabotnova and } \\
\text { Schwartz 1962; } \\
\text { Gour et al. 2000; } \\
\text { Bové and Garnier } \\
\text { 2003; } \\
\text { Gnanamanickam } \\
\text { 2006; Hogenhout } \\
\text { and Loria 2008; } \\
\text { Bueno et al. 2012; } \\
\text { Yadeta and }\end{array}$} \\
\hline & & & $\begin{array}{l}\text { Xanthomonas } \\
\text { spp }\end{array}$ & & $5-9$ & Aerobic & \\
\hline & & & Ralstonia & & $7-8$ & Aerobic & \\
\hline
\end{tabular}




\begin{tabular}{|c|c|c|c|c|c|c|}
\hline & & solanacearum & & & & $\begin{array}{l}\text { Thomma 2013; } \\
\text { Geilfus et al. } \\
\text { 2020) }\end{array}$ \\
\hline & \multirow{2}{*}{ Apoplast, } & Erwinia spp & $\begin{array}{l}\text { Leaves, } \\
\text { fruits, tubers }\end{array}$ & $\begin{array}{l}7.5 \\
(5-9) \\
\text { Shifts }>8 \\
\text { upon } \\
\text { infection }\end{array}$ & $\begin{array}{l}\text { Facultative } \\
\text { anaerobic, } \\
\text { fermentative }\end{array}$ & \multirow{2}{*}{$\begin{array}{l}\text { (Nachin and } \\
\text { Barras 2000; } \\
\text { Shrestha et al. } \\
\text { 2005; Matthysse } \\
\text { 2006; Bueno et al. } \\
\text { 2012; Hwang et } \\
\text { al. 2017; Wang et } \\
\text { al. 2018) }\end{array}$} \\
\hline & & $\begin{array}{l}\text { Agrobacterium } \\
\text { tumefaciens }\end{array}$ & $\begin{array}{l}\text { Roots, } \\
\text { stems, trunks }\end{array}$ & 5.5 & $\begin{array}{l}\text { Aerobic } \\
\text { Able to } \\
\text { respire } \\
\text { nitrogen } \\
\text { oxides }\end{array}$ & \\
\hline & $\begin{array}{l}\text { Xylem } \\
\text { limited }\end{array}$ & $\begin{array}{l}\text { Xylella } \\
\text { fastidiosa }\end{array}$ & Leaves & $6.5-6.9$ & Aerobic & $\begin{array}{l}\text { (Wells et al. } \\
\text { 1987) }\end{array}$ \\
\hline & \multirow[b]{2}{*}{$\begin{array}{l}\text { Phloem } \\
\text { limited }\end{array}$} & $\begin{array}{l}\text { Candidatus } \\
\text { Liberibacter } \\
\text { crescens }\end{array}$ & \multirow[b]{2}{*}{$\begin{array}{l}\text { Leaves, } \\
\text { roots, } \\
\text { tubers }\end{array}$} & $5.8-6.8$ & $\begin{array}{l}\text { Strictly } \\
\text { aerobic }\end{array}$ & \multirow{2}{*}{$\begin{array}{l}\text { (Haapalainen } \\
\text { 2014; Bendix and } \\
\text { Lewis 2018; } \\
\text { Cruz-Munoz et al. } \\
\text { 2019; Molki et al. } \\
\text { 2019) }\end{array}$} \\
\hline & & $\begin{array}{l}\text { Candidatus } \\
\text { Liberibacter } \\
\text { asiaticus }\end{array}$ & & $\begin{array}{l}\text { Neutrophilic } \\
\text { Alkalization } \\
\text { of } \\
\text { hemolymph } \\
\text { to } 8.1\end{array}$ & $\begin{array}{l}\text { Micro- } \\
\text { aerophilic } \\
\text { Facultative } \\
\text { aerobic }\end{array}$ & \\
\hline 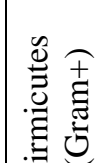 & $\begin{array}{l}\text { Phloem } \\
\text { limited }\end{array}$ & $\begin{array}{l}\text { Candidatus } \\
\text { Phytoplasma } \\
\text { Spiroplasma }\end{array}$ & $\begin{array}{l}\text { Leaves, } \\
\text { roots }\end{array}$ & 6 & $\begin{array}{l}\text { Micro- } \\
\text { aerophilic }\end{array}$ & \multirow{2}{*}{$\begin{array}{l}\text { (Wissenschafts et } \\
\text { al. 1999; Bové } \\
\text { and Garnier 2003; } \\
\text { Hogenhout and } \\
\text { Loria 2008; Jha } \\
\text { and Sonti 2009; } \\
\text { Sen et al. 2015; } \\
\text { Bendix and Lewis } \\
\text { 2018) }\end{array}$} \\
\hline 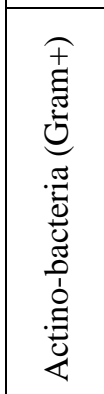 & $\begin{array}{l}\text { Xylem } \\
\text { and } \\
\text { apoplast }\end{array}$ & $\begin{array}{l}\text { Clavibacter } \\
\text { michiganensis } \\
\text { Corynebacteriu } \\
\text { m sepedonicum }\end{array}$ & $\begin{array}{l}\text { Leaves, } \\
\text { seed, roots, } \\
\text { tubers }\end{array}$ & $\begin{array}{l}7-8 \text { in } \\
\text { culture } \\
\text { Up to } 5 \text { in } \\
\text { xylem } \\
\text { Acidification } \\
\text { of } \\
\text { extracellular } \\
\text { pH to } 4.5 \text { in } \\
\text { Potato }\end{array}$ & Aerobic & \\
\hline \multirow{3}{*}{ 包 } & \multirow[b]{2}{*}{$\begin{array}{l}\text { Phloem } \\
\text { Epidermi } \\
\text { s cells }\end{array}$} & $\begin{array}{l}\text { Tomato Spotted } \\
\text { Wilt Virus }\end{array}$ & Leaves & $\begin{array}{l}7 \\
(>6 \text { and }<9)\end{array}$ & $<200 \mathrm{mV}$ & \multirow{3}{*}{$\begin{array}{l}\text { (Best and Samuel } \\
\text { 1936; Best 1968; } \\
\text { Opalka et al. } \\
\text { 1998; Brugidou et } \\
\text { al. 2002; } \\
\text { Steinmetz et al. } \\
\text { 2006; Zechmann } \\
\text { et al. 2007; Király } \\
\text { et al. 2008; } \\
\text { Clemente-Moreno } \\
\text { et al. 2013; Gillet } \\
\text { et al. 2013; Liao } \\
\text { et al. 2015; Wilts } \\
\text { et al. 2015; } \\
\text { Berthelot et al. } \\
\text { 2019) }\end{array}$} \\
\hline & & \multicolumn{2}{|c|}{$\begin{array}{c}\text { Various viruses (Tobacco } \\
\text { Mosaic Virus, Cowpea Mosaic } \\
\text { Virus, Plum Pox Virus, Turnip } \\
\text { Mosaic Virus, etc.) }\end{array}$} & $\begin{array}{l}\text { Swollen at } \\
\text { high pH } \\
\text { Reduced by } \\
\text { low pH }\end{array}$ & $\begin{array}{c}\text { Controlled } \\
\text { by } \\
\text { antioxidant, } \\
\text { increased by } \\
\text { ROS } \\
\text { Transmissio } \\
\mathrm{n} \text { activation } \\
\text { is operated } \\
\text { by a redox } \\
\text { switch }\end{array}$ & \\
\hline & $\begin{array}{l}\text { Phloem } \\
\text { and } \\
\text { xylem } \\
\text { Epidermi } \\
\text { s cells }\end{array}$ & $\begin{array}{l}\text { Rice Yellow } \\
\text { Mottle Virus }\end{array}$ & $\begin{array}{l}\text { Leaves, } \\
\text { stems }\end{array}$ & $\begin{array}{l}\text { Swollen, } \\
\text { unstable at } \\
\text { basic pH in } \\
\text { cytosol (7.5) } \\
\text { Compact, } \\
\text { stable at } \\
\text { acidic pH in } \\
\text { vacuoles (5) }\end{array}$ & $\begin{array}{c}\text { Favored by } \\
\mathrm{H}_{2} \mathrm{O}_{2}\end{array}$ & \\
\hline
\end{tabular}




\section{Insect pests}

258 Although it is well-known that insect pest interactions with plants are affected by both regulation and balance of $259 \mathrm{pH}$ (Harrison 2001), and by redox signaling (Zebelo and Maffei 2015), little is known about the influence of the combined Eh-pH levels (reflected in pe+pH) of the plant parts that insects feed upon.

The redox state of the apoplast exerts a strong influence on the extent of the plant response to aphid infestation in terms of altered cell wall composition and nutritional quality (Rasool et al. 2017). Eh-pH conditions affect plant digestibility by insects, and redox active components such as phenols are regarded as antifeedant, digestibility reducers and toxic (Fürstenberg-Hägg et al. 2013; Usha Rani and Pratyusha 2013; Napoleão et al. 2017). The Eh-pH in insect intestinal tracts is related to digestive enzymes and reflects different digestive strategies. The effects of plant allelochemicals, especially phenols, on insect herbivores are influenced by gut redox conditions. Therefore, the regulation of gut redox conditions is an important adaptation strategy of insect herbivores to the plant chemical defenses that must be included in the analysis of plant-insect interactions (Appel and Martin 1990). Herbivores may have multiple strategies to deal with foliar phenolics such as a "reducing strategy" in which reducing conditions in the gut prevent phenolic oxidation, and an "oxidative or polymerization strategy" in which phenolics are oxidized and rapidly polymerized. Herbivores feeding on foliage with a high concentration of readily oxidized and polymerized phenolics and low concentration of nutrients (e.g., many trees) may use the oxidative polymerization strategy. Conversely, herbivores feeding on foliage with a low concentration of phenolics but high concentration of nutrients for reducing potential (e.g., many herbs) may employ the reducing strategy (Appel 1993). Saprophytic larvae of Penthetria holosericea, which feed selectively on decomposed leaves and their own microbe-rich faeces, present very alkaline $(\mathrm{pH}>11)$ conditions with moderately low Eh $(230 \mathrm{mV})$ and thus, have a high pe+pH $(>15)$ in the midgut. These conditions differ fundamentally from those of detritivorous and humivorous insects which host a highly active, fermentative microbiota in their alkaline midgut or hindgut compartments (Šustr et al. 2014).

280 In a study of Lepidopteran larvae, midgut $\mathrm{pH}$ of Helicoverpa zea, Heliothis virescens and Hyphantria cunea (Noctuidae) revealed significant differences between insect species, but no host plant effect (geranium, cotton, clover or soybean), since all were strongly alkaline at pH 9.3 to 10.6 (Johnson and Felton 1996a). In contrast, midgut Eh was influenced by both insect and host plant species. Midguts of larvae feeding on clover and soybean had more positive potentials, with redox values about $100 \mathrm{mV}$ higher than those of larvae feeding on geranium. In this interaction, much of the variation in midgut redox conditions was due to the redox activity of host plant chemicals at the alkaline pH of the gut (Johnson and Felton 1996a).

287 Midgut Eh-pH, in relation to plant Eh-pH, therefore, can help discriminate insects based on their feeding mode and capacity to cope with an oxidized diet. Adults or nymphs of sucking insects preferentially feed on plant parts at neutral to basic pH, e.g. the phloem (Giaquinta 1977; Gerendás and Schurr 1999). They dislike strongly reduced plants or plant parts that are rich in phenols and ascorbic acid (Farkas et al. 1960). It is interesting that these insects often are vectors of viruses that require high $\mathrm{pH}$.

292 Also, a lower level of ROS and a higher antioxidant potential in the adult than in the larval midgut indicate stage

293 specificity in the management of oxidative stress as reported for Leptinotarsa decemlineata (Coleoptera, 294 Chrysomelidae), the Colorado Potato Beetle, which has a midgut with low pH of 5.38 to 6.30, and pe+pH of 
5.93 to 6.95 (Krishnan et al. 2007). Phytophagous Lepidopteran larvae have a higher midgut pH, with a low Eh and $\mathrm{pe}+\mathrm{pH}$ for a specialist such as Manduca sexta with a $\mathrm{pH}$ of 8.0 to 9.3 , an Eh of -188 to $-88 \mathrm{mV}$ and a pe+pH of 5.8 to 6.8. In contrast, generalists have a high $\mathrm{Eh}$ and pe+pH, for example, Lymantria dispar with a $\mathrm{pH}$ of 7.9 to 8.2, an Eh: +214 to $+238 \mathrm{mV}$ and a pe+pH of 11.6 to 12.2. Another example is Papilio glaucus with a $\mathrm{pH}$ of 9.8 to 10.1, an Eh of +17 to $+57 \mathrm{mV}$ and a pe+pH of 10.4 to 11.0 (Appel and Martin 1990).

Regarding phytophagous insects, little is known about the Eh-pH levels of the plant parts they feed upon. Johnson and Felton (1996b) reported midgut $\mathrm{Eh}$ and $\mathrm{pH}$ values for 13 Lepidopteran, two Coleopteran, one Orthopteran and one Isopteran species feeding on natural host plants or plant-derived foods. Table 3 reports new information published in the literature.

Table 3. Eh-pH physicochemical status of some phytophagous-saprophagous insect midguts (based on literature published following the review by Johnson and Felton 1996b).

\begin{tabular}{|c|c|c|c|c|c|}
\hline Insect species & $\begin{array}{l}\text { Order \& } \\
\text { Family }\end{array}$ & Food source & $\begin{array}{l}\text { Midgut Redox } \\
\text { (Eh: } \mathbf{m V})\end{array}$ & $\begin{array}{l}\text { Midgut } \\
\text { pH }\end{array}$ & References \\
\hline $\begin{array}{l}\text { Leptinotarsa } \\
\text { decemlineata }\end{array}$ & $\begin{array}{l}\text { Coleoptera; } \\
\text { Chrysomelidae }\end{array}$ & $\begin{array}{l}\text { Leaves- } \\
\text { mesophylla }\end{array}$ & $\begin{array}{l}\text { Adults: }-177 \text { to } 0 \\
\text { Last instar larvae: } \\
+32 \text { to }+38\end{array}$ & $\begin{array}{l}\text { Adults: } \\
5.37-6.4 \\
\text { Last instar } \\
\text { larvae: } \\
5.38-6.30\end{array}$ & $\begin{array}{l}\text { (Krishnan et } \\
\text { al. 2007, } \\
\text { 2009) }\end{array}$ \\
\hline $\begin{array}{l}\text { Melolontha } \\
\text { melolontha }\end{array}$ & $\begin{array}{l}\text { Coleoptera: } \\
\text { Scarabaeidae }\end{array}$ & Roots & +220 to +340 & $7.9-8.2$ & $\begin{array}{l}\text { (Egert et al. } \\
2005)\end{array}$ \\
\hline $\begin{array}{l}\text { Pachnoda } \\
\text { ephipppiata }\end{array}$ & $\begin{array}{l}\text { Coleoptera: } \\
\text { Scarabaeidae }\end{array}$ & Soil organic matter & -190 to +180 & $8.4-10.7$ & $\begin{array}{l}\text { (Lemke et al. } \\
2003)\end{array}$ \\
\hline $\begin{array}{l}\text { Pachnoda } \\
\text { marginata }\end{array}$ & $\begin{array}{l}\text { Coleoptera: } \\
\text { Scarabaeidae }\end{array}$ & Soil organic matter & -200 to -100 & $9.5-11.7$ & $\begin{array}{l}\text { (Cazemier et } \\
\text { al. 1997, } \\
2003)\end{array}$ \\
\hline $\begin{array}{l}\text { Penthetria } \\
\text { holosericea }\end{array}$ & $\begin{array}{l}\text { Diptera: } \\
\text { Bibionidae }\end{array}$ & Soil organic matter & +20 to +60 & 11 & $\begin{array}{l}\text { (Šustr et al. } \\
\text { 2014) }\end{array}$ \\
\hline Agrotis ipsilon & $\begin{array}{l}\text { Lepidoptera; } \\
\text { Noctuidae }\end{array}$ & Stem-collar & +171 to +250 & $9-9.75$ & $\begin{array}{l}\text { (Ellakwa } \\
\text { 2014) }\end{array}$ \\
\hline $\begin{array}{l}\text { Spodoptera } \\
\text { littoralis }\end{array}$ & $\begin{array}{l}\text { Lepidoptera; } \\
\text { Noctuidae }\end{array}$ & $\begin{array}{l}\text { Leaves- } \\
\text { mesophylla }\end{array}$ & -131 to +370 & $8.2-8.8$ & $\begin{array}{l}\text { (Krishnan and } \\
\text { Kodrík 2006) } \\
\end{array}$ \\
\hline $\begin{array}{l}\text { Acrididae }(23 \\
\text { spp) }\end{array}$ & $\begin{array}{l}\text { Orthoptera; } \\
\text { Acrididae }\end{array}$ & $\begin{array}{l}\text { Leaves- } \\
\text { mesophylla }\end{array}$ & +179 to +327 & $5.90-7.33$ & $\begin{array}{l}\text { Appel and } \\
\text { Joern 1998) }\end{array}$ \\
\hline $\begin{array}{l}\text { Reticulitermes } \\
\text { flavipes }\end{array}$ & $\begin{array}{l}\text { Isoptera: } \\
\text { Rhinotermitidae }\end{array}$ & Soil organic matter & +80 to +200 & 6.5 to 7.0 & $\begin{array}{l}\text { (Ebert and } \\
\text { Brune 1997) }\end{array}$ \\
\hline $\begin{array}{l}\text { Cubitermes } \\
\text { ugandensis }\end{array}$ & $\begin{array}{l}\text { Isoptera: } \\
\text { Termitidae }\end{array}$ & Soil organic matter & +350 to 400 & 6.0 & $\begin{array}{l}\text { (Kappler and } \\
\text { Brune 2002) }\end{array}$ \\
\hline
\end{tabular}
mainly for insects whose body size allows gut dissection (e.g. Lepidoptera, Orthoptera, and some Coleoptera, particularly Scarab beetles). Although Isoptera have a small body size there is interest in studying their digestive processes because they involve symbiotic microbiota (in the hindgut). Still, there are some reservations about the accuracy of Eh measurements for the latter (Eutick et al. 1976; Veivers et al. 1980; Brune et al. 1995). In

314 addition, information is often lacking as to whether redox potentials indicated in these studies are Eh (according to the Standard Hydrogen Electrode) or potentials measured via the reference electrode (Ag- $\mathrm{AgCl}$ or calomel). Information on Eh-pH midgut conditions is also missing for species whose diet differs between immature and 
decemlineata is the only species studied for both adults and larvae even though they both feed on the same plant organs. Nevertheless, the positioning of this species on the Eh-pH map is consistent with that of E. varivestis (Murdock et al. 1987; Johnson and Felton 1996b; Krishnan et al. 2009). The positioning of the 23 species of Orthoptera is also consistent with that of L. migratoria (Bignell 1984; Johnson and Felton 1996b; Appel and Joern 1998).

Overall, it is difficult to draw overarching conclusions of phytophagous-saprophytic insects based on their taxonomy, feeding-style or developmental stage (an exception is Colorado beetle chewing-biting larvae and adults). This is due either to a complete lack of information on piercing-sucking species, independent of adults or nymphs or a partial lack of information on chewing-biting species for which diet differs between immature and adult stages: chafer beetles (Pachnoda spp.) are soil saprophytes at the larval stage and aerial herbivores at the adult stage; cockchafers (M. melolontha) or blackbeetles (Oryctes nasicornis) are root-feeding or saprophytic as larvae but aerial herbivores as adults. For example, information on chewing-biting Lepidopteran caterpillarsworms is available only for larvae (since adults generally do not feed on plant parts) while the information is available only for adults for chewing-biting grasshoppers.

Gastropods and nematodes

Charrier and Brune (2003) showed that two phyllophageous species of starved helicid snails (Gastropoda and Pulmonata), (Helix pomatia and Cornu aspersum, syn. Helix aspersa) had a $\mathrm{pH}$ increasing from the crop (an expanded portion of the alimentary tract used for the storage of food prior to digestion) to the distal intestine of pH 6.4 and 7.4, respectively. In the saprophagous Elona quimperiana, the pH along the gut axis remained acidic (5.1-6.6). Oxygen was not detected in the gut lumen of any of these species to highlight anaerobic conditions. This clearly illustrates that the morpho-anatomical differentiation of the intestinal tract corresponds to different physicochemical microenvironments. The increasing alkalinity along the gut should have repercussions for the microbial communities colonizing the intestine. Intestinal microbiota, in turn, may cause changes in the $\mathrm{pH}$ of the host tissue during anaerobiosis (Pörtner 1987; Charrier and Brune 2003).

Nematodes perceive and respond to $\mathrm{pH}$ and redox potential gradients in the soil or rhizosphere (Hua et al. 2020). Detrimental nematodes seem to require oxidized conditions as suggested by the negative impact of reduced conditions during anaerobic soil disinfection (Di Gioia et al. 2016; Browne et al. 2018), the efficient antioxidant defense systems of spring barley in response to stress induced by Heterodera filipjevi (Labudda et al. 2020), the high nematicide activity of reduced organic acids (Oka 2010), or the requirement of peroxiredoxins from

350 Meloidogyne incognita for its successful development (Dubreuil et al. 2011). Many plant pathogenic nematodes such as Heterodera glycines, Meloidogyne incognita or M. hapla, thrive at low (4.5 to 5.5) pH (Hua et al. 2020). The greatest numbers of Pratylenchus alleni colonized soybean roots at $\mathrm{pH}$ 6.0. Hoplolaimus galeatus and members of the Tylenchinae-Psilenchinae survived best at soil $\mathrm{pH}$ 6.0, while numbers of the Dorylaimidea were greatest at both pH 6.0 and 8.0. Non-stylet nematodes (Rhabditidae and Cephalobidae) were recovered in greater numbers from $\mathrm{pH} 8.0$ soil (Burns 1971). 

suggested that the distribution of the rust could be driven more by differences in host susceptibility than by propagule dispersal. Benada (2017) hypothesized that Eh and pH are major players in plant physiology and pathogen resistance in order to explain the variable changes in resistance that occur during ontogeny of the host and environment that involve: i) the disease gradients on a plant, ii) the evolution of susceptibility of organs during ontogeny and growth, and iii) the difference in resistance of individual plant cells and relatively swift changes of its resistance within a couple of hours. From an evolutionary point of view, the circadian rhythmic cell is a hydro-electro-chemical oscillator driven or synchronized by sunlight with a temporal compartmentation of metabolism and a network of metabolic sequences to compensate for oxidative stress (Wagner et al. 2000). It is, therefore, not surprising to observe a strong spatial and temporal variability of Eh and $\mathrm{pH}$ in plants.

Plants have five key nutrient tissues, namely the phloem, xylem, leaf apoplast, root apoplast, and cellular organelles that serve as nutrient reservoirs. Each of these are the target of certain pathogens and pests (Fatima and Senthil-Kumar 2015). The nutrient content in these tissues differ in types of minerals and carbon sources (sugars, amino- and organic acids, and organic alcohols) (Fatima and Senthil-Kumar 2015), all of which affect Eh or $\mathrm{pH}$. Eh and $\mathrm{pH}$ have been recognized as important factors defining ecological niches for microorganisms (Köpke et al. 2005; Vartoukian et al. 2010; Cardinale 2011; Jones et al. 2015; Koch and Harnisch 2016). The difference in Eh-pH between roots and shoots, as well as between apoplast, xylem and phloem, can therefore be used to characterize Eh-pH niches.

\section{Eh-pH niches: Roots vs shoots or grains}

380 The assessment of redox state based on ratios of ASC/DHA (reduced vs. oxidized AsA) or GSH/GSSG (reduced vs. oxidized Glutathione) ratios logically shows that roots (i. e. non photosynthetic organs) are more oxidized than leaves (i.e. photosynthetic organs) in maize (Ahmad et al. 2016), soybean (Borella et al. 2019), sunflower (Ortega et al. 2017), onion (García et al. 2020) and poplar (Morabito and Guerrier 2000). Roots show tremendous variability in rhizospheric-apoplastic $\mathrm{pH}$, especially in relation to nitrogen mineral nutrition. There is strong acidification related to $\mathrm{NH}_{4}{ }^{+}$absorption and pronounced alkalization related to $\mathrm{NO}_{3}{ }^{-}$absorption (Marschner et al. 1986). Masiello et al. (2008) measured a higher carbon oxidation state in maize grains than in maize stover. Internal oxygen concentrations are lower within bulky storage organs such as fruits (apple, banana) or tubers than other tissues. This results in different oxygen gradients within growing potato tubers which have a very low oxygen level in the center of the tuber (Geigenberger 2003).

Leaf Eh-pH also has high spatial variability. Husson et al. (2018a) plotted the spatial distribution of Eh and pH in rice plants and showed that average leaf $\mathrm{pH}$ decreased from younger leaves (located on the upper part of the canopy) to the older ones (located on the lower part of the canopy). The youngest leaves had the highest Eh values, which were negatively correlated with their length (the shorter the leaf, the higher the Eh value). The last fully expanded leaf had the lowest Eh, and Eh of mature leaves increased with leaf age, with the lowest leaves 
in the second upper leaf of wheat and barley during stem elongation, while the lowest value was in the top leaf when the ear appeared in wheat. In dicotyledons such as bean (Phaseolus vulgaris), 3-days-old intact plantlets had greater antioxidant protection by antioxidant proteins (thioredoxin, glutathione reductase, peroxiredoxin) than 9-day-old individual cotyledons (Karmous et al. 2017). Overall, while the mean Eh-pH measured at leaf level or the redox state at leaf or root level provides useful information on plant health (Husson et al. 2018a), this knowledge does not provide information on intra-organ variability of Eh and $\mathrm{pH}$. Nevertheless, such information is needed since the various types of pathogens or pests do not all colonize or feed on the same plant organs.

\section{Eh-pH niches within organs: phloem, xylem and apoplast}

Eh-pH conditions in phloem, xylem and apoplast are summarized in Table 4. The phloem is strongly buffered at high $\mathrm{pH}$ and low Eh. In contrast, the xylem $\mathrm{pH}$ is acidic but its Eh-pH varies relative to external conditions, especially soil Eh-pH. The apoplast is acidic and more oxidized but apoplast Eh-pH varies relative to tissue age and function (elongating tissues are more acidic) and is poorly buffered.

Table 4. Homeostasis level, buffering capacity and processes involved in Eh-pH regulation in phloem, xylem and

\begin{tabular}{|c|c|c|c|c|}
\hline Location & $\begin{array}{l}\text { pH- } \\
\text { Eh }\end{array}$ & $\begin{array}{l}\text { Homeostasis } \\
\text { Buffering } \\
\text { capacity }\end{array}$ & Physiological processes & References \\
\hline \multirow[b]{2}{*}{ Phloem } & $\mathrm{pH}$ & $\begin{array}{l}7.5 \text { to } 8.5 \\
\text { Strongly } \\
\text { buffered } \\
5.0 \text { to } 6 \text { in } \\
\text { Citrus }\end{array}$ & $\begin{array}{l}\text { High } \mathrm{pH} \text { needed for active transport system } \\
\text { coupling sucrose translocation across the } \\
\text { plasma membrane (phloem loading) to the } \\
\text { proton motive force generated by the } \mathrm{H}^{+}- \\
\text {pumping ATPase } \\
\text { Phloem loading of sucrose is } \mathrm{pH} \text {-dependent, } \\
\text { and is markedly inhibited at an apoplast } \mathrm{pH} \text { of } \\
8 \text { compared to pH5 }\end{array}$ & $\begin{array}{l}\text { (Giaquinta 1977; Bush } \\
\text { 1992; Gerendás and } \\
\text { Schurr 1999; Hijaz and } \\
\text { Killiny 2014; Killiny } \\
\text { 2017; Cruz-Munoz et } \\
\text { al. 2019) }\end{array}$ \\
\hline & Eh & $\begin{array}{l}\text { Low Eh: } 50- \\
90 \mathrm{mV} \\
50 \text { to } 150 \mathrm{mV} \\
\text { lower than } \\
\text { apoplast } \\
\text { Strongly } \\
\text { buffered } \\
\text { Micro- } \\
\text { aerophilic }\end{array}$ & $\begin{array}{l}\text { Related to sucrose, amino acid and } \\
\text { accumulation of Salicylic Acid (SA) } \\
\text { Important transport conduit for mobile redox } \\
\text { signals inducing SAR (SA, lipid-derived } \\
\text { molecules, ascorbate, glutathione, ROS, } \\
\text { Systemic Wound Response and Systemic } \\
\text { Acquired Acclimation } \\
\text { Low internal } \mathrm{O}_{2} \text { in the vascular bundle. }\end{array}$ & $\begin{array}{l}\text { Wright and Fisher } \\
\text { 1981; Fromm and } \\
\text { Bauer 1994; Schmidke } \\
\text { et al. 1999; Van } \\
\text { Dongen et al. 2003; } \\
\text { Van Bel and Gaupels } \\
\text { 2004; Hafke et al. } \\
\text { 2005; Rocher et al. } \\
\text { 2006; Gaupels et al. } \\
\text { 2017; Bendix and } \\
\text { Lewis 2018) }\end{array}$ \\
\hline Xylem & $\mathrm{pH}$ & $\begin{array}{l}5.0-6.0 \\
\text { Weakly } \\
\text { buffered }\end{array}$ & $\begin{array}{l}\text { Strongly fluctuates with composition of } \\
\text { dominant ions in the xylem sap, uptake of } \\
\text { inorganic ions (especially nitrogen), external } \\
\text { conditions (microclimatic factors) and stresses }\end{array}$ & $\begin{array}{l}\text { (Gloser et al. 2016; } \\
\text { Pandit and Mukkherjee } \\
\text { 2016) }\end{array}$ \\
\hline
\end{tabular}




\begin{tabular}{|c|c|c|c|c|}
\hline & Eh & $\begin{array}{l}\text { Related to soil } \\
\text { Eh and pH } \\
\text { Weakly } \\
\text { buffered }\end{array}$ & $\begin{array}{l}\text { Has a lower concentration of organic } \\
\text { compounds (sugars, peptides and proteins) } \\
\text { than the phloem. The difference between } \\
\text { xylem pH and soil } \mathrm{pH} \text { creates a difference in } \\
\text { redox potential ( } 50 \text { to } 200 \mathrm{mV} \text { ) between } \\
\text { xylem and soil (corresponding to the Nernst's } \\
\text { equation). For a xylem at pH6 when soil pH is } \\
\text { lower than } 6 \text {, the xylem Eh is lower than soil } \\
\text { the Eh and when soil pH is higher than } 6 \text {, } \\
\text { xylem Eh is higher than soil Eh, with } \\
\text { approximatively }-60 \mathrm{mV} \mathrm{pH}^{-1}\end{array}$ & $\begin{array}{l}\text { (Love et al. 2008; } \\
\text { Pandit and Mukkherjee } \\
\text { 2016) }\end{array}$ \\
\hline \multirow[t]{2}{*}{ Apoplast } & $\mathrm{pH}$ & $\begin{array}{l}4.5-6.0 \\
\text { Buffered } \\
\text { Variable with } \\
\text { tissues } \\
5.2 \text { for rice, } \\
5.75 \text { for barley }\end{array}$ & $\begin{array}{l}\text { Regulated through } \mathrm{H}^{+} \text {-ATPase pumps and } \\
\text { influenced by photosynthesis. } \\
\text { Result of a complex interaction between ion } \\
\text { transport, } \mathrm{H}^{+} \text {-buffering, } \mathrm{H}^{+} \text {-consumption, and } \\
\mathrm{H}^{+} \text {-production. } \mathrm{pH} \text { regulation is energy costly } \\
\text { Low apoplast } \mathrm{pH} \text { in elongating tissues are } \\
\text { associated with growth. Lower apoplastic pH } \\
\text { compared to the cytosolic pH has a crucial } \\
\text { control effect on redox properties of protein } \\
\text { cysteine thiols and overall redox conditions. } \\
\text { Palisade apoplast pH is higher than stomatal } \\
\text { and epidermal apoplast } \mathrm{pH}\end{array}$ & $\begin{array}{l}\text { (Grignon and Sentenac } \\
\text { 1991; Mühling et al. } \\
\text { 1995; Felle 2005; } \\
\text { Geilfus and Mühling } \\
\text { 2011; Landraud et al. } \\
\text { 2013; Visnovitz et al. } \\
\text { 2013; Janku et al. } \\
\text { 2019) }\end{array}$ \\
\hline & Eh & $\begin{array}{l}100-250 \mathrm{mV} \\
50-150 \mathrm{mV} \\
\text { higher than } \\
\text { phloem } \\
\text { Weakly } \\
\text { buffered }\end{array}$ & $\begin{array}{l}\text { Predominantly determined by a high } \\
\text { concentration of ASC; the production of ROS, } \\
\text { an active process in the apoplast that is } \\
\text { controlled by either a plasma membrane- } \\
\text { bound NADPH oxidase or a set of peroxidases } \\
\text { in the cell wall; and large numbers of thiol } \\
\text { groups present on the proteins of the plasma } \\
\text { membrane with a potential capacity } 10 \text { orders } \\
\text { of magnitude lower than the phloem capacity }\end{array}$ & $\begin{array}{l}\text { (Fromm and Bauer } \\
\text { 1994; Felle 2001; } \\
\text { Hafke et al. 2005; } \\
\text { Potters et al. 2010; } \\
\text { Gjetting et al. 2012; } \\
\text { Foyer and Noctor } \\
\text { 2013) }\end{array}$ \\
\hline
\end{tabular}

The low antioxidant efficiency in the apoplast allows ROS to easily accumulate and provides a condition for ROS signaling. Therefore, the apoplastic ROS-antioxidant homeostasis is actively engaged in the reception of, and reaction to, many biotic and abiotic stresses (Podgórska et al. 2017). Similarly, pH signals light intensity changes, drought, lack of oxygen, and the presence of symbiotic partners or microbial attackers (Felle 2001).

The plant apoplast is the first site of direct contact with a pathogen and is thus an interface that mediates the first crosstalk between host and pathogens to perform a crucial role in initiation and coordination of many defense responses (Bolwell et al. 2001; Gupta et al. 2015). Any deviations from the basal cellular redox balance may induce responses that continuously readjust cellular functions; however, diversion of resources to stress responses may limit growth and may thus be detrimental to the plant. The ultimate outcome of these responses must therefore be tightly controlled by the redox signaling networks between organellar and apoplastic signaling systems (Sierla et al. 2013). This is also valid for $\mathrm{pH}$ that acts as a messenger in situations where $\mathrm{pH}$ changes are preconditions for certain processes, e.g., the gravity response, activation of certain transporters in stomatal movements, and possibly for growth in general (Felle 2001).

Intra-cellular variability of Eh-pH

430 Eh-pH conditions in the cell organelles are summarized in Table 5. Cell Eh-pH is strongly buffered to permit

431 marked differences and interplay between organelles. 
mitochondria and chloroplast

\begin{tabular}{|c|c|c|c|c|}
\hline Organelle & pH-Eh & $\begin{array}{l}\text { Homeostasis } \\
\text { level }\end{array}$ & Physiological processes & References \\
\hline \multirow[t]{2}{*}{ Cytoplasm } & $\mathrm{pH}$ & $\begin{array}{l}7.2-7.5 \\
\text { Strongly } \\
\text { buffered }\end{array}$ & $\begin{array}{l}\text { Proton pumps in the plasma membrane and } \\
\text { tonoplast provide intracellular pH } \\
\text { homeostasis and maintenance of a } \\
\text { transmembrane proton gradient. Many } \\
\text { plant functions (nutrient and sugar } \\
\text { transport, cell elongation, organ } \\
\text { development) are highly dependent on the } \\
\text { ability of individual cells to control pH in } \\
\text { the cytosol and in the apoplast. } \\
\text { The cytosolic antioxidant system shields } \\
\text { the nucleus from chloroplast ROS signals. } \\
\text { Photosynthetic ROS signals and redox } \\
\text { imbalances are buffered by cytosolic } \\
\text { antioxidants. Whether they reach the } \\
\text { nucleus depends on the rate of ROS- } \\
\text { formation and strength of the cytosolic } \\
\text { antioxidant system }\end{array}$ & $\begin{array}{l}\text { (Felle 2001; } \\
\text { Hinsinger et al. } \\
\text { 2003; Baier and } \\
\text { Dietz 2005; } \\
\text { Schwarzländer et } \\
\text { al. 2008; Gjetting } \\
\text { et al. 2012) }\end{array}$ \\
\hline & Eh & $\begin{array}{l}-320 \mathrm{mV} \\
\text { to }-312 \mathrm{mV} \\
\text { Strongly } \\
\text { buffered }\end{array}$ & $\begin{array}{l}\text { Organic acid metabolism equilibrates the } \\
\text { redox potential in plant cells but also } \\
\text { transfers redox equivalents between cell } \\
\text { compartments supporting various } \\
\text { metabolic processes }\end{array}$ & $\begin{array}{l}\text { (Schwarzländer et } \\
\text { al. 2008; Jubany- } \\
\text { Mari et al. 2010; } \\
\text { Igamberdiev and } \\
\text { Bykova 2018) }\end{array}$ \\
\hline \multirow[t]{2}{*}{$\begin{array}{l}\text { Mito- } \\
\text { chondria }\end{array}$} & $\mathrm{pH}$ & $\begin{array}{l}\text { 7.8-8 (matrix) } \\
\text { Strongly } \\
\text { buffered }\end{array}$ & $\begin{array}{l}\text { The mitochondrial matrix and chloroplast } \\
\text { stroma need to keep a relatively basic } \\
\text { environment around pH } 8 \text { for optimization } \\
\text { of biochemical reactions occurring in these } \\
\text { two compartments } \\
\text { The generation of a proton gradient across } \\
\text { the inner mitochondrial membrane is an } \\
\text { essential energy conservation event that } \\
\text { couples the oxidation of carbohydrates and } \\
\text { fat to the synthesis of ATP. There is a } \\
\text { close metabolic interaction and redox } \\
\text { exchange between chloroplasts and } \\
\text { mitochondria }\end{array}$ & $\begin{array}{l}\text { (Schwarzländer et } \\
\text { al. 2008; Santo- } \\
\text { Domingo and } \\
\text { Demaurex 2012; } \\
\text { Su and Lai 2017) }\end{array}$ \\
\hline & Eh & $\begin{array}{l}-360 \text { to }-310 \\
\mathrm{mV} \text { in } \\
\text { unstressed } \\
\text { plants } \\
\text { Strongly } \\
\text { buffered }\end{array}$ & $\begin{array}{l}\text { Mitochondria are at the center of redox } \\
\text { dependent processes as they generate ROS } \\
\text { that drive redox-sensitive events and } \\
\text { respond to ROS-mediated changes in the } \\
\text { cellular redox state }\end{array}$ & $\begin{array}{l}\text { (Schwarzländer et } \\
\text { al. 2008; Handy } \\
\text { and Loscalzo } \\
\text { 2012; Müller- } \\
\text { Schüssele et al. } \\
\text { 2020) }\end{array}$ \\
\hline \multirow[b]{2}{*}{ Chloroplast } & $\mathrm{pH}$ & $\begin{array}{l}7 \text { in the dark } \\
\text { to } 7.8-8 \text { in the } \\
\text { light }\end{array}$ & $\begin{array}{l}\text { The chloroplast is buffered at } \mathrm{pH} 8 \text { for } \\
\text { optimization of biochemical reactions }\end{array}$ & (Su and Lai 2017) \\
\hline & Eh & $\begin{array}{l}-400 \text { to }-340 \\
<-300 \text { to }-240 \\
\mathrm{mV} \text { in the } \\
\text { dark } \\
\text { Very } \\
\text { dynamic } \\
\text { signaling } \\
\text { compartment } \\
\text { sensing } \\
\text { perturbations } \\
\text { at the }\end{array}$ & $\begin{array}{l}\text { The chloroplast stroma is highly reducing, } \\
\text { thanks to large amounts of ascorbate, } \\
\text { glutathione and other antioxidants. } \\
\text { Interplay among apoplastic and } \\
\text { chloroplastic redox signaling networks is a } \\
\text { key mechanism in plant stress responses. } \\
\text { Depending on the photo-oxidative strain, } \\
\text { up to almost } 100 \% \text { of the } \\
\text { photosynthetically transported electrons } \\
\text { can be diverted into the antioxidant defense } \\
\text { system that is involved in the synthesis of }\end{array}$ & $\begin{array}{l}\text { (Johnson 2003; } \\
\text { Baier and Dietz } \\
\text { 2005; Noctor et al. } \\
\text { 2007; Sierla et al. } \\
\text { 2013; Dietz et al. } \\
\text { 2016; Foyer and } \\
\text { Noctor 2016; } \\
\text { Serrano et al. } \\
\text { 2016; Lu and Yao } \\
\text { 2018) }\end{array}$ \\
\hline
\end{tabular}


435

436

437

438

439

440

441

442

443

444

445

446

447

448

449

450

451

452

453

454

455

456

457

458

459

460

461

462

463

464

465

466

467

468

469

470

\begin{tabular}{|l|l|l|l|}
\hline & $\begin{array}{l}\text { subcellular } \\
\text { level and to } \\
\text { integrate a } \\
\text { multitude of } \\
\text { intracellular } \\
\text { signals }\end{array}$ & $\begin{array}{l}\text { important mediators of plant defense } \\
\text { responses such as nitric oxide (NO), } \\
\text { salicylic acid (SA), jasmonic acid (JA) and } \\
\text { absicic acid (ABA), as well as secondary } \\
\text { messengers including calcium and ROS. }\end{array}$ & \\
& & & \\
\hline
\end{tabular}

Cellular redox imbalances are usually induced by environmental changes that can be clearly observed in chloroplasts and mitochondria, which are also key players in the regulation of cytosolic and extracellular redox states (Tsang et al. 1991; Dietz 2003). Thus, the photosynthesizing chloroplast functions as a conditional source of important redox and ROS information, which is exploited to tune processes inside the chloroplast, cytosol and nucleus (Dietz et al. 2016). It is interesting that oxidizing conditions in the chloroplast correlate with a high reduction state (Baier and Dietz 2005).

\section{Temporal variability of Eh and $\mathrm{pH}$ in plants}

Photosynthesis is the primary reduction reaction by accumulating electrons and protons. All variations in photosynthetic activity (related to temperature, light, nutrition, etc.) affect the redox state and $\mathrm{pH}$ of the plant. Reduced photosynthesis leads to oxidation and alkalization while efficient photosynthesis in optimal conditions will lead to more acidic and reduced plants (Mühling et al. 1995; Mullineaux and Rausch 2005). Thus, both the ROS and antioxidant levels have diurnal changes. Abrupt variations in temperature and light intensity may lead to ROS accumulation due to disruption of the photosynthetic and respiratory electron transport chains (Kocsy et al. 2013). In rice leaves, $\mathrm{Eh}$ and $\mathrm{pH}$ (and thus, $\mathrm{pe}+\mathrm{pH}$ ) were high at the end of the night (absence of photosynthesis). Both Eh and $\mathrm{pH}$ decreased in the morning, reached a low plateau during the day and increased again at the end of the day (Husson et al. 2018a). This is consistent with: i ) hourly and seasonal variations in photosynthesis as reported by Bernacchi et al. (2006) who reported a raise in instantaneous carbon assimilation in the morning that reached a high plateau during the day but decreased at the end of the afternoon, and ii) the increase of petiole $\mathrm{pH}$ in grapevine during the day, as reported by Masoero and Cugnetto (2018).

Annual, seasonal or irregular fluctuations in environmental conditions also alter the plant's cellular redox state (Kocsy et al. 2013) and antioxidant responses (Ferreira and Domingos 2012). As for Eh, the pH of xylem sap from several species shows seasonal variations, being more acidic in the spring than in the rest of the year (Wilkinson 1999).

Plant age is also an important factor in understanding Eh-pH variation. In the early stage of growth, germination is accompanied by extensive changes in the redox state of seeds. Proteins present in an oxidized form in dry seeds are converted into the reduced state following imbibition of water (Alkhalfioui et al. 2007) so that seed acidification coincides with germination (Footitt and Cohn 1992). With aging, peroxidation of lipid complexes present in seed reserves liberates fatty acids which, at the moment of germination, are transformed by lipolysis into alcohols, aldehydes and ketones (Norton and Harman 1985; Davet 2004). On rice, Husson et al. (2018a) showed that aging of organ (leaf) and at the plant level, was related to acidification and oxidation (increase in Eh) which was consistent with variations in chlorophyll content and net assimilation of $\mathrm{CO}_{2}$ in leaves at different ages (Backhausen and Scheibe 1999). 


\section{Genotypic variability of plant Eh-pH}

In analyzing almost two dozen species, Cornelissen et al. (2011) showed that leaf pH was a species-specific trait with interspecies differences of over $2 \mathrm{pH}$ units. Masoero and Cugnetto (2018) also reported high variability of raw $\mathrm{pH}$ across 49 species. The grapevine, Vitis vinifera, appeared as the most acidic species ( $\mathrm{pH} 3.68$ ) while maize (4.84), potato (5.77), lettuce (5.97), basil (6.08), cauliflower (6.10) and pumpkin (6.38) were less acidic.

Data regarding the differences in redox state-leaf Eh are limited but show differences between:

i) species: Leaf redox potential was $80 \mathrm{mV}$ higher in sunflower than in wheat (Benada 2017). Furthermore, the antioxidant content (both AsA and GSH) was higher in the rhizomes of anoxia tolerant Iris sp. compared with cereal roots that have a higher amount of oxidized DHA. Similarly, rice roots had a lower AsA/DHA ratio (meaning more oxidized conditions) than wheat with values of 0.3 and 0.7 , respectively under aerobic conditions (Blokhina et al. 2000). Deciduous leaves had a higher carbon oxidation (Cox) state than coniferous leaves while goldenrod (Solidago canadensis L.) had a much lower Cox than red clover (Trifolium pretense; Masiello et al. 2008);

ii) varieties: In rice, Nerica 4 (Oryza sativa type japonica $x$ O. glaberrima) variety grown under various conditions (fertilization, growing season) and at different ages had a lower Eh, $\mathrm{pH}$ and $\mathrm{pe}+\mathrm{pH}$ in their last fully developed leaf than those of IRBLTA-2Pi (O. sativa sub. Indica; Husson et al. 2018a).

\section{Environment and plant Eh-pH}

Cellular redox homeostasis is affected by abiotic factors that can affect the ROS level (and their reaction products) at varying levels in the major energy organelles such as chloroplast and mitochondria (Das et al. 2015; Anjum et al. 2016). Oxidative stress may occur under high light intensities over long time periods, during drought, waterlogging, cellular toxicity (under soil contamination or air pollution) or mineral deficiency (Elstner and Osswald 1994). Leaf Eh is altered by external factors such as light, temperature, moisture, nutrition, etc. (Benada 2017). Based on all this, the following section reviews how plant Eh-pH can be affected by abiotic and biotic stresses.

Abiotic stresses and plant Eh-pH

Climatic conditions and plant Eh-pH

500 A non-exhaustive list of reports that highlight how stresses related to low or high light intensity or temperature lead to plant oxidation (increase in $\mathrm{Eh}$ and $\mathrm{pe}+\mathrm{pH}$ ) and alkalization in relation to decreased photosynthesis is summarized in Table 6.

Table 6. Effects of light intensity and temperature on plant Eh-pH

\begin{tabular}{|c|c|c|c|c|}
\hline Stress & & Impact & Mechanisms & References \\
\hline \multirow[t]{2}{*}{$\begin{array}{l}\text { Low or very } \\
\text { high light } \\
\text { intensity }\end{array}$} & Eh & Increased Eh & $\begin{array}{l}\text { Stomatal closure via abscisic acid } \\
\text { pathway; reduced photosynthesis } \\
\text { by reduced } \mathrm{CO}_{2} \text { availability; } \\
\text { reduced photorespiratory carbon } \\
\text { metabolism; photosynthetic } \\
\text { generation of biologically } \\
\text { damaging molecules }\end{array}$ & $\begin{array}{l}\text { (Ort 2001; Benada } \\
\text { 2017; Maai et al. } \\
\text { 2019) }\end{array}$ \\
\hline & $\mathrm{pH}$ & Increased apoplast and & Influence of photosynthesis on & (Raghavendra et al. \\
\hline
\end{tabular}




\begin{tabular}{|c|c|c|c|c|}
\hline & & $\begin{array}{l}\text { xylem } \mathrm{pH} \\
\text { Decreased cytosol } \mathrm{pH} \\
\text { Increased vacuolar } \mathrm{pH}\end{array}$ & $\begin{array}{l}\text { Plasmalemma } \mathrm{H}^{+} \text {-ATPase. } \\
\text { Heat induced electrical signals. } \\
\text { Variable between } \mathrm{C} 3 \text { and } \mathrm{C} 4 \text { plants } \\
\text { and according to } \mathrm{CO}_{2} \text { concentration }\end{array}$ & $\begin{array}{l}\text { 1993; Mühling et } \\
\text { al. 1995; Grams et } \\
\text { al. 2009; Aubrey et } \\
\text { al. 2011) }\end{array}$ \\
\hline \multirow[t]{2}{*}{$\begin{array}{l}\text { Low or high } \\
\text { temperature }\end{array}$} & Eh & $\begin{array}{l}\text { Increased } \mathrm{Eh} \\
(+8 \text { to } 10 \mathrm{mV} \text { in } A \text {. } \\
\text { thaliana cytosol and } \\
\text { nuclei after } 5 \text { days at } \\
\left.42^{\circ} \mathrm{C} \text { vs } 22^{\circ} \mathrm{C}\right)\end{array}$ & $\begin{array}{l}\text { Disruption of cellular homeostasis } \\
\text { and photosynthesis; increase in } \\
\text { photorespiration; overproduction of } \\
\text { ROS; decrease in chlorophyll } \\
\text { content; photoinhibition; } \\
\text { interference with carbohydrate } \\
\text { metabolism; stomatal closure, } \\
\text { inhibition of Rubisco activity }\end{array}$ & $\begin{array}{l}\text { (Allen and Ort } \\
\text { 2001; Noctor et al. } \\
\text { 2007; } \\
\text { Hemantaranjan et } \\
\text { al. 2014; Awasthi et } \\
\text { al. 2015; Benada } \\
\text { 2017; Soengas et al. } \\
\text { 2018; Babbar et al. } \\
\text { 2021) }\end{array}$ \\
\hline & $\mathrm{pH}$ & Increased $\mathrm{pH}$ & $\begin{array}{l}\text { Reduced photosynthesis by extreme } \\
\text { temperatures. } \\
\text { Increase in leaf } \mathrm{pH} \text { with decreasing } \\
\text { temperature } \\
\left(\mathrm{pH}=5.1 \text { at } 35^{\circ} \mathrm{C} \text { increasing to } 6 \text { at }\right. \\
\left.10^{\circ} \mathrm{C}\right)\end{array}$ & $\begin{array}{l}\text { (Masoero and } \\
\text { Cugnetto 2018) }\end{array}$ \\
\hline
\end{tabular}

505

Extreme water conditions usually lead to increased $\mathrm{Eh}$ and $\mathrm{pH}$, except for roots under waterlogged conditions that result in asphyxia (Table 7). Drought and waterlogging also strongly impact plant nutrition through alteration of soil-rhizosphere Eh-pH that determines the form and solubility of major elements and micronutrients (Husson 2013).

Table 7. Effects of drought and waterlogging-submersion on plant Eh-pH

\begin{tabular}{|c|c|c|c|c|}
\hline Stress & & Impact & Mechanisms & References \\
\hline \multirow{3}{*}{ Drought } & Eh & $\begin{array}{l}\text { Strong } \\
\text { oxidation }\end{array}$ & $\begin{array}{l}\text { GSSG/GSH increased } 2.6 \text {-fold in maize } \\
\text { leaves and } 2.3 \text { in roots after } 12 \text { days of } \\
\text { drought. } \\
\text { Decreased photosynthetic rate increased } \\
\text { production of superoxide anion and } \\
\text { hydrogen peroxide by twofold } \\
\text { In Arabidopsis thaliana, cytosolic Eh was } \\
\text { significantly raised from }-312 \mathrm{mV} \text { to }-302 \\
\text { mV after } 11 \text { days of water stress, although } \\
\text { cytosolic Eh is strongly buffered }\end{array}$ & $\begin{array}{l}\text { (Jubany-Mari et } \\
\text { al. 2010; Li et al. } \\
\text { 2014; Ahmad et } \\
\text { al. 2016) }\end{array}$ \\
\hline & $\mathrm{pH}$ & $\begin{array}{l}\text { Usually, } \\
\text { increase in } \\
\text { plant pH. } \\
\text { Variable } \\
\text { with plant } \\
\text { species }\end{array}$ & $\begin{array}{l}\text { Leaf and root } \mathrm{pH} \text { increase in some drying } \\
\text { plants by unknown processes; however, } \\
\text { a leaf } \mathrm{pH} \text { decrease is reported for } \\
\text { grapevine, Arabidopsis thaliana, Pisum } \\
\text { sativum and Trifolium repens and poplar. } \\
\text { There is a nonlinear relationship between } \\
\text { leaf xylem sap pH and soil water content } \\
\text { in Brassica napus and Raphanus sativus, } \\
\text { but no change in Helianthus annuus }\end{array}$ & $\begin{array}{l}\text { (Wilkinson and } \\
\text { Davies 1997; } \\
\text { Bahrun et al. } \\
\text { 2002; Gloser et } \\
\text { al. 2016; Secchi } \\
\text { and Zwieniecki } \\
\text { 2016; Masoero } \\
\text { and Cugnetto } \\
\text { 2018) }\end{array}$ \\
\hline & $\begin{array}{l}\text { Electrical } \\
\text { Conductivity } \\
\text { (EC) }\end{array}$ & $\begin{array}{l}\text { Increase in } \\
\text { xylem EC }\end{array}$ & $\begin{array}{l}\text { Accumulation of sugars in the xylem } \\
\text { apoplast observed under water stress } \\
\text { conditions is controlled by xylem pH and } \\
\text { lower xylem pH is related to loss of xylem } \\
\text { transport function to eventually result in } \\
\text { accumulation of sugars, thus raising xylem } \\
\text { EC }\end{array}$ & $\begin{array}{l}\text { (Secchi and } \\
\text { Zwieniecki 2016) }\end{array}$ \\
\hline $\begin{array}{l}\text { Waterlogging } \\
\text { Submersion }\end{array}$ & Root Eh & $\begin{array}{l}\text { Strong } \\
\text { reduction } \\
\text { Asphyxia }\end{array}$ & $\begin{array}{l}\text { Reduced oxygen }\left(\mathrm{O}_{2}\right) \text { availability in plant } \\
\text { roots creates a barrier for gas diffusion } \\
\text { into plant cells, inhibiting free gas }\end{array}$ & $\begin{array}{l}\text { (Thomson and } \\
\text { Greenway 1991; } \\
\text { Blokhina et al. }\end{array}$ \\
\hline
\end{tabular}




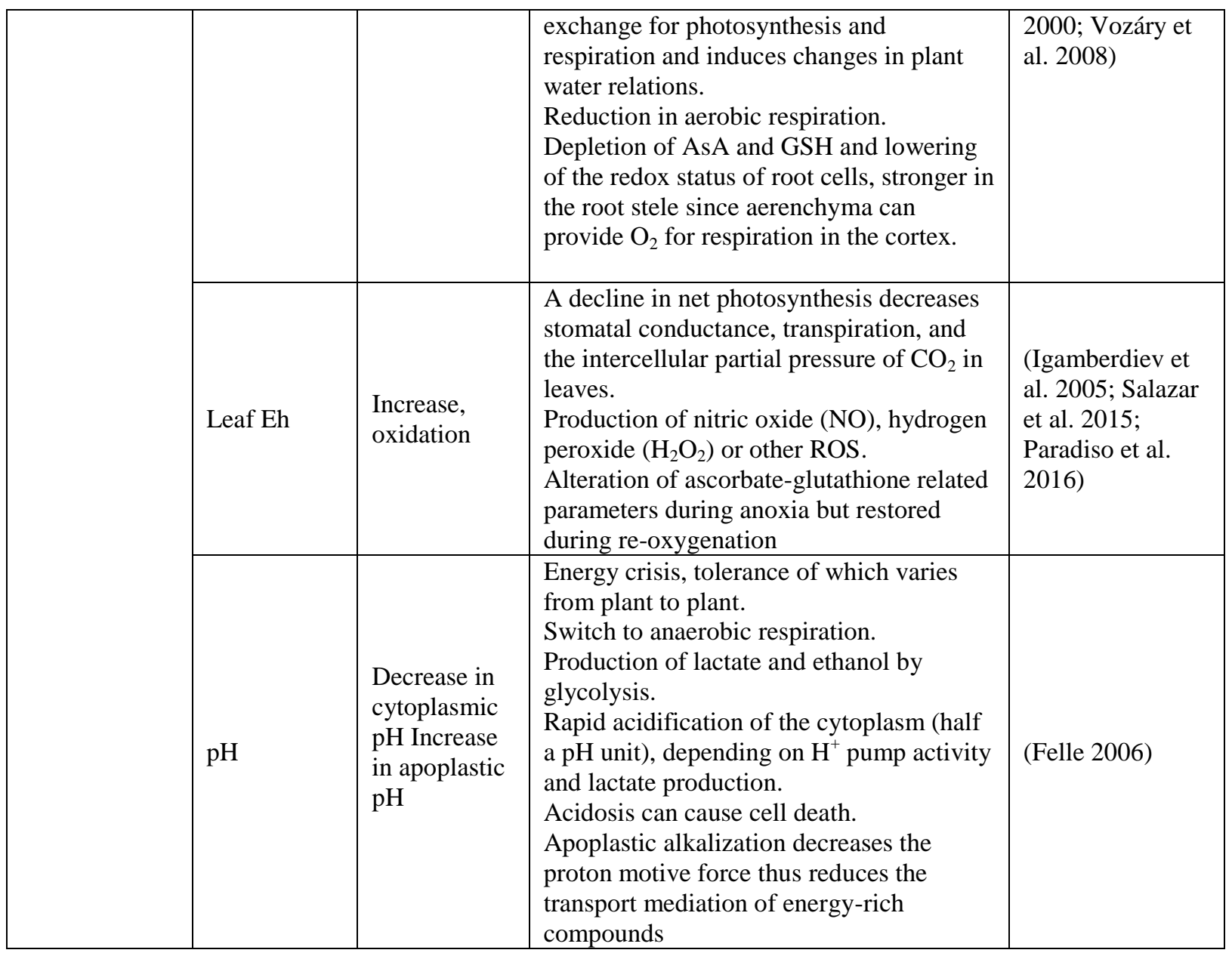

513 Edaphic conditions and plant Eh-pH

514 Overall, leaf $\mathrm{pH}$ proved to be species-specific but remarkably constant for a given species grown on soils at $\mathrm{pH}$ 515 ranging from 3.67 to 6.51 (Cornelissen et al. 2011). Both high and low soil-rhizospheric pH led to oxidation of 516 wheat leaves (Bhuyan et al. 2019). pH regulation mobilizes numerous $\mathrm{H}^{+}$-pumps all of which employ the same 517 universal physical principles of converting redox energy into proton pumping (Thomma et al. 2011). Thus,

518 leaves of wheat seedlings grown under extremely acidic or strongly alkaline-stress showed strong oxidative 519 damage compared with the control at $\mathrm{pH}$ 7.0. A sharp increase in $\mathrm{H}_{2} \mathrm{O}_{2}$ content (134 and 90\%) and in 520 malondialdehyde - a stress indicator produced from lipid peroxidation (199\% and 194\%) - were observed at both 521 an extremely acidic ( $\mathrm{pH} 4.0)$ and strongly alkaline $\mathrm{pH}$ ( $\mathrm{pH}$ 8.5), respectively (Bhuyan et al. 2019). Leaves of rice 522 grown under aerobic conditions (high soil Eh, low soil pH, no water stress) had a higher Eh (20mV higher) and 523 lower $\mathrm{pH}$ ( -0.2 to $-0.4 \mathrm{pH}$ units) compared with those of plants grown under anaerobic conditions (low soil Eh 524 and high soil pH; Husson et al. 2018a). High soil pH leads to higher xylem Eh than soil Eh while low pH leads to lower xylem Eh than soil Eh. At constant soil Eh, high soil pH leads to xylem oxidation (Love et al. 2008).

527 Salt stress is a major plant stress that also leads to oxidation and alkalization. There is a rapid increase in $\mathrm{H}_{2} \mathrm{O}_{2}$ 528 and superoxide radical in Indian mustard (Brassica juncea) under severe salt stress conditions where an 529 oxidative burst occurred within $30 \mathrm{mn}$ and increased membrane damage up to 2.8, 7.8 and 9.0 fold, within 30 530 minutes, 2 and 24 hours after stress induction, respectively (Ranjit et al. 2016). The decline in maize leaf growth 531 under salt stress was due to an inhibition of $\mathrm{H}^{+}$-pumping activity and increase in apoplastic $\mathrm{pH}$ of leaves (Pitann 

where it spread systemically throughout the entire apoplast, starting from the leaf base towards the tip. The alkalization then increased ABA in the leaf apoplast and guard cells (Geilfus 2017). Apoplast pH affected functionality by reducing the stomatal pore size in Vicia faba during the onset of $\mathrm{Cl}^{-}$salinity via effects on ABA. Based on this mode of action, it was hypothesized that, under conditions of soil salinity, $\mathrm{Cl}^{-}$-inducible alkalization of the leaf apoplast reduces the transpiration rate and, thus, reduces the uptake of $\mathrm{Na}+$ and $\mathrm{Cl}^{-}$from the soil solution (Geilfus 2017).

Aluminum (Al) is a major plant growth-limiting factor in acid soils (Melakerberhan et al. 1995). The primary site of $\mathrm{Al}$ accumulation and toxicity is the root meristem. Al triggers lipid peroxidation and ROS production in roots, inhibits respiration and depletes ATP (Yamamoto et al. 2003). In barley, alleviation of aluminum toxicity by hydrogen sulfide was related to elevated ATPase and suppressed oxidative stress (Dawood et al. 2012). Several other toxic elements are known to lead to plant oxidation, including cadmium (leading to formation of callose in phloem cells), zinc, mercury, and antimony (Cuypers et al. 2001; Benitez-Alfonso et al. 2011; Sobrino-plata et al. 2014; Ortega et al. 2017).

547 In general, high levels of metal ions such as $\mathrm{Co}, \mathrm{Cu}, \mathrm{Fe}, \mathrm{Mn}, \mathrm{Mo}, \mathrm{Ni}$, and $\mathrm{Zn}$, and trace levels of toxic metals $(\mathrm{Pb}$,

$548 \mathrm{Cd}, \mathrm{Hg}, \mathrm{As}, \mathrm{Cr}, \mathrm{Ag}, \mathrm{Al}, \mathrm{Cs}, \mathrm{Sr}, \mathrm{U})$ have been reported to negatively affect plant growth, metabolism, development, and overall productivity, due mainly to accelerated ROS formation and, to a lower extent, through other reactions (Anjum et al. 2014). High soil pe+pH also increases $\mathrm{Cd}$ availability from increased bacterial activity (Wang et al. 2020). Finally, GSH is a key antioxidant for the plant to cope with mercury and cadmium stress (Sobrino-plata et al. 2014). Likewise, the ascorbic acid (AsA) redox system efficiently protects the plant and plays a key role in metal-metalloid stress tolerance (Chen et al. 2017b). A deficiency of GSH and AsA leads to susceptibility to toxic elements such as Cadmium (Jozefczak et al. 2015).

\section{5}

\section{Mineral nutrition and plant Eh-pH}

557 Mineral nutrition impacts plant photosynthesis and, as a consequence, plant Eh-pH. Any kind of N, P or K 558 deficiency leads to plant oxidation. While $\mathrm{N}$ deficiency results in alkalization, $\mathrm{P}$ or $\mathrm{K}$ deficiency results in 559 acidification (Table 8). The concentration of amino acids and sugars in the apoplast of leaf and stem tissue may 560 increase with Ca, B, Zn or K deficiency (Huber et al. 2011), which leads to an increase in EC. Furthermore, Si 561 content decreases with excess applications of $\mathrm{N}$, which can also affect disease tolerance (Gupta et al. 2017). 562 Besides the availability of $\mathrm{N}$, the form in which it is absorbed by the plant influences soil Eh-pH and has a 563 dramatic impact on plant physiology (Marschner et al. 1986).

Table 8. Impact of mineral nutrition $(N, P, K)$ on plant Eh-pH

\begin{tabular}{|l|l|l|l|l|}
\hline Element & Variable & Effect of deficiency & Physiological processes & References \\
\hline \multirow{2}{*}{$\mathrm{N}$} & $\mathrm{pH}$ & $\begin{array}{l}\text { Increases root and } \\
\text { shoot xylem pH by } \\
0.2-0.3 \text { units }\end{array}$ & $\begin{array}{l}\text { N deprivation decreases whole plant } \\
\text { transpiration which can potentially close } \\
\text { stomata }\end{array}$ & $\begin{array}{l}\text { (Dodd et al. 2003; } \\
\text { Huber and } \\
\text { Thompson 2007) }\end{array}$ \\
\cline { 2 - 5 } & $\mathrm{Eh}$ & $\begin{array}{l}\text { Oxidation and altered } \\
\text { antioxidant responses }\end{array}$ & $\begin{array}{l}\text { Deprivation leads to changes in phenolic } \\
\text { metabolism and oxidative status } \\
\text { Varying patterns of superoxide dismutase } \\
\text { isoforms. }\end{array}$ & $\begin{array}{l}\text { (Huber and } \\
\text { Thompson 2007; } \\
\text { Kováčik and } \\
\text { Bačkor 2007) }\end{array}$ \\
\hline $\mathrm{P}$ & $\mathrm{pH}$ & Acidification & Promotion of root elongation by & (Anuradha and \\
\hline
\end{tabular}




\begin{tabular}{|c|c|c|c|c|}
\hline & & & acidification; $\mathrm{pH}$ control of anthocyanins & $\begin{array}{l}\text { Narayanan 1991; } \\
\text { Chen et al. 2013) }\end{array}$ \\
\hline & Eh & $\begin{array}{l}\text { Oxidation and altered } \\
\text { antioxidant responses }\end{array}$ & $\begin{array}{l}\text { Alterations in photosynthetic physiology, } \\
\text { including reductions in } \mathrm{CO}_{2} \text { assimilation } \\
\text { rates, down-regulation of photosynthesis- } \\
\text { related genes and photoinhibition at the } \\
\text { photo-system II level. Photo-oxidative } \\
\text { stress is characterized by an increased } \\
\text { production of ROS in chloroplasts }\end{array}$ & $\begin{array}{l}\text { (Kováčik and } \\
\text { Bačkor 2007) } \\
\text { (Hernández and } \\
\text { Munné-Bosch } \\
\text { 2015) }\end{array}$ \\
\hline \multirow[b]{2}{*}{ K } & $\mathrm{pH}$ & Acidification & $\begin{array}{l}\mathrm{K} \text { is an alkalizing element, and high } \mathrm{K} \\
\text { nutrition leads to higher plant } \mathrm{pH}\end{array}$ & (Ward 1960) \\
\hline & Eh & $\begin{array}{l}\text { Oxidation and altered } \\
\text { antioxidant responses }\end{array}$ & $\begin{array}{l}\text { K enhances antioxidant defense in plants } \\
\text { and protects them from oxidative stress } \\
\text { Accumulation of soluble sugars in K- } \\
\text { deficient plants in both leaves and roots }\end{array}$ & $\begin{array}{l}\text { (Kováčik and } \\
\text { Bačkor 2007; } \\
\text { Amtmann et al. } \\
\text { 2008; } \\
\text { Hasanuzzaman et } \\
\text { al. 2018) }\end{array}$ \\
\hline
\end{tabular}

567 The form of nitrogen absorbed by the plant and the solubility of essential elements are related not only to the

568 type of fertilizer applied but also to soil Eh-pH conditions. The main form of $\mathrm{N}$ absorbed is mainly determined

569 by pe+pH with a balance between both forms being reached close to pe+pH=14 (Husson 2013). Drought limits

570 biological activity and thus leads to a raise in soil Eh and pe+pH, with a strong negative impact on Fe and $\mathrm{Mn}$

571 solubility, and increased nitrification. For example, a four-fold reduction in nitrate reductase activity was

572 observed following 6 days of severe drought ( $\mathrm{Li}$ et al. 2014). In contrast, submersion causes a strong and rapid

573 decrease in soil $\mathrm{Eh}$, with a slight raise in $\mathrm{pH}$, leading to low pe+pH, thus to reduced, soluble Fe and $\mathrm{Mn}$, and to

574 ammonification (Ponnamperuma 1972; Cottes 2019). Thus, the dominant form of mineral nitrogen in soil is

575 nitrate in dry-oxidized-alkaline soils and ammonium in waterlogged-reduced-acidic soils.

577 Nitrate absorption strongly alkalizes plant roots and shoot (apoplast) while ammonium absorption leads to strong

578 acidification, with a strong impact on other nutrients solubility-absorption. Absorption of nitrate is an active 579 process that increases root respiration to reduce Eh in the rhizosphere while leading to shoot oxidation (Table 9).

Table 9. Impact of $\mathrm{N}$-form of nutrition $\left(\mathrm{NH}_{4}^{+} \mathrm{vs} \mathrm{NO}_{3}{ }^{-}\right)$on plant Eh-pH

\begin{tabular}{|c|c|c|c|c|c|}
\hline Form & $\begin{array}{l}\text { Va } \\
\text { ria } \\
\text { ble }\end{array}$ & Impact on plant & Processes & $\begin{array}{l}\text { Impact on } \\
\text { other } \\
\text { nutrient } \\
\text { availability }\end{array}$ & References \\
\hline \multirow[t]{2}{*}{$\mathrm{NO}_{3}^{-}$} & $\mathrm{pH}$ & $\begin{array}{l}\text { Strong alkalization } \\
\text { of the roots- } \\
\text { rhizosphere (up to } \\
+2 \mathrm{pH} \text { units) } \\
\text { Alkalization of } \\
\text { shoots, leaf apoplast }\end{array}$ & $\begin{array}{l}\text { Release by roots of } \mathrm{OH}^{-} \text {to } \\
\text { compensate for the negative charge } \\
\text { absorbed with } \mathrm{NO}_{3}^{-} \\
\text {Strongly basic hydroxides resulting } \\
\text { from assimilation of } \mathrm{NO}_{3}^{-} \text {in the } \\
\text { leaf }\end{array}$ & \multirow[t]{2}{*}{$\begin{array}{l}\text { Decrease in } \\
\text { Fe, Mn, Bo, } \\
\mathrm{Cu}, \mathrm{Zn}, \mathrm{Ca} \\
\text { and } \\
\text { solubility } \\
\text { absorption }\end{array}$} & \multirow{2}{*}{$\begin{array}{l}\text { (Marschner et } \\
\text { al. 1986; } \\
\text { Marschner } \\
\text { 1995; Foyer } \\
\text { and Noctor } \\
\text { 2013; Elmer } \\
\text { and Datnoff } \\
\text { 2014; Singh } \\
\text { and Schulze } \\
\text { 2015; Geilfus } \\
\text { 2017; Sun et } \\
\text { al. 2020) }\end{array}$} \\
\hline & Eh & $\begin{array}{l}\text { Roots-rhizosphere } \\
\text { reduction }\end{array}$ & $\begin{array}{l}\text { Activation of pumps for active } \mathrm{N} \\
\text { absorption increases root } \\
\text { respiration (oxygen consumption). } \\
\text { Reduction of } \mathrm{NO}_{3}{ }^{-} \text {to } \mathrm{NH}_{4}^{+} \text {requires } \\
8 \text { electrons, and } 8 \text { to } 16 \mathrm{ATP} \text {. Nitrate } \\
\text { as } \mathrm{N} \text {-source generates higher } \\
\text { energetic cost ( } 5 \text { to } 12 \%) \text { for } \\
\text { assimilation, reduction to amino } \\
\text { acid and pH control, as compared to }\end{array}$ & & \\
\hline
\end{tabular}




\begin{tabular}{|c|c|c|c|c|c|}
\hline & & & $\begin{array}{l}\text { ammonium nutrition. } \\
\mathrm{NO}_{3}{ }^{-} \text {increases photorespiration }\end{array}$ & & \\
\hline \multirow[t]{2}{*}{$\mathrm{NH}_{4}^{+}$} & $\mathrm{pH}$ & $\begin{array}{l}\text { Strong acidification } \\
\text { of the roots- } \\
\text { rhizosphere (up to -2 } \\
\text { pH units) } \\
\text { Acidification of } \\
\text { shoots, leaf apoplast }\end{array}$ & $\begin{array}{l}\text { Release by roots of } \mathrm{H}^{+} \text {to } \\
\text { compensate for the positive charge } \\
\text { absorbed with } \mathrm{NH}_{4}^{+}\end{array}$ & \multirow{2}{*}{$\begin{array}{l}\text { Decreases in } \\
\mathrm{P}, \mathrm{K}, \mathrm{S}, \mathrm{Ca} \text {, } \\
\mathrm{Mg} \text { and } \mathrm{Mo} \\
\text { solubility- } \\
\text { absorption } \\
\mathrm{NH}_{4}^{+} \\
\text {absorption is } \\
\text { antagonist to } \\
\text { cations as } \\
\mathrm{Ca}^{2+}, \mathrm{Mg}^{2+} \text { or } \\
\mathrm{Mn}^{2+}\end{array}$} & \multirow{2}{*}{$\begin{array}{l}\text { (Marschner et } \\
\text { al. 1986; } \\
\text { Marschner } \\
\text { 1995; Zou and } \\
\text { Zhang 2003; } \\
\text { Li et al. 2013; } \\
\text { Elmer and } \\
\text { Datnoff 2014; } \\
\text { Singh and } \\
\text { Schulze 2015) }\end{array}$} \\
\hline & $\mathrm{Eh}$ & $\begin{array}{l}\text { Reduction of the } \\
\text { shoots } \\
\begin{array}{l}\text { Oxidation of the } \\
\text { roots }\end{array}\end{array}$ & $\begin{array}{l}\text { Absorption of strongly reduced } \\
\mathrm{NH}_{4}^{+} \text {, reduced energetic cost for } \\
\text { protein formation } \\
\text { Activation of ATP- } \mathrm{H}^{+} \text {pumps for } \\
\text { pH regulation, consuming electrons }\end{array}$ & & \\
\hline
\end{tabular}

Biotic stresses and plant Eh-pH

As with abiotic stresses, biotic stresses usually lead to apoplast alkalization and oxidation. Infection by viruses, response to microbial pathogen attack is a ubiquitous early part of the resistance mechanisms of plant cells. ROS, especially hydrogen peroxide $\left(\mathrm{H}_{2} \mathrm{O}_{2}\right)$, seem to play a dual role in plant defense by eliciting localized deathlimitation of host plant cells and pathogens and by acting as a diffusible signal for the induction of antioxidant and pathogenesis-related genes in adjacent plant tissues (Hernández et al. 2016). A second component of the resistance mechanism is extracellular alkalization, occurring as a result of the $\mathrm{Ca}^{2+}$ and proton influxes, and the $\mathrm{K}^{+}$efflux common to most elicitation systems as one of the earliest virus responses (Bolwell et al. 2002). In an advanced stage of viral infection, photosynthetic rates of diseased plants only attain 75 to $80 \%$ of those of

593 the healthy plants, on a leaf area basis. This reduced photosynthesis can be related to loss of chloroplast 594 (chlorosis, as in viral and bacterial infection), loss of leaf area (destruction as in the case of necrotrophic fungi or 595 bacteria), occlusion of the vascular system, or stomata closure (Goodman et al. 1967; Hernández et al. 2016).

596 Plants infected by fungi, bacteria or viruses also display a common response, namely an increase in respiration, one of the most general physiological phenomena of diseased plants (Goodman et al. 1967).

598 Similarly, an oxidative response also occurs following an attack by herbivores as H. zea (Bi and Felton 1995). A 599 general disturbance of redox balance is induced in tissues also by aphid feeding, including the accumulation of oxidases and phenolic substrates and loss of reducing activity and protein (Jiang and Miles 1993). Overall, following insect attacks, ROS accumulate in apoplastic as well as in symplastic regions. Apoplastic burst of ROS acts as a first barrier against subsequent attack by pathogens and herbivores (War et al. 2012). A systemic suppression of photosynthesis is often associated with caterpillar herbivory where oxidative modifications are

604 observed (Thivierge et al. 2010), e.g. oxidation of ascorbic acid (Goggin et al. 2010). Aphids also oxidize plant phenolic monomers that act as their deterrent, into inert polymers (Jiang 1996). Finally, wounded plants secrete sap with a characteristic acidic $\mathrm{pH}$ of 5.0 to 5.8 and high content of different phenolic compounds such as lignin and flavonoid precursors. Plants typically respond to wounding, including that caused by sucking insects, by mobilizing and oxidizing phenolic compounds (Miles and Oertli 1993; Hwang et al. 2017). 
We consider Eh-pH homeostasis as a unifying process that attempts to shed light on the multiple processes related to plant-pest interactions. A model of these interactions is proposed based on the assumption that plants become susceptible to pests when imbalanced Eh-pH conditions in their compartments match the specific Eh-pH ranges at which the various pests can thrive, usually in oxidized plants (high $p e+\mathrm{pH}$ ). Once attacked, a major defense reaction of plants is a localized oxidation of the pathogen or wounds.

617 Hence, this "redox" model (Fig. 2) correlates: i) the Eh-pH conditions of the plants in their various compartments (roots, shoots, stems, grains, fruits and apoplast, xylem, phloem, cell, and organelles) which are the result of genotype, age, management practices and the various stresses related to the abiotic and biotic environments, their intensity and their duration; ii) the specific conditions at which specific pests can thrive depending on the pest type, their reproductive cycle, metabolism and living style (soil-borne vs air-borne,

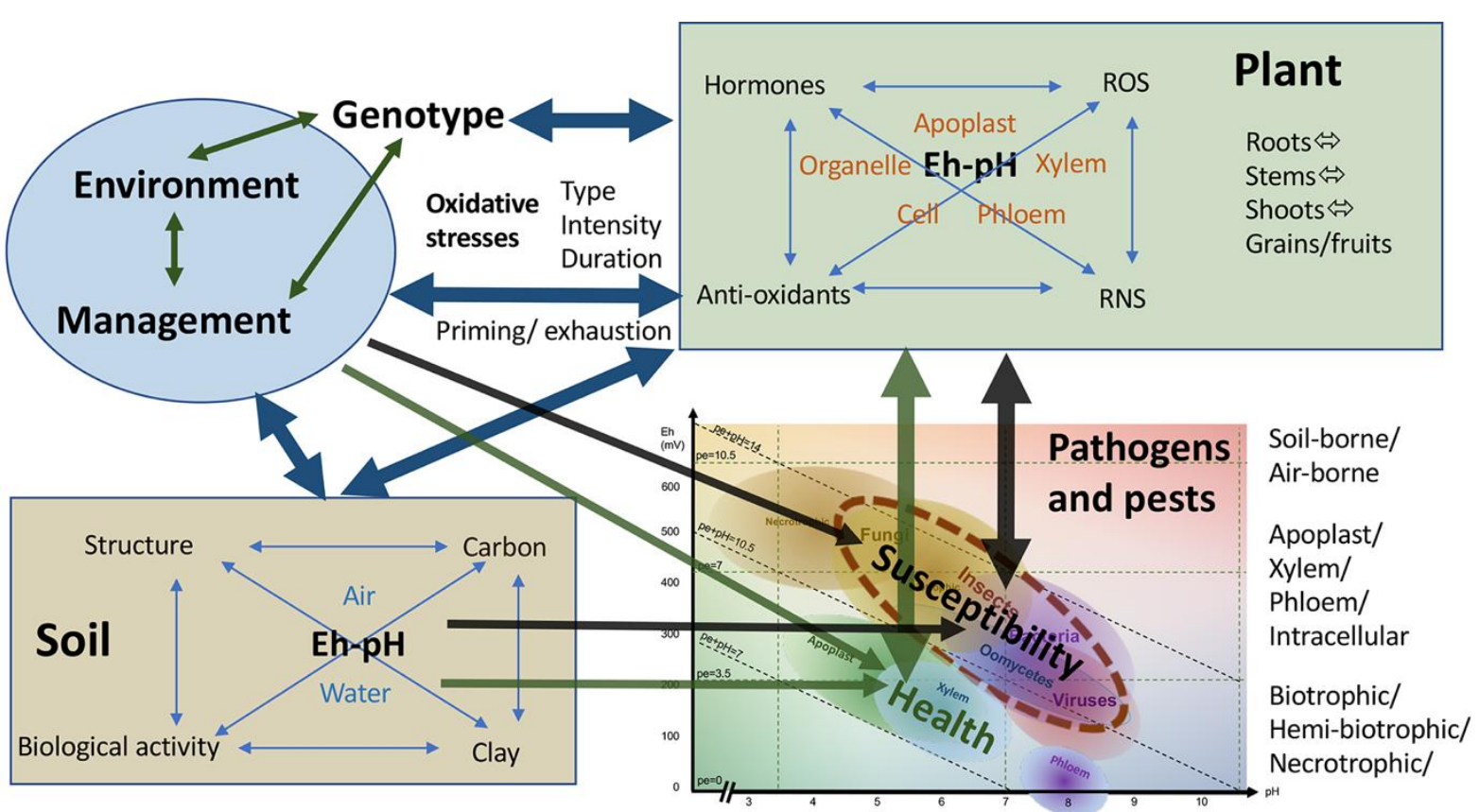

Fig. 2: Model of GxExMxP interactions in a "Redox" perspective. Environment and management practices impact soil Eh-pH (water and air in interaction with soil structure, carbon, biological activity and clay). Environment (management practices) and soil Eh-pH induce oxidative stresses in plants, which together with genotype affect plant Eh-pH in the various plant compartments through interactions between ROS, RNS, hormones and antioxidants. These antioxidants can be primed or inversely exhausted in relation to type, duration and intensity of the various stresses. In this model, plants become susceptible when imbalanced Eh-pH conditions in plant compartments match the specific Eh-pH conditions at which the various pests can thrive.

634 The effects of the multiple and complex abiotic and biotic factors and their interactions can be integrated into 635 these simple parameters to provide a powerful tool for analyzing GxExMxP interactions in a temporal and spatialized perspective. 

resistance to various pests? time is summarized in Fig. 3.

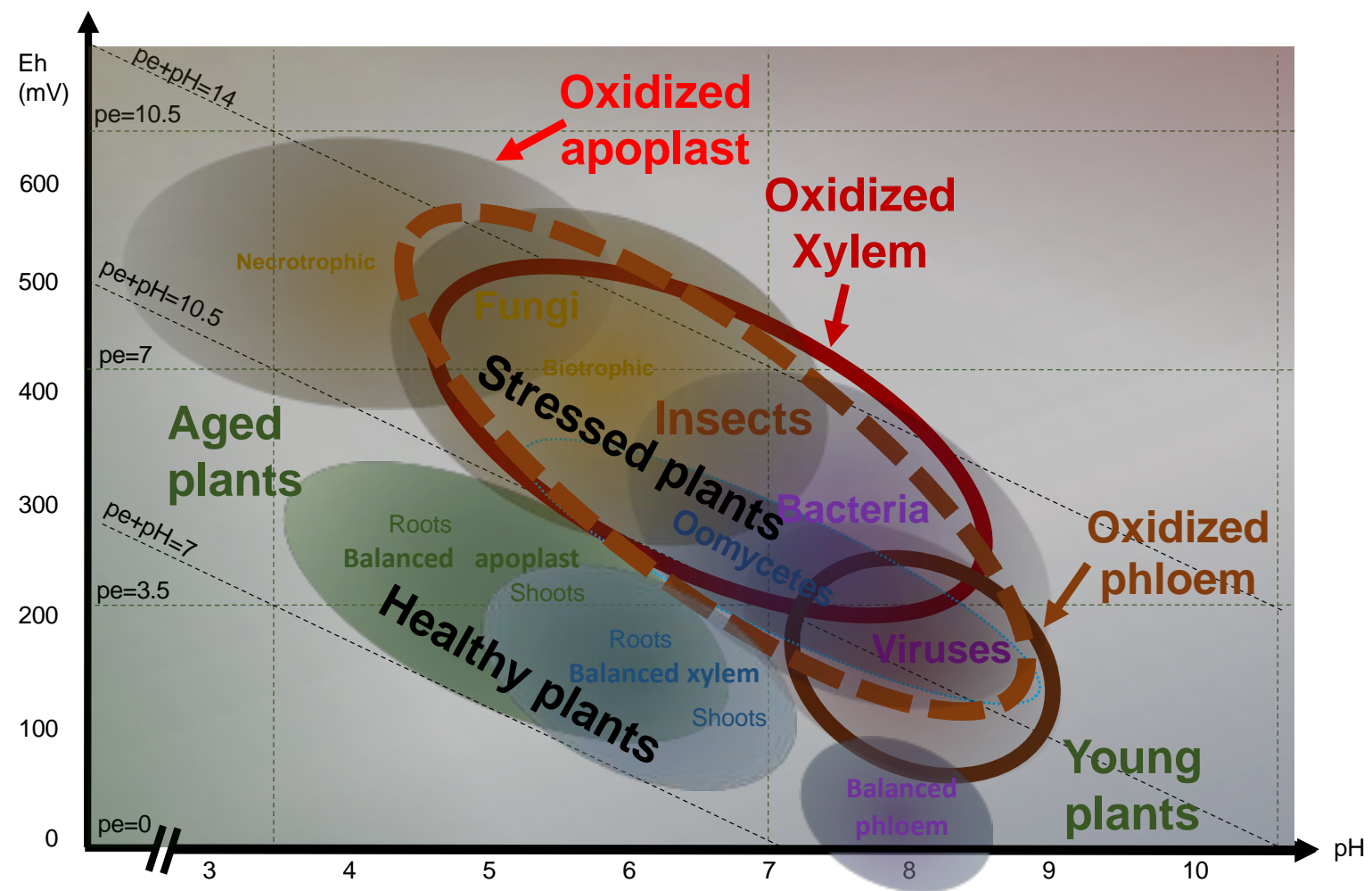

Fig. 3. Eh-pH map of indicative zones where the main groups of pests can thrive, corresponding to oxidized plants. Adapted from section 2 (Tables 1 and 2) and section 3. Viruses develop in alkaline phloem and possibly xylem, as do most bacteria. Inversely, most fungi prefer the acidic and more oxidized apoplast. Oomycetes often thrive in moderately oxidized apoplast, usually at higher $\mathrm{pH}$ than their fungal counterparts. Insects have different preferences, according to their feeding mode: xylem or phloem sucking insect at higher $\mathrm{pH}$ and lower Eh compared with biting-chewing insects; larvae at lower pe+pH and higher $p H$ compared with adults. These are only tendencies for the main groups of pathogens and pests, as optimal Eh-pH conditions are specific. Although some pathogens are ubiquistic, able to develop in a large range of Eh-pH conditions, most pathogens can develop only in a specific, narrow Eh-pH range (Rabotnova and Schwartz 1962). plant organs as illustrated by four examples: i) the initial development of fungi (fungal wilt pathogens) in the apoplast (more acidic and oxidized than the vascular system), and where many soil-borne fungi are necrotrophic (developing in the more acidic-oxidized conditions of the roots) while most of the biotrophic pathogens, such as rusts and powdery mildews, occur on the above-ground portions of the plants that are less acidic and oxidized than the roots (Raaijmakers et al. 2009); ii) the preferential development of many Gram-positive bacteria, 
including phytoplasma and proteobacteria, in the alkaline phloem and in the xylem, which rapidly become alkaline upon various stresses (Bové and Garnier 2003; Padan et al. 2005), iii) the invasion of plants by obligate intracellulars, e.g. viruses, through the alkaline and reduced phloem (Hipper et al. 2013); and iv) the feeding habits of insect vectors of these pathogens, which are xylem (bacteria) or phloem (viruses and bacteria), such as sucking insects (Garnier et al. 2001; Wielkopolan and Obre 2016).

Similarly, the spatial distribution of pests, between organs, is correlated to Eh-pH niches. Examples are: i) the resistance to wheat stripe rust (Puccinia striiformis $f$. sp. tritici,) within same-aged plants was lower on the uppermost leaf than in the second leaf, while it was even higher in the third leaf [These leaves are not the same 'age'] (Farber and Mundt 2017), in accordance with higher Eh levels in the young and not fully developed leaves; ii) the highest infection by Rice Yellow Mottle Virus in the flag leaf (oxidized, alkaline; Joseph et al. 2011), iii) the higher resistance of rice to bacterial blast (Xanthomonas campestris pv. oryzae), in old, mature leaves compared with young leaves (with low Eh and high pH (Koch and Mew 1991); and iv) the highest resistance to thrips (Frankliniella occidentalis) of the youngest fully opened Capsicum leaves compared to older leaves (van Haperen et al. 2019).

Temporal variations in plant Eh-pH are also correlated to timing of susceptibility-tolerance-resistance, and Eh$\mathrm{pH}$ alteration with age could be involved in the processes implied in ontogenic resistance at plant or organ level. Some aged plants naturally develop acidic and less reduced conditions, which could explain the acquired immunity of plants against bacterial diseases (thriving in alkaline and moderately reduced conditions) with aging. This has been described with Xanthomonas campestris in rice (Koch and Mew 1991) and in Arabidopsis thaliana (Hess et al. 2005), which requires intercellular accumulation of SA. Interestingly, in tomato, age-related resistance to Phytophthora infestans has been related to ethylene (ET) and SA (Shah et al. 2015). Plant-leaf aging is related to acidification that matches with the higher susceptibility of young rice plant-leaves to viruses (thriving in alkaline conditions), as exemplified for Rice Yellow Mottle Virus (Joseph et al. 2011). Likewise, young grapevine leaves present a high Grapevine Fanleaf Virus level during the whole vegetative period while mature leaves, tendrils and flower-berry clusters do so only at the beginning of the vegetative period (Krebelj et al. 2015). In contrast, the decreasing susceptibility of grapevine leaves to Erysiphe graminis while aging (Calonnec et al. 2018) could be related to lower Eh in the fully developed leaves (Husson et al. 2018a). This is also true for the increasing susceptibility of aging rice plants to Helminthosporium oryzae and Magnaporthe oryzae (formerly Pyricularia oryzae; Padmanabhan and Ganguly 1954). Temporal variability in plant Eh-pH may also explain that Capsicum plants start to develop resistance to thrips (Frankliniella occidentalis) once they are between 4- to 8-weeks-old (van Haperen et al. 2019). Likewise, cabbage plants aging from 3 to 9 weeks increased pre-imaginal mortality of the moth, Plutella xylostella, (Lepidoptera) and reduced its larval development rate, pupal weight and fecundity (Campos et al. 2003). Finally, an Eh-pH perspective on modulation of plant immunity by light, circadian rhythm and temperature could also be valuable by providing insights into the important role of circadian rhythm in the plant defense system against pests (Hua 2013; Lu et al. 2017).

701 Can genotypic differences in plant Eh-pH explain susceptibility, tolerance or resistance to pests? 
As for spatio-temporal variations, genotypic variability in plant Eh-pH is correlated to and may explain differential susceptibility to the various types of pests. Under this Eh-pH perspective, it can be hypothesized that any pathosystem is related to specific plant Eh-pH values. Masoero and Cugnetto (2018) reported a predisposition towards fungal infection when the $\mathrm{pH}$ was more acidic, with grapevine $(\mathrm{pH} 3.69)$ and apple $(\mathrm{pH}$ 5.04) as model plant species. They also reported a tendency towards bacterial infection when the $\mathrm{pH}$ was less acidic, as exemplified for pear ( $\mathrm{pH}$ 5.52). The high propensity of tomato to bacterial and viral diseases (Blancard 2012) might also be related to its high $\mathrm{pH}$ (5.46), in addition to a strong increase in xylem $\mathrm{pH}$ under extreme water conditions (i. e. up to 7.0 and 8.0 under flooding and drought, respectively; Wilkinson 1999; Jackson et al. 2003). The differences in Eh-pH values among plant species might also explain why aerial hemibiotrophic and biotrophic fungi are specialized to a limited number of hosts, with similar Eh-pH conditions. For instance, the hemibiotrophic M. oryzae is limited to rice, a few other cereals including wheat (Debona et al. 2012), or wild grasses such as Leersia hexandra, Echinochloa crusgalli, or Brachiaria mutica (Jashvantlal 2008). This pathogen does not develop, for instance, on cruciferous species such as rapeseed (Brassica napus) that has different Eh-pH conditions. In contrast, the causal agents of phoma stem canker of rapeseed (Leptosphaeria maculans and L. biglobosa), major biotrophic fungi, are limited to brassicas and do not develop on cereals (Rouxel and Balesdent 2005). Furthermore, the low Eh in rice might explain why this plant is not infected by Sclerotinia sclerotiorum, a, necrotrophic and damaging plant pathogen that can infect 383 species in 225 taxonomic genera and 64 plant families (Purdy 1979).

720 A second hypothesis can also be proposed that, besides the specific recognition processes depending on host and 721 plant pathogen genotypes, varietal resistance, tolerance and susceptibility to pests is related to differences in 722 basal Eh-pH and genetic capacity of the variety to sustain a balanced Eh-pH. For instance, the rice variety Nerica

7234 sustains a low $\mathrm{Eh}$ and $\mathrm{pH}$ and is resistant to several strains of the rice blast pathogen while the more oxidized 724 rice variety IRBLTA-2Pi was highly susceptible to some strains of the pathogen (Fukuta et al. 2019). Similarly, 725 greater varietal resistance of wheat to the blast pathogen was related to a more efficient antioxidative system in 726 the removal of excess ROS generated during the infection process of M. oryzae, limiting cellular damage caused 727 by the fungus (Debona et al. 2012).

728 However, it should be clearly stated that these are only major trends observed, which should not be generalized 729 without caution. They are based on "mean" plant Eh-pH conditions, diffferences between varieties can be as 730 important as differences between species, and local conditions in the different plant compartments also have to 731 be considered, and related to specific pathogens or pests and their requirements.

733 Can Eh-pH imbalance related to abiotic stresses explain plant susceptibility, tolerance and resistance 734 to pests?

735 A common feature in the response to all stresses is the onset of oxidative stress through the production of ROS 736 (Carvalho et al. 2015; Sewelam et al. 2016). One of the earliest responses of plants to pathogens, wounding, 737 drought, extremes of temperature or physical and chemical shocks is the accumulation of ROS such as 738 superoxide, hydroxyl radicals, hydrogen peroxide, singlet oxygen, etc. The oxidative stress that often ensues 739 with and following infection is a widespread phenomenon. It is extensively observed in plants exposed to most, 740 if not all, biotic and abiotic stresses (Shao et al. 2008). Plants synthesize a large pool of antioxidants such as 741 ascorbate, tocopherol, and proteinaceous thiols (thioredoxin, peroxiredoxin and glutaredoxin) that interact with 
ROS to maintain redox homeostasis (Kapoor et al. 2015). Thus, during stress, the requirements for energy increases with the intensity of respiration from exergonic processes, and plant's entropy also increases (Dragičević 2015). As a consequence, most abiotic stresses generally result in oxidation with an exception being in roots during waterlogging-flooding. Similarly, abiotic stresses, most often, lead to apoplast alkalization. This systemic $\mathrm{pH}$ increase may be a secondary effect without functional implications that results from ion movements or proton-pump regulation. There is increasing evidence that apoplast alkalization is part of a mechanism to withstand stress (Geilfus 2017).

A schematic summary highlighting the impacts of major abiotic stresses on plant Eh-pH homeostasis is presented in Figure 4 with zones indicating where the main pest groups can thrive optimally. It is important to recognize that waterlogging, drought (Fig. 4a) and salinity (Fig. 4b) stresses are most directly encountered by roots although the effects may be manifest throughout the plant (Bostock et al. 2014). This is also the case when soil imbalances occur ( $\mathrm{pH}$, Eh, mineral deficiency, toxic elements etc.). In contrast, light, temperature (Fig. 4a) and air pollution are most directly encountered by aerial parts. This Fig. 4 illustrates how plants could become susceptible to various diseases following abiotic stresses in relationship to oxidation, or inversely, why waterlogging reduces diseases caused by fungi such as Fusarium poae (Martínez et al. 2019).

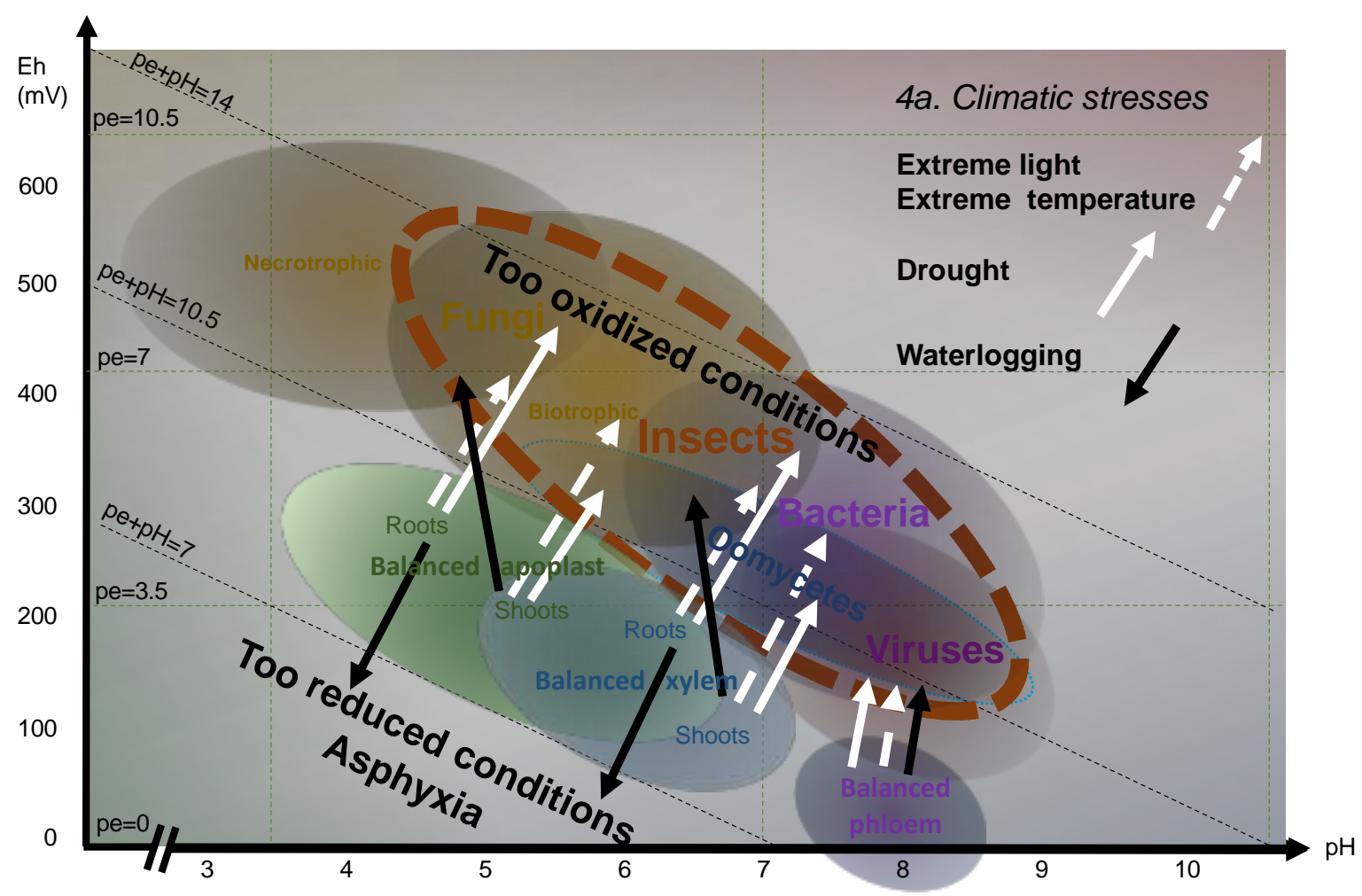




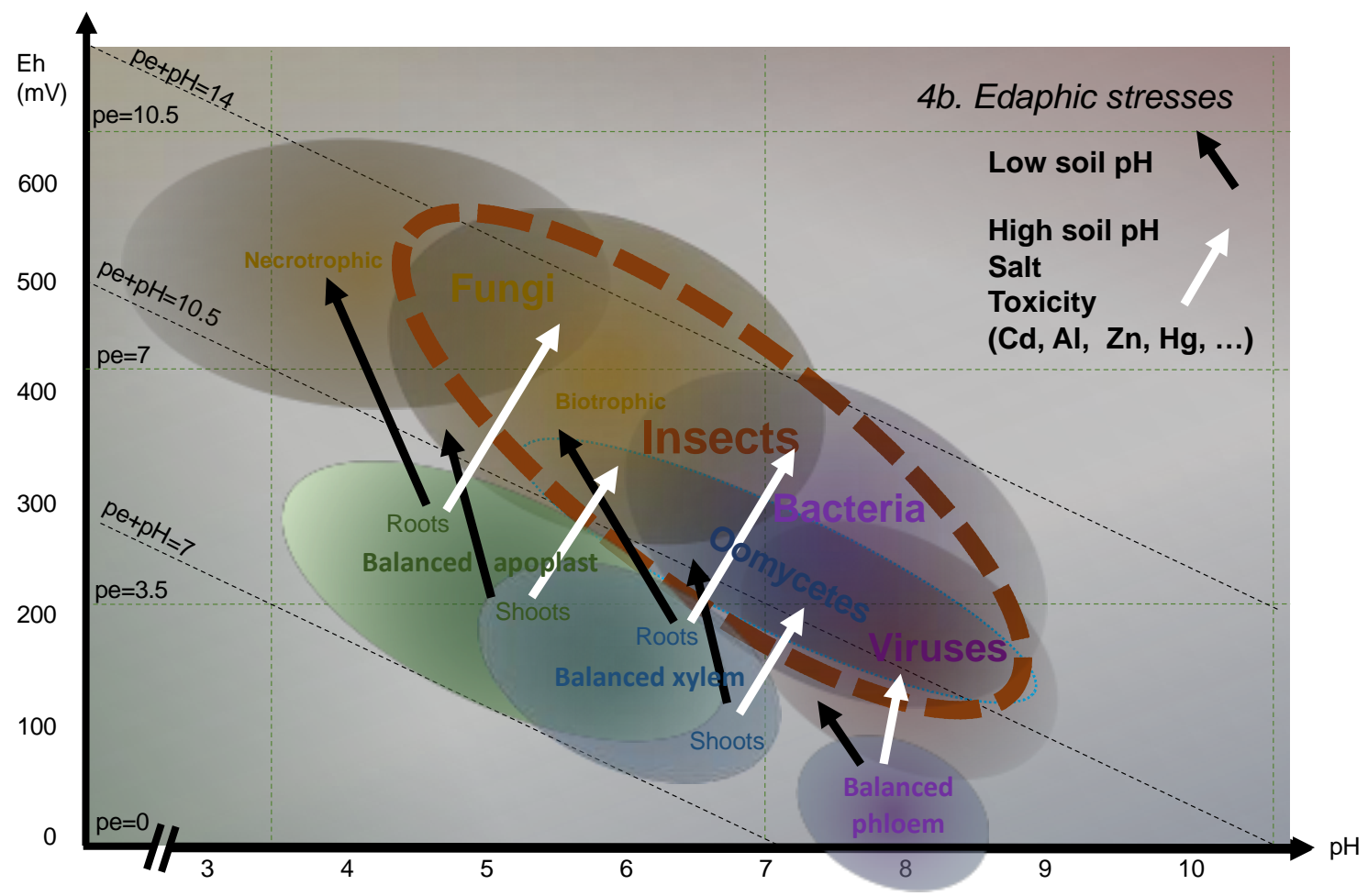

762 Fig. 4: Impact of abiotic stresses leading to unbalanced redox conditions in plant parts ( $p H$-Eh map) in relation 763 zones indicating optima where the main pest groups can thrive (adapted from Tables 1 and 2). 4a. Climatic stresses. 4b. Edaphic stresses. Edaphic stresses often lead to plant oxidation and increased plant susceptibility except for waterlogging that results in root asphyxia and, shoot oxidation or acidification. Low soil pH leads to further acidification in the rhizosphere, while high soil pH results in further alkalization of the rhizosphere.

Variations of plant Eh-pH following stress has been correlated with increased susceptibility to various types of pests (Schoeneweiss 1975). Abiotic stresses can predispose plants to potentially aggressive hemi-biotrophic pathogens to result in severe disease despite very low levels of inoculum. Perhaps the most pronounced impact of abiotic stress is to facilitate diseases caused by opportunistic or facultative pathogens and those present in association with their hosts such as epiphytes or endophytes (Lamichhane 2015). An example is the root- and crown-infecting pathogens Pythium ultimum and Fusarium spp.; air-borne pathogens, such as Alternaria spp. and Botrytis cinerea; and many canker-causing pathogens of woody perennials (Bostock et al. 2014). For instance, summer heat is conducive to epidemics of cytospora canker of Alnus (Worrall et al. 2010).

In contrast, abiotic stresses can also result in reduced incidence or severity of diseases caused by obligate or biotrophic, pathogens. Exceptions are diseases caused by some viruses, fungi, and nematodes (Bostock et al. 2014). Thus, pathogen infection on already drought-stressed plants can either result in plant resistance to pathogens, through drought-induced activation of basal defense mechanisms or, inversely, can result in susceptibility due to a weakened basal defense (Bertrand 1976).

782 To understand how abiotic stresses, including the edaphic ones, can either increase or decrease plant 783 susceptibility to various pests, a dynamic approach is required and additional parameters must be considered, namely: i) the intensity and duration of the stress since abiotic stresses occurring prior to infection affect susceptibility of plants in different ways; ii) the synergistic occurrence of multiple stresses and their combined 
effects (Lamichhane 2015); and iii) availability of anti-oxidant pools in the plant, their ability to counterbalance the oxidative stresses and their possible exhaustion.

\section{Predisposition, acclimation, priming effect, exhaustion and death in a "redox" perspective} Stress may affect plant diseases through a range of effects on the pathogen, host, or the host-pathogen interaction. The concept of predisposition implies an effect on the host rather than on the pathogen (Sorauer 1974). Stresses or nutrition that cause stomatal closure or formation of a thicker cuticle may prevent invasion by pathogens. In some cases, however, pathogens may enter a plant regardless of stress and affect disease development more than infection (Schoeneweiss 1975). Drought-induced pathogen resistance is presumably due to enhanced induction of antimicrobial and PR-proteins activated by drought. These compounds can protect plants during early stages of pathogen infection. Plant susceptibility to drought may be attributed to high levels of $\mathrm{ABA}$ in drought stressed plants since this hormone interferes with pathogen-induced plant defense signaling and thereby reduces the expression of defense-related genes (Ramegowda and Senthil-Kumar 2015).

Bostock et al. (2014) developed a model of plant response to integrate the general adaptation syndrome with the concept of disease severity, disease duration and disease predisposition. In this model, there is an alarm stage following an abiotic stress event which corresponds to the maximum predisposition before the acclimationresistance stage (maximum resistance) to conclude with a final collapse, exhaustion and death stage. In an Eh-pH perspective (Fig. 5a), this could be seen as a first phase for the increase in ROS (and ABA) that is followed by the production of antioxidants and phytoalexins by the plants (acclimation stage, maximum resistance). The collapse stage could be regarded as the exhaustion of the antioxidant capacity of the plant that leads to a further increase in oxidation level. The collapse, exhaustion and death phase could, therefore, be split into two sub-phases: i) a high susceptibility phase that could still be reversible, especially to viruses and necrotrophic pathogens, that is related to strongly oxidized conditions upon exhaustion of antioxidants, and ii) a death phase related to irreversible oxidation. Furthermore, the high production of antioxidants following ROS activation after a moderate stress could have a priming effect to induce a greater capacity to respond to further stimulus, lowering the plant redox state, and, thus, preparing it for a rapid response in case of pest attacks. One hypothesis could be that plants that sustain a lower Eh level can more readily produce reduced primary and secondary metabolites such as phenolics, SA and phytoalexins or redox regulated molecules such as plant pathogenesis-related proteins (Fobert and Després 2005; Balmer et al. 2015). Indeed, compounds that induce priming are reported to promote stronger and faster responses to stress by modulating the oxidative environment and interacting with signaling pathways mediated by SA, JA and ET (González-Bosch 2018).

820 Under natural conditions, biotic and abiotic stresses frequently co-occur. As a consequence, common molecular

821 signaling pathways governing adaptive responses to individual stresses can interact (Nguyen et al. 2016). A 822 mechanism to study multiple-stress interactions (Bateman, 1978) recognizes that plant responses to a 823 combination of stresses such as heat and drought may differ from those to individual stresses. Abiotic stress applications are likely to influence plant-pathogen interactions and vice versa (Prasch and Sonnewald 2015). For instance, when applied in combination, drought and herbivory had an additive effect on specific processes 
826 involved in secondary metabolism and defense responses, including protease inhibitor activity (Nguyen et al. 827 2016). Abiotic and biotic stress interactions can occur at multiple levels, depending on the type of stress 828 (osmotic, ionic), growth characteristics, infection strategy of the pest (biotroph-necrotroph, mode of infection by 829 direct penetration or through plant openings such as stomata, etc.) or infection stage of the host (Kissoudis et al. 830 2014).

832 Molecular and biochemical studies indicate that there are extensive overlaps in abiotic and biotic stress 833 responses and there is some evidence for a universal stress response transcriptome for which a model involving

834 the recruitment of ROS and phytohormones to sequentially engage defense responses has been proposed; 835 however, it is unclear how the sequence is disrupted by predisposing stress events (Bostock et al. 2014). Plants 836 use common pathways and components in the stress-response relationship. This phenomenon, which is known as 837 cross-tolerance, allows plants to adapt or acclimate to a range of different stresses following exposure to one. 838 Redox signals appear to have a central role in these common pathways (Pastori and Foyer 2002).

840 In their seminal review on enhancing crop resilience to combined abiotic and biotic stress, Kissoudis et al. 841 (2014) showed that stress factors affect the homeostasis of chemical signals in the apoplasm such as Ca ${ }^{2+}, \mathrm{ROS}$

842 and pH levels. A combination of abiotic stress with pathogen infection potentially derails hormone and systemic 843 ROS homeostasis. Under multiple stresses, the intensity of one stress affects the plant's responses to further 844 stresses. For instance, plants exposed to mild drought stress activate the basal defense response that enables them 845 to defend against pathogen infection. In contrast, severe drought causes leakage of cellular nutrients into the 846 apoplast that facilitates successful pathogen infection (Ramegowda and Senthil-Kumar 2015).

847 Considering both the oxidative stress and the regulation of antioxidant systems, Lushchak (2014) proposed four 848 levels of an intensity-based classification of oxidative stress, namely: i) a basal oxidative level; ii) a low intensity 849 oxidative stress, in which markers of ROS-induced and ROS-sensitive functions can be measured; iii) an 850 intermediate intensity oxidative stress, and iv) a high intensity oxidative stress where markers of oxidatively 851 modified components dominate.

852 In the proposed hypothesis in this paper we integrate the various models and classifications through an Eh-pH 853 perspective. Consideration of oxidative stresses in combination with plant responses (antioxidant systems in 854 interaction with hormones) results in a dynamic and spatialized plant Eh-pH model (Fig. 5). In this model, low to 855 moderate stress after an alarm stage (predisposition upon oxidation), leads to the production of antioxidants (in 856 relation to $\mathrm{ABA}$ ) and priming of plant defense mechanisms and decreased plant susceptibility in an acclimation 857 stage in which SA, JA-ET induce SAR-ISR. 
Figure 5a.

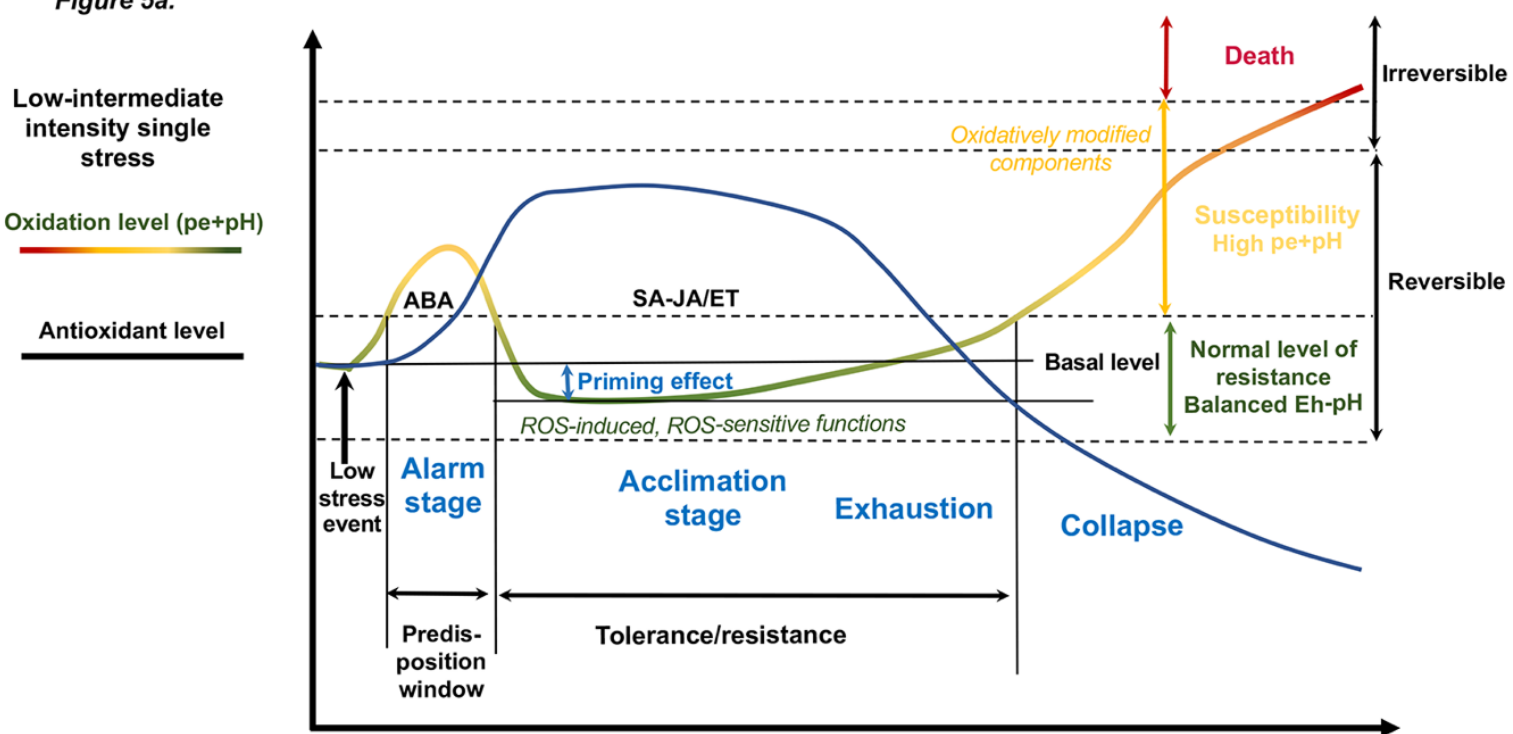

Stress duration

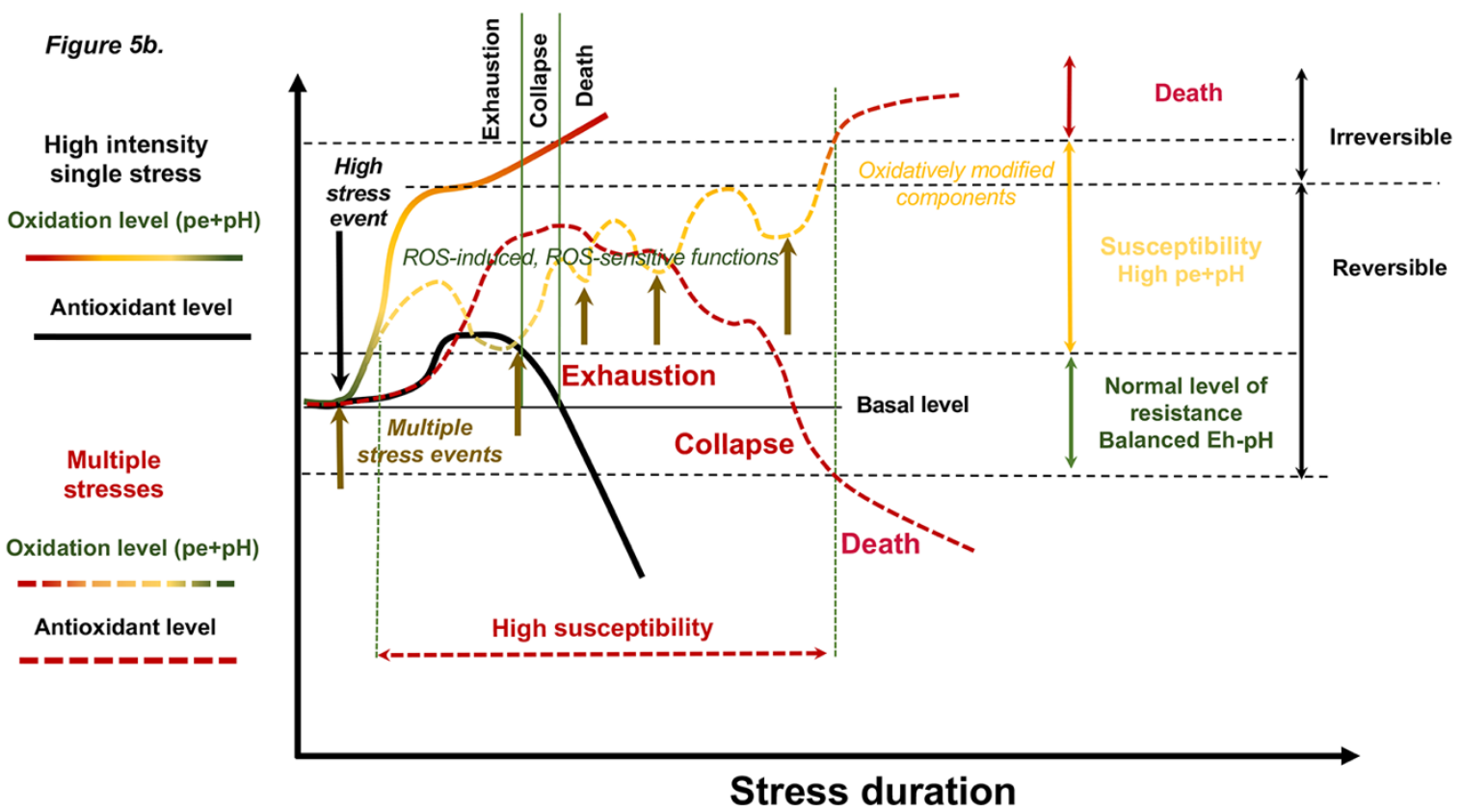

Fig. 5. Model of plant responses to abiotic and biotic stresses and disease predisposition by combining models

861 from Bostock et al. (2014) and Lushchak (2014) in an Eh-pH perspective. 5a. Low to intermediate stress intensity of long duration. 5b. High stress intensity and multiple stresses. Production of antioxidants after a moderate stress induces an acclimation stage, but exhaustion of the antioxidant pool. Upon high intensity, multiple stresses or long stress duration leads to plant cell collapse and death. The stronger the abiotic stress or the higher the number of simultaneous stresses, the faster the exhaustion (the shorter the tolerance-resistance phase). The longer the stress or more consecutive stresses, the higher the risk of exhaustion of antioxidants. As long as ROS-induced and ROS sensitive functions can be sustained, oxidation-susceptibility can be reversed. Upon exhaustion of antioxidant pools, strong oxidation leads to irreversible collapse and death. 
High intensity stress or multiple combined stresses lead to a rapid increase in oxidative stress and a rapid exhaustion of plant antioxidant pools and results in increased susceptibility to pests, without possibility of acclimation (Fig. 5b). Several observations suggest that there is a critical glutathione status below which the accumulation of pathogen-defense related molecules is inhibited and, consequently, disease resistance is impaired (Noctor et al. 2011). Similarly, consecutive multiple stresses, or prolonged single stress lead to progressive exhaustion of antioxidant capacity and increased plant oxidation to ultimately result in irreversible collapse and death. Photosynthesis, the primary mechanism for reduction, is also fundamental in restoring the antioxidant pools by regenerating NADPH (Reduced Nicotinamide Adenine Dinucleotide Phosphate; mid-point potential: Em $\mathrm{NADP}+\mathrm{NADPH}=-320 \mathrm{mV}$ ) which then results in regeneration of GSH (Em GSSG/GSH: $-230 \mathrm{mV}$ ) and ASC (Em DHA/ASC: $+90 \mathrm{mV}$; Noctor 2006). Paradoxically, chloroplasts produce various forms of ROS, and photosynthesis also produces $\mathrm{H}_{2} \mathrm{O}_{2}$ in the peroxisomes because of photorespiration (Exposito-Rodriguez et al. 2017). These ROS play an important role in signaling, but they also need to be scavenged to sustain redox homeostasis. Removal of $\mathrm{H}_{2} \mathrm{O}_{2}$ in chloroplasts occurs through ASC-dependent and TRX-dependent pathways (Foyer and Shigeoka 2011). One of the effects of oxidative stress is to decrease chlorophyll biosynthesis (Aarti et al. 2006) so that oxidative stresses generally decrease photosynthesis. Following exhaustion of antioxidant pools, redox imbalance negatively alters photosynthesis and thus alters the plant's capacity to regenerate antioxidant pools.

888

This model of Eh-pH homeostasis, as a central component of plant health, proposes a coherent perspective by deciphering the multiple interactions between abiotic stress and plant susceptibility, tolerance and resistance to pests. The model introduces a framework explaining how abiotic stresses can alter plant-pest interactions by enhancing host plant susceptibility or, inversely, by priming tolerance to pests in relation to antioxidant pools in the plant. This model may also be useful to decipher the poorly understood interactions among multiple biotic stresses acting simultaneously or, to the contrary, to understand how some pests may alter plant response to abiotic stresses (Pandey et al. 2017).

896

897 Can Eh-pH imbalance related to biotic stress explain biotic-biotic interactions and cohorts of pests?

898 Studies of plant-pathogen interactions have historically focused on simple models of infection involving single 899 pathosystems. In contrast, in the wild, microbes are part of complex multispecies consortia-communities 900 (Lamichhane and Venturi 2015). Plant infections often involve multiple species or genotypes and exhibit complexities that are not captured in individual pathosystems (Abdullah et al. 2017). Simultaneous infection of

902 a single plant by various pathogens has been recognized as an important modulator of host resistance and a 903 driver of pathogen evolution (Tollenaere et al. 2017). Even commensal bacteria can enhance virulence of 904 opportunistic pathogens via cross-metabolism. For example, Streptococcus gordonii enhances the bioavailability 905 of oxygen during infection to allow Aggregatibacter actinomycetemcomitans to shift from a primarily 906 fermentative to a respiratory metabolism that promotes its growth and persistence (Stacy et al. 2016). 907 Mechanistically, respiratory metabolism enhances the fitness of A. actinomycetemcomitans in vivo by increasing 908 ATP yields via central metabolism and creating a proton motive force (Stacy et al. 2016). Furthermore, host 
plant nutrition can significantly influence the growth and condition of phytophagous insects that influence their susceptibility to pathogens (Shikano et al. 2010).

The recognition of Eh-pH niches specific to each pest could help decipher the three main types of interactions in co-infection systems (Seabloom et al. 2015; Abdullah et al. 2017): i) competition, in which competing pathogens develop physical barriers or utilize toxins to exclude competitors as reported for Fusarium verticilloides and Ustilago maydis in maize (Jonkers et al. 2012). This may involve interactions between pests that have different Eh-pH optimum conditions with each one altering these conditions to enhance its fitness for its own benefit at the expense of the others; ii) cooperation, whereby pathogens beneficially interact, by providing mutual biochemical signals essential for pathogenesis. This could be regarded as pathogens having similar Eh-pH optimum conditions. Similar Eh-pH niches could potentially explain the many fungi-fungi, virus-virus and bacteria-bacteria synergistic interactions as reviewed by Lamichhane and Venturi (2015) or mixed infections for example as reported for Rice Yellow Mottle Virus and Xanthomonas oryzae in rice (Tollenaere et al. 2017); and iii) coexistence, whereby pathogens can stably coexist through niche specialization.

Similarly, the Eh-pH perspective proposes a framework to explain how a pathogen can render a host: i) more vulnerable to other pathogen attacks, as is the case of Pseudomonas syringae predisposing plants to invasion by the necrotrophic ascomycetes Alternaria brassicicola or Albugo candida that allow subsequent infections by several opportunistic pathogens (Abdullah et al. 2017). This induced susceptibility by development of the first pathogen might be attributed to a further imbalance of Eh-pH in the various plant compartments (apoplast, xylem, phloem, intracellular); ii) more resistant through the induction of a systemic defense-signaling cascade that restores Eh-pH conditions unfavorable to pathogens that confers resistance to subsequent attacks, as exemplified by Pseudomonas fluorescens (Ongena et al. 2005).

The Eh-pH homeostasis hypothesis could also help explain how above-ground infestation of whitefly (Bemisia tabaci) in peppers (Capscicum annuиm) can induce below-ground resistance against the gram-negative Ralstonia solanacearum that develops in an aerobic, alkaline condition through SA-dependent signaling, that leads to an increase of root-associated gram+ bacteria (Yang et al. 2011). This perspective may also explain how a host plant's nutritional status can significantly influence the growth and condition of phytophagous insects and, consequently, the susceptibility of the latter to pathogens (Shikano et al. 2010). Finally, this hypothesis might help clarify the 'crosstalks' among hormones involved in plant defense and help improve the model of SAmediated defense against biotrophs and JA-ET-mediated defense against necrotrophs. The latter model is currently regarded as being too simplistic since defense responses are thought to be fine-tuned not only to particular plant-pathogen combinations (Abdullah et al. 2017), but also to multiple biotic and abiotic stresses and co-infections.

Revisiting mineral nutrition and plant-pest interactions with an Eh-pH perspective

946 Interactions between mineral nutrition and plant pests include how nutrient supply alters pest prevalence and 947 influences competitive interactions among coinfecting pathogens (Lacroix et al. 2014). However, several reviews (Datnoff et al. 2007; Huber and Haneklaus 2007; Amtmann et al. 2008; Dordas 2008; Spann and 

inconsistent and, in some cases, contradictory results because (i) no information was available whether the supply of these nutrients was low, optimal or excessive relative to plant needs; (ii) the form of $\mathrm{N}$ or other nutrients supplied (e.g., ammonium or nitrate which are metabolized differently) were not provided; and iii) lack of consideration for differences in infection patterns between obligate and facultative parasites (Huber et al. 2011). Other sources of inconsistency can be related to interactions between elements (co-application, antagonism, synergy), the time of application (Amtmann et al. 2008; Elmer and Datnoff 2014), the crop developmental stage at the time of nutrient application (Dordas 2008); soil type and general growing conditions, especially $\mathrm{pH}$, and other possible plant stresses (water, temperature, biotic stress, etc.). Furthermore, the mode of entry of the pathogens, and the plant tissue involved first (leaf or root, apoplast, xylem or phloem) and the plant physiological stage at which they develop. Although the effect of these situations may be well known, they frequently are not considered in the published studies. Many of these studies attributed the form of $\mathrm{N}$ to $\mathrm{pH}$ conditions even though Eh conditions are as important as $\mathrm{pH}$ relative to $\mathrm{N}$ forms. For example, the $\mathrm{NH}_{4}{ }^{+}$form is dominant at low pe+pH $(<14)$ while $\mathrm{NO}_{3}{ }^{-}$dominates at higher pe+pH (Husson, 2013).

An Eh-pH perspective in relation to plant nutrition and entry point of pathogens that defines various types of pests and characterizes spatio-temporal variations in a plant's susceptibility or resistance to them and feeding modes of pests, could shed light on these interacting processes and identify consistencies that are currently lacking. This section illustrates the importance of a spatialized and dynamic Eh-pH perspective by providing a few examples.

$N$ nutrition and plant-pest interactions in an Eh-pH perspective

971 Nitrogen availability for plants is one of the most important factors influencing disease development (Elmer and

972 Datnoff 2014; Gupta et al. 2017); however, the mechanisms by which $\mathrm{N}$ affects disease development remains 973 elusive and sometimes appears inconsistent (Gupta et al. 2017). Nitrogen-deficient plants may not provide the nutrient environment necessary for obligate pathogens, whereas nitrogen excess may inhibit the production of

975 defense responses to other pathogens (Elmer and Datnoff 2014). Nitrogen is an essential component of amino acids, enzymes, hormones, phenolics, phytoalexins, and proteins. Interestingly, all of these molecules have direct effects on disease development (Elmer and Datnoff 2014; Gupta et al. 2017), and are involved in redox homeostasis.

980 Most of the conflicting reports regarding the role of nitrogen in plant disease may be due to a failure in 981 recognizing and reporting the form of nitrogen used in the experiments (Elmer and Datnoff 2014). In their review of nitrogen and plant diseases, Huber and Thompson (2007) highlighted that application of nitrogen

983 under unspecified form resulted in an increased and decreased disease level in 20 and 22 cases, respectively. 984 Similarly, $\mathrm{NH}_{4}{ }^{+} \mathrm{N}$ application resulted in an increased and decreased disease level in 8 and 16 cases, 985 respectively. Likewise, $\mathrm{NO}_{3}{ }^{-} \mathrm{N}$ application led to an increased and decreased disease level in 11 and 9 cases, 986 respectively. Earlier, Huber and Watson (1974), reported an increase and decrease in diseases level due to $\mathrm{NH}_{4}{ }^{+}$ 987 nutrition in 24 and 20 cases, respectively while they reported an increase and decrease in diseases due to $\mathrm{NO}_{3}{ }^{-}$in 98820 and 24 cases, respectively. 

provides an interesting perspective that helps disentangle the interactions between $\mathrm{N}$-form of nutrition and pests and pathogens (Fig. 6).

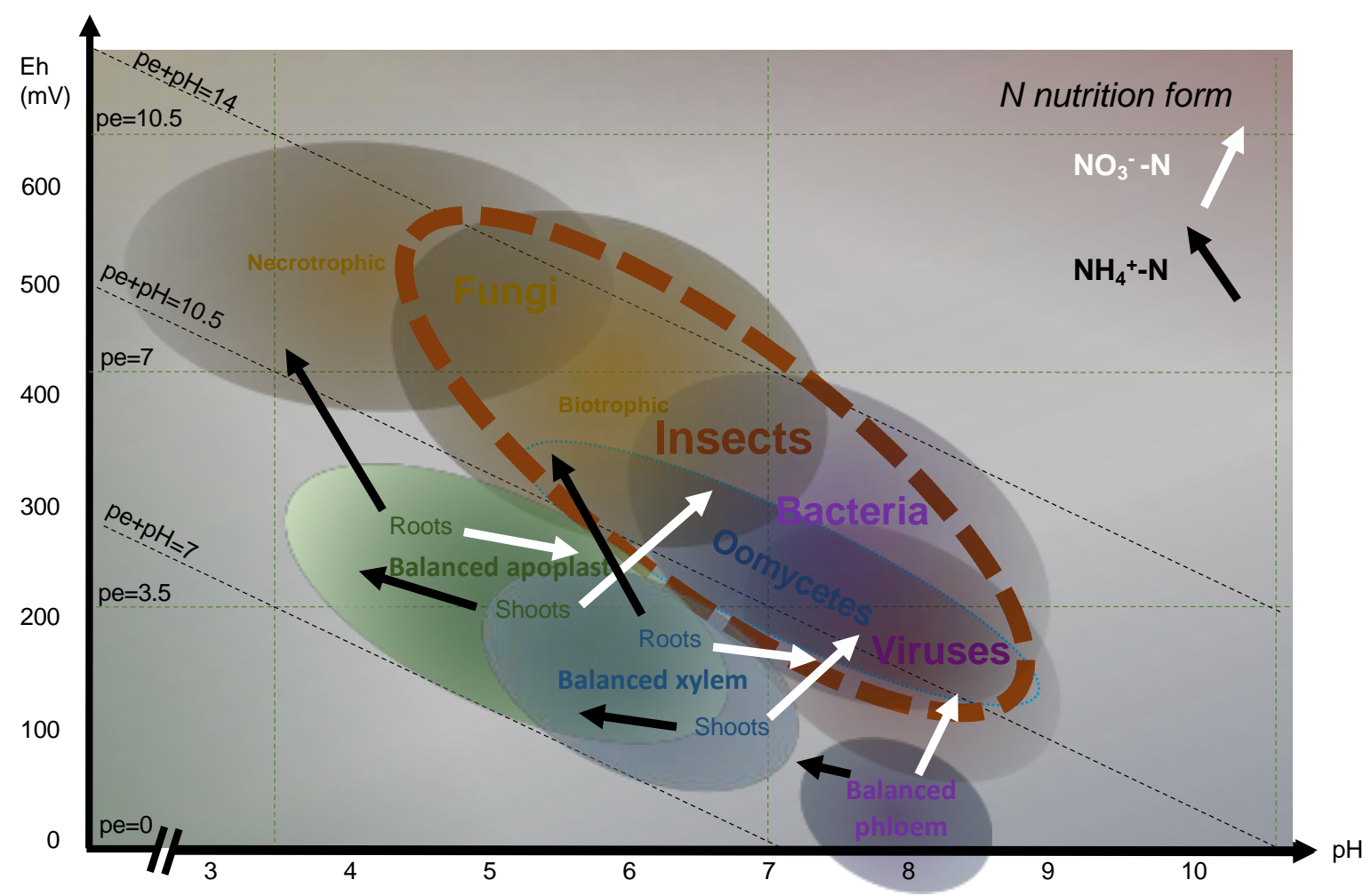

Fig. 6: Impact of $N$-form of nutrition, creating unbalanced redox conditions in plant parts ( $p H$-Eh map) in relation to optimum zones where the main groups of pathogenic microorganisms and pests can thrive. $\mathrm{NH}_{4}^{+}$ absorption (red arrows) leads to plant acidification, reduction (decreased pe+pH) of shoots but oxidation of roots. $\mathrm{NO}_{3}^{-}$absorption (yellow arrows) leads to plant alkalization, with shoots oxidation and roots reduction (Table 9). More generally, absorption of cation leads to acidification and absorption of anion leads to alkalization, as biochemical and biophysical stat mechanisms maintain stat status in the plant. However, nitrogen as a remarkadely stronger impact than other elements as $\mathrm{NH}_{4}{ }^{+}$and $\mathrm{NO}_{3}{ }^{-}$amount to $80 \%$ of the total anions and cations assimilated by plants (Marschner 1995).

By considering the type of pests and the part of the plant they infect first, we present clear patterns of disease severity (Huber and Watson 1974) that are in accordance with local Eh-pH conditions induced by N-form of nutrition:

- Soil-borne fungi that penetrate plants from the roots (Rhizoctonia spp., Fusarium spp., Armillaria spp., Sclerotinia spp. spp., Helminthosporium spp., Cercosporella spp., Thielavopsis spp., etc.) are decreased by nitrate and increased by ammonium (14 cases out of 16). This is in agreement with increased root $\mathrm{pH}$ and decreased root Eh by nitrate nutrition given that these fungi thrive at low $\mathrm{pH}$ and high Eh, and that ammonium nutrition leads to strong rhizosphere acidification. In contrast, soilborne fungi increased 
by nitrate nitrogen and actinomycetes such as Gaeumannomyces spp. and Streptomyces spp. are reduced by ammonium.

- Fungi of aerial parts and xylem-apoplast (Poria $=$ Stenocarpella spp., Verticillium spp.) are increased by nitrate and decreased by ammonium (4 cases over 4$)$. This is in accordance with lower Eh in aerial parts of ammonium-fed plants.

- Soil-borne oomycetes are either decreased by nitrate and increased by ammonium (Aphanomyces spp., Phytophthora spp.: 3 cases out of 3 ) or increased by nitrate and decreased by ammonium (Pythium spp.: 2 cases out of 2). This is in agreement with the facts that zoospore's germination is optimal for this pathogen at high pH of 7-8 (Davet 2004). Likewise, Aphanomyces spp. infection is the most severe at low soil pH (<6.5; Payne et al. 1994). Finally, zoospores of Phytophthora palmivora are anodotactic while those of Pythium aphanidermatum are cathodotactic (van West et al. 2002).

- Virus-like diseases are decreased by ammonium application (5 cases out of 6) while they are increased under nitrate nutrition ( 2 cases out of 2). This confirms that the acidification and reduction of aerial parts of the plant under ammonium nutrition, while many viruses require alkaline and oxidized conditions.

- Foliar and vascular bacterial pathogens (Pseudomonas spp., Erwinia spp., Corynebacterium spp.) are increased by nitrate application (4 cases out of 5) consistent with the increased $\mathrm{pH}$ related to nitrate nutrition, where most pathogenic bacteria thrive at high $\mathrm{pH}$.

- Nematode galls are increased by nitrate and decreased by ammonium nutrition (2 cases out of 2$)$. This confirms an increased root $\mathrm{pH}$ by nitrate fertilization (and inversely acidification by ammonium) and that Heterodera glycines is favored by high $\mathrm{pH}$ (Pedersen et al. 2010).

Similar conclusions can be drawn from the review by Huber and Thompson (2007). These authors reported increased disease with nitrate and decrease with ammonium nutrition of air-borne fungi such as M. oryzae, Alternaria macrospora, Monilinia vaccinia-corymbosi, etc., viruses and nematodes (Pratylenchus penetrans), and a decrease with nitrate. Ammonium nutrition of soil-borne fungi (Fusarium spp., Rhizoctonia spp., etc.) had the opposite effect. Thus, this dynamic and spatialized Eh-pH perspective can help decipher multiple contrasting interactions. For instance, in winter wheat, foliar and ear disease severity were positively associated with plant $\mathrm{N}$ uptake, use of mineral fertilizers, use of low leaf phenolic-flavonoid concentration, and short-straw variety "Solstice" (overall consistant with oxidized growing conditions in plants). In contrast, severity of the same diseases were negatively associated with the inputs of composted farm yard manure, leaf phenolic-flavonoid concentrations, and use of the long-straw variety "Aszita" which is rich in the phenols and flavonoids that maintain plants in a reduced condition (Rempelos et al. 2020). act on herbivores are altered by nitrogen fertilization, and herbivorous insects can distinguish plants receiving different nitrogen applications. Nitrogen fertilization results in higher occurrence and more crop damage from herbivorous insects by reducing plant resistance, and also increases sucking pests in 55\% of the studies (Shah 2017). This is in agreement with an increase in Eh and $\mathrm{pH}$ conditions in nitrate-fed plants. This Eh-pH 
homeostasis perspective could also be used to analyze the incidence of insect pests under mineral vs organic fertilizations (Altieri and Nicholls 2003).

\section{Micronutrients and plant-pest interactions in a Eh-pH perspective}

1055

1056

1057

1058

1059

1060

1061

1062

1063

1064

1065

1066

1067

1068

1069

1070

1071

1072

1073

1074

1075

1076

1077

1078

1079

1080

1081

1082

1083

1084

1085

1086

1087

1088

1089

Manganese is a good illustration of the benefit in considering Eh-pH to decipher relations between mineral nutrition and plant pests. Mn absorption is strongly influenced by soil-rhizosphere Eh-pH conditions, and is soluble only in its reduced form $\left(\mathrm{Mn}^{2+}\right)$, at low pe+pH. Mn has a tremendous impact on plant Eh-pH. Of central importance are its structural, redox and electron transport roles in photosynthesis, which results in the splitting of water and electron harvesting during the light reaction. Aside from Mn superoxide dismutase and a few Mn containing enzymes, Mn functions primarily as an activator of enzymes, including dehydrogenases, transferases, hydroxylases and decarboxylases (Thompson and Huber 2007).

Due to its role in plant Eh-pH regulation, it is not surprising that Mn availability reduces diseases in $89 \%$ of the cases (reviewed by Thompson and Huber (2007)). All the conditions leading to Mn reduction and, thus to its increased availability, decreased the development and severity of pathogenic fungi such as Gaeumannomyces graminis and $M$. oryzae. Interestingly, these pathogens possess the ability to oxidize $\mathrm{Mn}$, and their virulence depends on this capacity. Mn oxidation was, thus, highly correlated with fungal virulence and disease development (Thompson and Huber 2007). The battle for Mn between host and bacterial pathogens, in relation to oxidative stress, was, indeed, a major determinant defining the outcome of infections (Juttukonda and Skaar 2015).

Other essential micronutrients in redox regulation have a strong impact on a large range of pests. Examples are sulfur (Bloem et al. 2005), copper and boron, which were reported to decrease diseases in 93 and $91 \%$ of the studied cases, respectively (Datnoff et al. 2007).

The first-row transition metals - manganese $(\mathrm{Mn})$, iron $(\mathrm{Fe})$, cobalt $(\mathrm{Co})$, nickel $(\mathrm{Ni})$ and copper $(\mathrm{Cu})$ - provide the necessary redox and catalytic activity for many important biological processes (Ranieri et al. 2001; BárcenasMoreno et al. 2011; Gerwien et al. 2018). A process aptly named 'nutritional immunity' makes the host actively sabotage and counteract metal uptake by microorganisms and it can also fight invaders by deploying toxic levels of certain metals. Iron, $\mathrm{Cu}$ and $\mathrm{Mn}$, for example, are intrinsically toxic via Fenton chemistry (generation of oxygen radical species from hydrogen peroxide, catalyzed by the metal), leading to oxidative damage to the microbes at high metal concentrations (Gerwien et al. 2018). Finally, silicon, which has been reported to play an important role in resistance to fungal and bacterial diseases, and to herbivory (Epstein 1994; Fauteux et al. 2005; Sakr 2016; Liu et al. 2017), is also known to improve antioxidant capacity and redox homeostasis (Manivannan et al. 2018; Soundararajan et al. 2018). For example, silicon induces resistance of cassava to bacterial blight by altering antioxidant enzyme activity (Njenga et al. 2017).

\section{Revisiting pathogenicity and virulence in an Eh-pH perspective}

The Eh-pH perspective described herein provides a simple answer to the question "what makes commensal or opportunistic microorganisms become pathogenic?" The answer is that "A commensal or opportunistic 
microorganism becomes pathogenic when it encounters or can develop Eh-pH niches favorable for its development".

This hypothesis is supported by the fact that $\mathrm{pH}$ has now been recognized as a key factor in reducing fungal pathogenicity (Fernandes et al. 2017). In addition, cellular redox balance may serve as an inducer for the defense-related genes, including pathogenesis-related proteins (Foyer 2005). Oxalic acid indirectly aids Sclerotinia sclerotiorum pathogenicity by acting as a signaling molecule via manipulation of host ROS (Williams et al. 2011). Furthermore, ROS and redox regulation are also involved in the perception of pests and activation of plant defense. For instance, mitogen-activated protein kinase cascade, involved in pattern-triggered and effector-triggered immunity, is activated and regulated by ROS (Bigeard et al. 2015; Liu and He 2017).Indeed, the Rice Yellow Mottle Virus-encoded viral suppressor of RNA silencing P1 is a protein with redox-dependent flexibility (Gillet et al. 2013).

It can also be hypothesized that the virulence of a pathogen is related to its ability to alter and sustain host plant Eh-pH to its benefits despite the plant attempts to make it unfavorable, especially during the oxidative burst in the hypersensitive response (Torres et al. 2006). This is observed with Sclerotinia sclerotorium and Botrytis cinerea through oxalic acid production (Mbengue et al. 2016; Wang et al. 2016), or in bacteria through production of thiol antioxidants such as GSH and detoxification enzymes that consume ROS (Reniere 2018). Fungal $\mathrm{pH}$ modulations of the host environment regulate an arsenal of enzymes to increase fungal pathogenicity. This arsenal includes genes and processes that compromise host defenses, contribute to intracellular signaling, produce cell wall-degrading enzymes, regulate specific transporters, induce redox protectant systems, and generate factors needed by the pathogen to effectively cope with the hostile environment within the host (Alkan et al. 2013). The ability of the pathogen to actively increase or decrease its surrounding $\mathrm{pH}$ allows it to select the specific virulence factor, out of its vast arsenal, to best fit a particular host (Prusky and Yakoby 2003).

The evolution of pathogenicity towards novel hosts may be based on traits that were originally developed to ensure survival in the microorganism's original habitat, including former hosts (Van Baarlen et al. 2007). An EhpH perspective could help understand cross-kingdom host jumps or why and how pests can expand their host range. This perspective can also provide new insights on the "disease triangle" that integrate pathogenicity, host susceptibility, and environment. This can be done by stating that compatible interactions between a pathogen and a host will only result in disease symptoms when environmental conditions are also fulfilled (Van Baarlen et al. 2007). This review suggests that Eh-pH are major determinants of environmental conditions impacting pest-host interactions. plants in such situations; however, they may become detrimental when Eh-pH conditions change (especially increase in $\mathrm{pe}+\mathrm{pH})$ to alter their interactions. This could be the case for Cyanobacteria which exhibit characteristics of higher plants (photosynthetic organisms) as well as bacteria. These bacteria are able to reduce the effect of salinity by producing extracellular polysaccharide or compatible solutions, increase rice seed germination in drought situations, and remove pollutants (heavy metals and pesticides) from soil and water 
compounds efficiently in addition to releasing various enzymes, competing for rhizosphere space and activating plant defense responses by interacting with plant roots. All these features represent an exploitable strategy against pests in agriculture (Singh et al. 2016). In the event of soil oxidation, however, this group of bacteria can contribute to iron starvation of plants because Cyanobacteria require large amounts of iron and have developed very efficicent mechanisms for iron uptake. They are very competitive with plants for this essential nutrient element (Kranzler et al. 2013).

\section{Revisiting energy allocation and growth or defense trade-off with an Eh-pH perspective}

The plant immune system should be tunable because the immune response is costly, making unnecessary activation a burden on plant fitness (Nobori and Tsuda 2019). An Eh-pH approach may provide a new perspective on the growth versus defense trade-off in plants as reviewed by Huot et al. (2014). A model of plant energy allocation under various conditions is proposed in Fig. 7, based on the Eh-pH perspective.

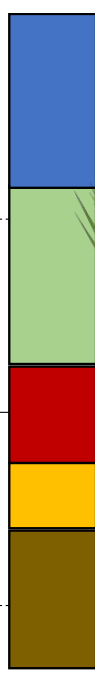

A.1

Balanced soil

Healthy plant

Balanced plants

High soil inputs

\section{Exploitative species}

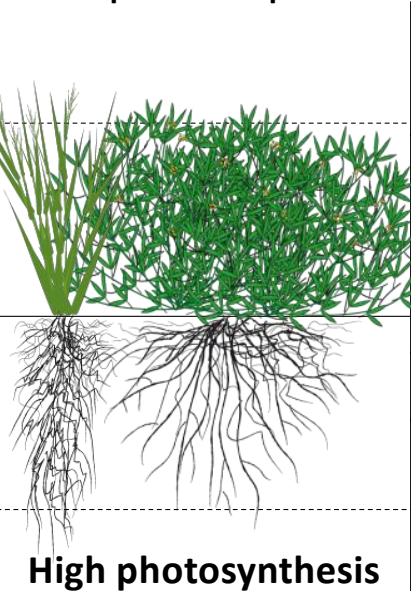

High photosynthesis

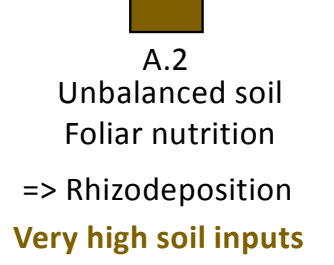

\section{Conservative species}

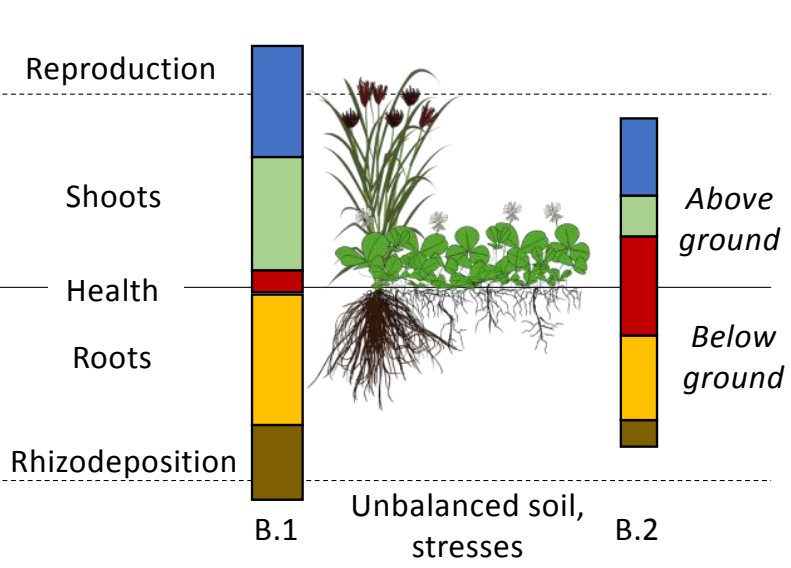

$=>$ limited photosynthesis

$$
\begin{aligned}
& \text { After attack } \\
& \Rightarrow \text { Health } \\
& \Rightarrow \text { Root system }
\end{aligned}
$$

Very low soil inputs

Fig. 7. Hypothesized model of energy allocation to reproduction, growth, health and rhizodeposition as a function of growing conditions. The energy investment distribution and aboveground-belowground interactions in this Fig. vary with plant strategies. A1: Under optimal soil conditions, the high energy produced by very efficient photosynthesis permits a balanced distribution of energy between vegetative growth, reproduction, health and root exudation, with the latter "feeding" the soil microorganisms. High amounts of exudates are released in the rhizosphere, but the high vegetative growth increases photosynthetic capacity, and thus energy production in a very sustainable cycle. Energy rich plants (balanced $\mathrm{pH}$, Eh and $\mathrm{pe}+\mathrm{pH}$ ) are not attractive to pests and are able to sustain interactions unfavorable to pathogens since they accumulate secondary metabolites and also are not attractive to insects. A2: When soil imbalance is (partially) compensated for by efficient fertilization (especially through foliar application of elements in an accessible form), high photosynthesis can be 
achieved. In order to restore the necessary soil balance, plants allocate a higher percentage of photosynthetic products to root exudation that selects and feeds a rich and balanced microflora. However, deficiency in various nutrients, including micronutrients, increases exudation of sugars, amino acids and phenolics (Cakmak and Marschner 1988; Carvalhais et al. 2011), at the expense of resources needed by the plant for growth and reproduction. B1: When photosynthesis is limited by various abiotic stresses (low light, extreme temperature, or soil imbalance that leads to nutrient deficiency, toxicity, etc.), energy production is low. In the absence of a pest, the available energy is mainly allocated to shoot and root growth and reproduction, with less, rhizodeposition to alter soil conditions favorable for plant health. The low energy allocated to plant health leads to high $\mathrm{pH}$ or high pe+pH and makes the plant attractive to pests and susceptible to pathogens. B2: Upon pest attack, the energy available for the plant is further decreased due to the reduction of photosynthetic activity, reduction of photosynthetic leaf tissues surrounding necrotic lesions, and reorientation of plant metabolism by the pathogen (Bastiaans and Kropff 1993; Berger et al. 2007). The plant then allocates most of its energy towards pest containment which limits its vegetative growth and, as a consequence, its photosynthetic capacity further. In a vicious circle, lower photosynthesis increases plant Eh-pH imbalance to increasing its susceptibility to pests.

This model is based on a series of observations. First, the spatial variability of Eh-pH in plants is consistent with a new perspective of defense predicting that the allocation of defensive chemistry within a plant is a function of tissue or organ value in terms of fitness. In other words, tissues with higher predicted value (young leaves with high photosynthetic activity, thus lower Eh-pH, have significantly higher concentrations of defensive chemicals compared to less valuable older tissues (McCall and Fordyce 2010). Second, ruderal plants growing on highly disturbed soil, are anticipated to spend most of their energy in reproduction rather than in mutualism (rhizodeposition). Competitor plants are expected to invest their energy mainly in growth but also in defense (health) and mutualist microorganisms. At the end of the spectrum, stress tolerators growing in soil with low disturbance are anticipated to primarily invest their energy in pest defense and feeding mutualist microorganisms (De Deyn 2017).

Under favorable soil conditions, the plant traits that govern carbon and nutrient exploitation generally dominate. These traits include fast growth, low C:N root:shoot ratio, low secondary metabolite content, short lifespan, and short litter residence time (De Deyn et al. 2008). Plants having such a strategy regarding acquisition, use and conservation of nutrients, are regarded as exploitative plants (Guyonnet et al. 2018a). Where soil resources (nutrients, water, oxygen, $\mathrm{pH}$ ) limit growth, plant traits that govern carbon and nutrient conservation generally dominate and are characterized by slow growth, high C:N root:shoot ratios, high secondary metabolite content, long (organ) lifespan and long litter residence time (De Deyn et al. 2008). These species exude less carbon in the rhizosphere but the exudate composition is different. Such species are regarded as conservative species. Under stress conditions such as drought, exploitative species reduce their growth and root exudation faster than conservative species to benefit from mycorrhizal symbiosis and increased fungal abundance. Upon long termextreme stress, conservative species are expected to reduce their growth, exudation and transfer of $\mathrm{C}$ to microbes and thereby impacting mycorrhizal symbiosis. Under similar conditions, exploitative species will respond by root death, reduced growth and less root exudation and $\mathrm{C}$ transfer to microbes. On termination of stress, conservative species, although they have unaltered exudate quality, will resume $\mathrm{C}$ transfer to microbes, re- 
establish mycorrhizal symbiosis, and slowly regrow. Despite altered root exudate quality, exploitative species will transfer high amounts of $\mathrm{C}$ to microbes, favor Plant Growth Promoting Rhizobacteria and recreate a high bacterial abundance. This permits rapid mineralization of dead roots, microbes and native soil organic matter that releases large amounts of $\mathrm{N}$ and accelerates regrowth (Williams and de Vries 2019). All this illustrates the strong interplay between roots and the soil microbiome.

\section{Eh-pH in the rhizosphere: interplay between roots and microbiota}

1202

On the asssumption that homeostasis is a focal point of ecology and evolution (Giordano 2013), the concept of Eh-pH homeostasis could bring an interesting perspective of soil-plant-microorganism interactions. In all ecosystems, plants transform the surrounding soil to make and maintain a habitat more favorable for growth (Marschner 1995). To this objective, plants shape the microbiome composition by selecting for specific microorganisms from the total pool of microorganisms in the bulk soil. These are then assembled into communities in the rhizosphere (Berg and Smalla 2009; Dini-Andreote and Elsas 2013). On the other hand, bacteria have developed various adaptation strategies to thrive in different rhizosphere niches (Jacoby et al. 2017). Microbial communities in the rhizosphere of different plant species growing on the same soil are often different, and some plant species can create similar communities in different types of soil. Even within species, different genotypes can develop distinct microbial communities in their rhizosphere. This suggests that plants are able to shape the composition of the microbiome in their rhizosphere (Berendsen et al. 2012), in such a way that both microbial density and activity in the rhizosphere are much higher than in bulk soil (Paungfoo-Lonhienne et al. 2010; Marschner 2011). Since root exudates play a key role in the establishment of plant-microorganisms interactions (Guyonnet et al. 2018a; Nobori and Tsuda 2019), plants probably shape common microbial communities as a result of these exudates (primary and secondary metabolites). Those that come from plant photosynthates are rich nutrient sources and include carbohydrates, organic acids and amino acids (Paszkowski 2006). Soil pe $+\mathrm{pH}$ contributes significantly to determine soil enzyme activities and differences in microbial composition and function (Wang et al. 2020).

Parameters such as $\mathrm{pH}$, redox, ionic strength, water potential, and the concentration of nutrients and organic compounds are different in the rhizosphere compared to bulk soil (Jones et al. 2004). Under imbalanced soil conditions, plants alter rhizosphere Eh-pH towards neutral conditions (Krasil'nikov 1958; Hinsinger et al. 2003; Husson 2013). They do this through root exudates, as a result of passive diffusion or release under active processes for a specific purpose (Fischer et al. 1989; Jones et al. 2004). In both cases, plants rely strongly on microorganisms to alter and buffer rhizopshere soil Eh-Ph. Microorganisms are: i) adapted to specific Eh-pH conditions (and their fluctuations), ii) able to sense redox signals (redox-taxis), and iii) able to alter and adapt Eh and $\mathrm{pH}$ of their surrounding environment to their requirements to a much greater extent than other living organisms (Krasil'nikov 1958; Rabotnova and Schwartz 1962; Alexandre and Zhulin 2001; Pidello 2014). Indeed, soil bacteria are able to create networks with tiny electronic connections between electron donors and acceptors which is critical to electron transfer via electrical currents ( $\mathrm{Li}$ et al. 2017). These networks enable microbial communities to rapidly eliminate electrons coming from their metabolic processes and transport them 
2015). Under well-structured and biologically active soils, water bounding can be expected, knowing that bound water has a catalytic action and is known to facilitate electron and proton transfers (Ball 2008). These redox reactions between connections are also facilitated through soil electrical conductivity which is related to nutrient content, salinity, organic matter, pyrogenic carbon, cation exchange capacity, residual humidity, soil texture and soil compaction (Husson 2013). Electrical currents have actually been measured between roots and arbuscular mycorrhizae (Berbara et al. 1995).

When facing biotic stresses, plants react by changing the chemistry of their root exudates to assemble healthpromoting microbiomes (Rolfe et al. 2019). Besides, plant roots alter soil structure, aeration and humidity to create microhabitats which can be seen as many Eh-pH niches (Krasil'nikov 1958; Fischer et al. 1989) compatible with microorganisms of various Eh-pH requirements. The joint activity of roots and microbes promotes physico-chemical heterogeneity in the rhizosphere with its spatial and temporal diversity in the local soil microhabitat (Dini-Andreote and Elsas 2013). While stochastic community assemblies dominate in homogeneous environments, deterministic community assembly processes are the rule in heterogeneous environments, hence, creating selective pressure for microorganisms (Dini-Andreote et al. 2015).

Plant roots, microbes and earthworms determine soil aggregation, especially near the surface of their biopores, either by enhancing aggregate diversity or by its homogenization. Roots lead to the formation of subpolyeders and shrinkage-induced cracks due to water uptake while earthworms form tiny platy and sheared structures because of their intermittently swollen body shape (Haas and Horn 2018). Close to the biopore surface $(<1 \mathrm{~mm})$, roots have an acidifying effect while earthworms have an alkalizing one. The interaction of both lead to neutral to slightly acid $\mathrm{pH}$ and a neutral Eh at approximately $400 \mathrm{mV}$. Within the microaggregates, roots lead to higher Eh $(600 \mathrm{mV})$ while earthworm activity leads to a more neutral Eh around 400-450 mV (Haas and Horn 2018). In return, microorganisms further alter and buffer Eh-pH conditions, especially in the rhizosphere which is a hotspot of biological activity (Krasil'nikov 1958). Hence, a direct effect of microorganisms is achieved through the production of biofilms and indirectly through improvement of aggregation, stabilization of soil structure (thanks to bacterial polysaccharide and fungal glycoprotein glues), increased water retention (thanks to biological mesoporosity increase), and resistance against erosion that create a diversity of Eh-pH niches (Pidello 2014; Clocchiatti et al. 2020).

Improved Eh-pH conditions and, consequently, enhanced plant nutrition and health, lead to increased photosynthesis, plant production and root exudation to further favor microbial growth and diversity in a virtuous cycle (Fig. 8). This entire process of soil transformation starts from seed germination: germinating seeds profoundly modify their environment and their microbiota as they constitute important sources of nutritious exudates, a great part of which is volatile. Exudate production increases with the quantity of reserve substances stored in the seeds,; thus, it varies with seed size and is species-dependent (Davet 2004; Nelson 2018). Production conditions, age of the seed and storage conditions can lead to physiological differences between two genetically identical seed lots. Increased moisture content and storage temperature leads to oxidation, higher $\mathrm{pH}$ and loss of viability (Nagel et al. 2019). 
The 'lifestyle' of the plant needs to be considered in order to put all of this information into perspective. Conservative species exude more amino acids, while exploitative species exude more primary metabolites (sugar, organic acids) and this composition differential can be critical in regulating the plant's microbiota (Guyonnet et al. 2018b). By exuding more carbon into the rhizosphere, exploitative species attract more taxa in root tissues and in the rhizoplane (Root-Adhering Soil, RAS), and they stimulate more taxa involved in Soil Organic Matter (SOM) degradation by a "priming effect" mechanism. They select more specific SOM degraders, exclude consumers in the RAS and root inhabiting bacteria than conservative species, and they increase denitrifying activity in the RAS (Guyonnet et al. 2018b). Organic acids cause significantly greater increases than sugars do in the detectable richness of the soil bacterial community and lead to larger shifts in the composition of dominant taxa. The greater response of bacteria to organic acids may be due to the higher amounts of added carbon, solubilization of soil organic matter or shifts in soil pH (Shi et al. 2011). Inversely, the root exudation pattern and root respiration are altered by microorganisms such as mycorrhizae or bacteria (Jones et al. 2004; Korenblum et al. 2020).

These interactions occur at different time scales, at medium or long term in the process of soil aggregation and weathering although they are also important at relatively short-term. Loss of $\mathrm{C}$ from the plant to the rhizosphere is a rapid process: photosynthetically fixed $\mathrm{C}$ can be detected in the rhizosphere in less than 1 hour after photosynthetic fixation and reaches maximum exudation rates after $3 \mathrm{~h}$. Likewise, microbial turnover of root exudates in the soil is very rapid, with a half-life of between 0.5 and $2 \mathrm{~h}$ for most sugars, amino acids and organic acids (Jones et al. 2004).

Endophytic microbes (mostly bacteria and fungi) present on asymptomatic plants have also been shown to: (i) obtain nutrients in soils and transfer them to plants in the rhizophagy cycle and other nutrient-transfer symbioses; (ii) increase plant growth and development; (iii) reduce oxidative stress of hosts; (iv) protect plants from diseases; (v) deter feeding by herbivores; and (vi) suppress growth of competitor plant species (White et al. 2019). Plant roots can not only incorporate large organic molecules including proteins and DNA, but are also able to take up non-pathogenic microorganisms into root cells where they are degraded and used as as a nutrient source (Paungfoo-Lonhienne et al. 2010). This rhizophagy cycle is an oxidative process in plants for nutrient extraction from symbiotic microbes (White et al. 2019).

Root exudates drive the soil-borne legacy of aboveground pathogen infection (Yuan et al. (2018). After five generations of Arabidopsis thaliana inoculated aboveground with Pseudomonas syringae pv tomato, the causal agent of bacterial speck of tomato, bacterial communities of both rhizosphere and bulk soil were altered by the infection of this bacterial pathogen. These changes were the result of greater exudation of amino acids, nucleotides, and long-chain organic acids as well as the lower exudation of sugars, alcohols, and short-chain organic acids. The sixth generation of A. thaliana was grown on the same pathogen-conditioned soil but was uninfected by the bacterial pathogen. The sixth generation of the plant had increased levels of jasmonic acid (a defense-regulating phytohormone), and improved disease resistance compared with plants grown on controlconditioned soil (five generations of A. thaliana uninfected by Pst). This clearly demonstrates the capacity of 

exposure to aboveground pathogens to the benefit of subsequent plant generations (Yuan et al. 2018).

The rhizosphere microbiome results from an interplay between soil and seed microbiota, beneficial and pathogenic microorganisms colonizing aerial parts of plants, and root exudation; all of which appears to be soil, but soil is in part derived from the activity of plants (Fig. 8) since they supply organic matter and play a pivotal role in weathering rocks and minerals (Lambers et al. 2009).

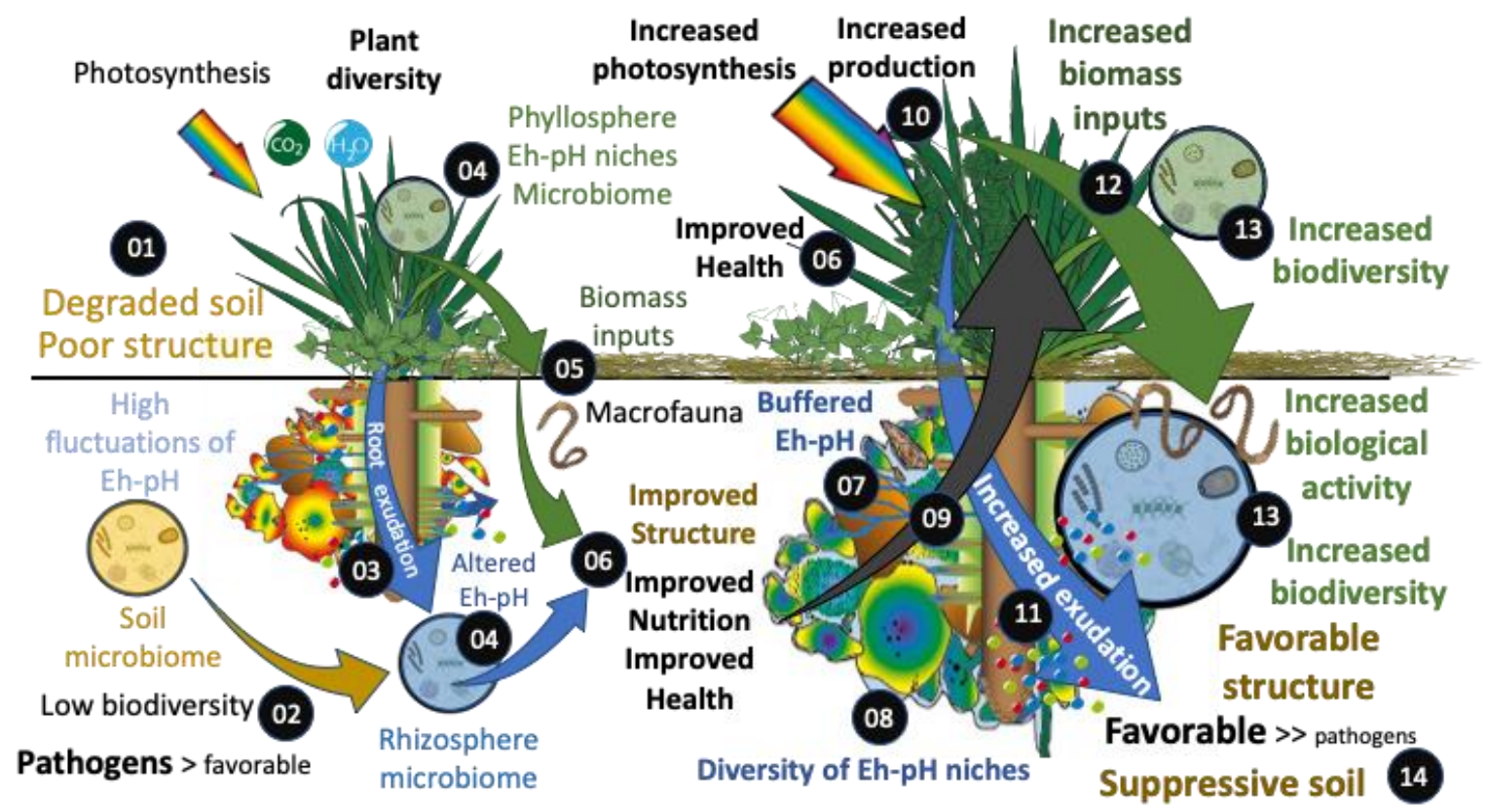

Fig. 8: Schematic presentation of the soil-plant-microorganism system showing the central role of photosynthesis by plant that provides the "fuel" for soil system regeneration. On degraded soils (01), poor structure and high Eh-pH fluctuations lead to low diversity of the soil microbiome, with pests dominating beneficial organisms (02) to result in poor plant growth. As a consequence, plants have limited capacity and energy to sustain an efficient pest or pathogen defense system, leading to poor plant health. Increasing photosynthetic activity by various means leads to increased root exudation (03) that alters Eh-pH and allows the development of a diversity of microorganisms in the rhizosphere and phyllosphere (04). The inputs of biomass on the soil surface from decaying plant parts create a litter (05) that, promotes the development of active macrofauna. Together with the active macrofauna, feeding on root exudates microorganisms in the rhizosphere improve soil structure, plant nutrition and plant health (06). The improved soil structure and active microbiota buffer the Eh-pH, both in soil and plants (07) to create a diversity of Eh-pH niches (08) and food supplies for microorganisms. All of this activity favors the completion of major biogeochemical cycles and increases plant defense against pests. Improved soil structure, plant nutrition and health (09) result in increased photosynthesis and biomass production (10). Consequently, both root exudation (11) and biomass inputs on the soil surface 
soil aggregation, plant nutrition and plant health in a virtuous cycle. Beneficial organisms largely dominate pests, leading to suppressive soils (14).

Are balanced and diverse Eh-pH niches hosting a highly diverse microbiome the key determinant to soil suppressiveness?

Competitive interactions in soil microbial communities are regarded as the major driving factor of general soil suppressiveness. To infect root tissue, pathogens have to compete with members of the rhizosphere microbiome for available nutrients and microsites (Chapelle et al. 2016). In disease-suppressive soils, pathogen activity is strongly restricted by specific rhizosphere microorganisms. For instance, the rhizosphere microbiome of sugar beet seedlings grown in a soil suppressive to the fungal pathogen Rhizoctonia solani showed that Oxalobacteraceae, Burkholderiaceae, Sphingobacteriaceae and Sphingomonadaceae were significantly more abundant in the rhizosphere upon fungal invasion and that stress-related genes (ppGpp metabolism and oxidative stress) were upregulated in these bacterial families (Chapelle et al. 2016). It was postulated that the pathogenic fungus induces directly or via the plant, stress responses in the rhizobacterial community that lead to shifts in microbiome composition and to activation of antagonistic traits that restrict pathogen infection. Several rootcolonizing microorganisms are known to improve the plants response to pathogens (Meisner and De Boer 2018). Upon pest attack, plants are able to stimulate protective microorganisms and enhance microbial activity that suppresses pests in the rhizosphere (Berendsen et al. 2012). Natural antibiotics are weapons in the microbial warfare in the rhizosphere that are integral to plant health (Cha et al. 2016). Plant response to increased pathogen abundance depends on the microbial community colonizing the root, which is affected by the amount and composition of rhizodeposits. For example, iron-mobilizing coumarins exudated by $A$. thaliana shape their root bacterial community by inhibiting the proliferation of a relatively abundant Pseudomonas species via a redoxmediated mechanism (Voges et al. 2019). Redox-active phenazine compounds also play a role in the persistence and survival of Pseudomonas spp. in the rhizosphere and, inversely, plant-beneficial phenazine-producing Pseudomonas spp. are proficient biocontrol agents of many soilborne pathogens (Biessy and Filion 2018). Melatonin, an amphiphilic antioxidant produced by cellular organisms able to scavenge both oxygenated and nitrogenated compounds, may decrease the deleterious physiological effect of various abiotic stresses through modulation of antioxidative enzymes and enhancement of organic acid anion exudation. In addition it may differentially modify some bacterial and fungal communities (Pisoschi and Pop 2015; Zhang et al. 2017; Madigan et al. 2019).

Redox states affect substrate availability and energy transformation and, thus, play a crucial role in regulating soil microbial abundance, diversity, and community structure (Song et al. 2008). Redox potential fluctuations are common in soils, and microbial community acclimation or avoidance strategies for survival shape microbial community diversity and biogeochemistry (DeAngelis et al. 2010). By characterizing redox-related soil microbial communities along a river flood plain continuum, Song et al. (2008) observed that, microorganisms, in general were highly abundant, diverse, and distributed more evenly in the oxic layers than the anoxic ones. The lower diversity in the anoxic than the oxic soils was primarily attributed to differences in oxygen availability in these soils. The decrease in abundance with increasing oxygen and substrate limitation, however, was 
energy demanding than maintenance (Song et al. 2008). Although indigenous soil bacteria are highly adapted to fluctuating redox regimens and generally possess physiological tolerance mechanisms allowing them to withstand unfavorable redox periods, soil bacterial communities loose significant diversity under sustained or frequent anoxic conditions (Pett-Ridge and Firestone 2005). pH is also a major driver of microorganism diversity in soil, and appears to be more important than nutrients in shaping bacterial communities in agricultural soils, including their ecological functions and biogeographic distribution (Wang et al. 2019). Fast changing Eh-pH conditions are therefore expected to be detrimental to biological activity and diversity. Soil structure resulting from the interactions of plant roots, associated macrofauna and microbial activity to strongly impact Eh-pH dynamics, appears to be a key determinant of soil health.

The loss of organic matter and degradation of soil structure due to soil tillage (Reicosky et al. 1997; Johannes et al. 2017) lead to low buffering capacity and thus, strong fluctuations in soil Eh and pH (Husson 2013). Fiedler et al. (2003) measured a pronounced decrease in soil Eh (-100 to $-200 \mathrm{mV} \cdot \mathrm{h}^{-1},-800 \mathrm{mV}$ in 3 days) as a result of water saturation following precipitation events, and an inverse raise in soil Eh in drying soils. Together with mean soil Eh, strong fluctuations of soil $\mathrm{pH}$ occur with changes in soil humidity, especially upon saturation (Tano et al. 2020). These fast-changing conditions strongly affect microbial populations and growth. Under rapidly fluctuating conditions, microbial populations can be periodically activated and inactivated, which, in turn, quickly alters the nature and rate of key biogeochemical transformations (Pett-Ridge and Firestone 2005). Physiological responses to stress have costs at the organismal level that can result in altered ecosystem-level C, energy, and nutrient flows. These large-scale impacts result from direct effects on active microbes' physiology and through stability of the active microbial community (Schimel et al. 2007). Plants can not always adapt to fast-changing Eh-pH conditions and, consequently, face multiple stresses that render them susceptible to multiple pests and pathogens.

Inversely, under well-structured soils that are rich in organic matter with active root systems, a large diversity of Eh-pH niches can harbor a diverse and highly active biological community. This provides essential ecological services that allow plants to sustain their Eh-pH homeostasis. For instance, plant- and root-associated microorganisms enhance plant mineral nutrition and carbon cycling through redox alteration (Marschner 1995; Schimel and Schaeffer 2012; Xi et al. 2016; Jacoby et al. 2017). The biogeochemical cycles of carbon, nitrogen, sulfur, and phosphorus appear to be driven by the "FeIII-FeII redox wheel" in dynamic redox environments (Li et al. 2012). Arbuscular mycorrhizal fungi improve redox homeostasis in rice through regulation of ROS scavenging activities that help the host release glutathione ( $\mathrm{Li}$ et al. 2020). Trichoderma species, are involved in redox processes that confer resistance to redox stresses and facilitate redox homeostasis (Cardoza et al. 2010; Singh et al. 2013). This beneficial effect is reduced by (oxidizing) abiotic stresses for Trichoderma harzianuminduced resistance to downy mildew in grapevine (Perazzolli et al. 2011).

Well-structured soils that offer a large range of Eh-pH niches and host a highly diverse microbial community, have been regarded as plant disease suppressive soils (Cook 2014; Löbmann et al. 2016). Oxygen gradients (in space and time) lead to the assembly of a microbial community that is dominated by populations that are able to endure in both aerobic and anaerobic conditions (Chen et al. 2017a). Effective oxygen consumption, combined 
with the formation of microaggregates, sustains the activity of oxygen-sensitive anaerobic enzymes and leads to the direction of unsorted redox processes (i.e. not following the "redox tower" that would cause ecological niches of prokaryotes that consume electron acceptors in a thermodynamically determined order), within and between populations (Chen et al. 2017a). Various ecological services can be simultaneously ensured at any time by the rich soil biodiversity in a balanced environment.

\section{Conclusions and future perspectives}

Although causality cannot be demonstrated with the available literature, the literature does report many spatiotemporal correlations between Eh-pH conditions and plant susceptibility, tolerance and resistance to pests across various stress conditions that could support our initial hypothesis that Eh-pH homeostasis is central to soil and plant health. The Eh-pH homeostasis model is strengthened by the fact that this model: i) represents a unifying paradigm that comprises a large range of processes in a very logical and consistent manner; ii) encompasses various other models in crop protection (priming-exhaustion, optimal defense theory, susceptibility-toleranceresistance, soil legacy, etc.); iii) enlightens our understanding of these processes without contradicting any observation or current knowledge; and, finally iv) provides a useful perspective to disentangle $\mathrm{G} \times \mathrm{E} \times \mathrm{M} \times \mathrm{P}$ interactions.

The new perspective this model proposes could help: i) plant pathologists and entomologists understand plantpathogen and plant-pest interactions, and develop new approaches to pest management; ii) epidemiologists and modelers refine their models; iii) breeders improve and accelerate breeding for improved plant resistance, adaptability and tolerance to various stresses, pests and pathogens; and enhance energy allocation between growth and defense in selected varieties; iv) plant nutrition specialists design advanced fertilizers adapted to $\mathrm{pH}$ Eh conditions of a given soil to meet the requirements of a given crop; and v) agronomists develop agroecological crop protection (ACP; Deguine et al. 2017) or biodiversity-based agriculture by developing ecosystem services provided by biological diversity based on a redesign of the farming system (Wezel et al. 2014; Duru et al. 2015).

Overall, an Eh-pH perspective could become a very powerful tool to develop a "one health approach" (Mackenzie and Jeggo 2019; Ratnadass and Deguine 2021) as the same parameters explain fundamental processes and could be used to characterize the "health" of soils (Husson et al. 2018b), plants (Husson et al. 2018a), animals and humans. This is consistent with the increasing recognition of the importance of Eh and $\mathrm{pH}$ homeostasis in health (Aoi and Marunaka 2014; Ursini et al. 2016; Kruk et al. 2019) and the role of microbiota and pathobiota in healthy and unhealthy host immune responses (Littman and Pamer 2011).

This review emphasizes the importance of jointly considering Eh and $\mathrm{pH}$ in further studies since most studies conducted to date disconnect these two interacting parameters. In order to accomplish this, improved measurement methods and other tools are needed to assess plant and soil Eh-pH conditions. These could include spectrometric methods to overcome limitations of electrochemical ones for plants and the use of bio-indicators as natural vegetation species to surmount problems related to the high spatio-temporal variability in soils. 
1461 Funding

1462 Not applicable

1463

1464 Conflicts of interest/competing interests

1465 The authors declare having no conflict of interest

1466

1467 Availability of data and material

1468 Not applicable

1469

1470 Code availability

1471 Not applicable

1472

1473 Compliance with ethical standards

1474 All authors read and approved the final manuscript

\section{References}

1477

1478

1479

1480

1481

1482

1483

1484

1485

1486

1487

1488

1489

1491

1492

1493

1494

1495

1496

1497

Aarti PD, Tanaka R, Tanaka A (2006) Effects of oxidative stress on chlorophyll biosynthesis in cucumber (Cucumis sativus) cotyledons. Physiol Plant 128:186-197. doi: 10.1111/j.1399-3054.2006.00720.x

Abdullah AS, Moffat CS, Lopez-Ruiz FJ, et al (2017) Host-multi-pathogen warfare: Pathogen interactions in coinfected plants. Front Plant Sci 8:1-12. doi: 10.3389/fpls.2017.01806

Agrios GN, Sonnack KD, Beattie L, Decicco E (2005) Plant pathology, Fifth. Elsevier Academic Press

Ah-Fong AMV, Kagda MS, Abrahamian M, Judelson HS (2019) Niche-specific metabolic adaptation in biotrophic and necrotrophic oomycetes is manifested in differential use of nutrients, variation in gene content, and enzyme evolution. PLoS Pathog 15:1-30. doi: 10.1371/journal.ppat.1007729

Ahmad N, Malagoli M, Wirtz M, Hell R (2016) Drought stress in maize causes differential acclimation responses of glutathione and sulfur metabolism in leaves and roots. BMC Plant Biol 16:1-15. doi: 10.1186/s12870-016-0940-Z

Alexandre G, Zhulin IB (2001) More than one way to sense chemicals. J Bacteriol 183:4681-4686. doi: 10.1128/JB.183.16.4681-4686.2001

Alkan N, Espeso EA, Prusky D (2013) Virulence Regulation of Phytopathogenic Fungi by pH. Antioxid Redox Signal 19:1012-1025. doi: 10.1089/ars.2012.5062

Alkhalfioui F, Renard M, Vensel WH, et al (2007) Thioredoxin-linked proteins are reduced during germination of Medicago truncatula seeds. Plant Physiol 144:1559-1579. doi: 10.1104/pp.107.098103

Allen DJ, Ort DR (2001) Impacts of chilling temperatures on photosynthesis in warm-climate plants. Trends Plant Sci 6:36-42. doi: 10.1016/S1360-1385(00)01808-2

Altieri MA, Nicholls CI (2003) Soil fertility management and insect pests: Harmonizing soil and plant health in agroecosystems. Soil Tillage Res 72:203-211. doi: 10.1016/S0167-1987(03)00089-8

Amtmann A, Troufflard S, Armengaud P (2008) The effect of potassium nutrition on pest and disease resistance 
in plants. Physiol Plant 133:682-691. doi: 10.1111/j.1399-3054.2008.01075.x

1501

1502

1503

1504

1505

1506

1507

1508

1509

1510

1511

1512

1513

1514

1515

1516

1517

1518

1519

1520

1521

1522

1523

1524

1525

1526

1527

1528

1529

1530

1531

1532

1533

1534

1535

1536

1537

1538

1539

Andrews JH, Harris RF (2000) The ecology and biogeography of microorganisms on plant surfaces. Annu Rev Phytopathol 38:145-180. doi: 10.1146/annurev.phyto.38.1.145

Anjum N a, Gill SS, Gill R, et al (2014) Metal/metalloid stress tolerance in plants: role of ascorbate, its redox couple, and associated enzymes. Protoplasma 251:1265-83. doi: 10.1007/s00709-014-0636-x

Anjum NA, Khan NA, Sofo A, et al (2016) Redox homeostasis managers in plants under environmental stresses. Front Environ Sci 4:210. doi: 10.3389/fenvs.2016.00035

Anuradha M, Narayanan (1991) Promotion of root elongation by phosphorus deficiency. Plant Soil 136:273-275

Aoi W, Marunaka Y (2014) Importance of $\mathrm{pH}$ homeostasis in metabolic health and diseases : Crucial role of membrane proton transport. Biomed Res Int 2014:ID598986. doi: 10.1155/2014/598986

Appel HM (1993) Phenolics in ecological interactions: The importance of oxidation. J Chem Ecol 19:1521-1552

Appel HM, Joern A (1998) Gut physicochemistry of grassland grasshoppers. J Insect Physiol 44:693-700

Appel HM, Martin MM (1990) Gut redox conditions in herbivorous Lepidopteran larvae. J Chem Ecol 16:32773290

Arabi MIE, Jawhar M (2002) The ability of barley powdery mildew to grow in vitro. J Phytopathol 150:305307. doi: 10.1046/j.1439-0434.2002.00751.x

Armijo G, Schlechter R, Agurto M, et al (2016) Grapevine pathogenic microorganisms: Understanding infection strategies and host response scenarios. Front Plant Sci 7:1-18. doi: 10.3389/fpls.2016.00382

Aubrey DP, Boyles JG, Krysinsky LS, Teskey RO (2011) Spatial and temporal patterns of xylem sap pH derived from stems and twigs of Populus deltoides L. Environ Exp Bot 71:376-381. doi: 10.1016/j.envexpbot.2011.02.006

Awasthi R, Bhandari K, Nayyar H (2015) Temperature stress and redox homeostasis in agricultural crops. Front Environ Sci 3:1-24. doi: 10.3389/fenvs.2015.00011

Babbar R, Karpinska B, Grover A, Foyer CH (2021) Heat-induced oxidation of the nuclei and cytosol. Front Plant Sci 11:1-16. doi: 10.3389/fpls.2020.617779

Backhausen JE, Scheibe R (1999) Adaptation of tobacco plants to elevated $\mathrm{CO}_{2}$ : influence of leaf age on changes in physiology, redox states and NADP-malate dehydrogenase activity. J Exp Bot 50:665-675. doi: 10.1093/jxb/50.334.665

Bahrun A, Jensen CR, Asch F, Mogensen VO (2002) Drought- induced changes in xylem pH, ionic composition, and $\mathrm{ABA}$ concentration act as early signals in field- grown maize (Zea mays L.). J Exp Bot 53:251-263

Baier M, Dietz KJ (2005) Chloroplasts as source and target of cellular redox regulation: A discussion on chloroplast redox signals in the context of plant physiology. J Exp Bot 56:1449-1462. doi: $10.1093 / \mathrm{jxb} / \mathrm{eri161}$

Ball P (2007) Bacteria may be wiring up the soil. Nature 449:388. doi: 10.1038/449388a

Ball P (2008) Water as an active constituent in cell biology. Chem Rev 108:74-108. doi: 10.1021/cr068037a

Balmer A, Pastor V, Gamir J, et al (2015) The "prime-ome": Towards a holistic approach to priming. Trends Plant Sci 20:443-452. doi: 10.1016/j.tplants.2015.04.002

Bárcenas-Moreno G, García-Orenes F, Mataix-Solera J, et al (2011) Soil microbial recolonisation after a fire in a Mediterranean forest. Biol Fertil Soils 47:261-272. doi: 10.1007/s00374-010-0532-2 
Bastiaans L, Kropff MJ (1993) Effects of leaf blast on photosynthesis of rice 2. Canopy photosynthesis. Netherlands J Plant Pathol 99:205-217. doi: 10.1007/BF01974665

1542

1543

1544

1545

1546

1547

1548

1549

1550

1551

1552

1553

1554

1555

1556

1557

1558

1559

1560

1561

1562

1563

1564

1565

1566

1567

1568

1569

1570

1571

1572

1573

1574

1575

1576

1577

1578

1579

Bateman D (1978) The dynamic nature of disease. In: JG H, EB C (eds) Plant Disease, An Advanced Treatise Vol. III How Plants Suffer from Disease. Academic Press, pp 53-83

Benada J (1966) The gradients of oxidation-reduction potentials in cereals and the dependance of obligate parasites on the redox potentials of the host tissues. Phytopathol Zeitschrift 55:265-269

Benada J (2012) Redox potential and pH in plants and their function in the mechanism of resistance to diseases and in plant physiology. A review. Agrotest fyto, s.r.o. Zemedelsky vyzkumny ustav Kromeriz

Benada J (2017) Measurement of redox potential and pH in plants and their function in the mechanism of plant resistance and in plant physiology. Int J Adv Res Electr Electron Instrum Eng 1111-1116. doi: 10.15662/IJAREEIE.2015.0501001

Benada J (1967) The distribution of redox potentials and $\mathrm{pH}$ values in the leaves of cereal tillers during the stem extension. Flora, Abt A, Bd 158:343-350

Bendix C, Lewis JD (2018) The enemy within: Phloem-limited pathogens. Mol Plant Pathol 19:238-254. doi: 10.1111/mpp. 12526

Benitez-Alfonso Y, Jackson D, Maule A (2011) Redox regulation of intercellular transport. Protoplasma 248:131-140. doi: 10.1007/s00709-010-0243-4

Berbara RLL, Morris BM, Fonseca HMAC, et al (1995) Electrical currents associated with arbuscular mycorrhizal interactions. New Phytol 129:433-438. doi: 10.1111/j.1469-8137.1995.tb04314.X

Berendsen RL, Pieterse CMJ, Bakker PAHM (2012) The rhizosphere microbiome and plant health. Trends Plant Sci 17:478-486. doi: 10.1016/j.tplants.2012.04.001

Berg G, Smalla K (2009) Plant species and soil type cooperatively shape the structure and function of microbial communities in the rhizosphere. FEMS Microbiol Ecol 68:1-13. doi: 10.1111/j.1574-6941.2009.00654.x

Berger S, Sinha AK, Roitsch T (2007) Plant physiology meets phytopathology: Plant primary metabolism and plant-pathogen interactions. J Exp Bot 58:4019-4026. doi: 10.1093/jxb/erm298

Bernacchi CJ, Leakey ADB, Heady LE, et al (2006) Hourly and seasonal variation in photosynthesis and stomatal conductance of soybean grown at future $\mathrm{CO}_{2}$ and ozone concentrations for 3 years under fully open-air field conditions. Plant, Cell Environ 29:2077-2090. doi: 10.1111/j.1365-3040.2006.01581.x

Berthelot E, Ducousso M, Macia J-L, et al (2019) Turnip Mosaic Virus is a second example of a virus using transmission activation for plant-to-plant propagation by Aphids. J Virol 93:1-11. doi: 10.1128/jvi.0182218

Bertrand PF (1976) Late season water deficits and development of Cytospora canker in French prune. Phytopathology 66:1318

Best RJ (1968) Tomato Spotted Wilt Virus. Adv Virus Res 13:65-146. doi: 10.1016/S0065-3527(08)60251-1

Best RJ, Samuel G (1936) The reaction of the viruses of tomato spotted wilt and tobacco mosaic to the pH value of media containing them. Ann Appl Biol 23:509-537. doi: 10.1111/j.1744-7348.1936.tb06108.x

Bhuyan MHMB, Hasanuzzaman M, Mahmud J Al, et al (2019) Unraveling morphophysiological and biochemical responses of Triticum aestivum 1 . to extreme $\mathrm{pH}$ : Coordinated actions of antioxidant defense and glyoxalase systems. Plants 8:1-18. doi: 10.3390/plants8010024

Bi JL, Felton GW (1995) Foliar oxidative stress and insect herbivory: Primary compounds, secondary 
metabolites, and reactive oxygen species as components of induced resistance. J Chem Ecol 21:15111530. doi: 10.1007/BF02035149

1582

1583

1584

1585

1586

1587

1588

1589

1590

1591

1592

1593

1594

1595

1596

1597

1598

1599

1600

1601

1602

1603

1604

1605

1606

1607

1608

1609

1610

1611

1612

1613

1614

1615

1616

1617

1618

1619

Biessy A, Filion M (2018) Phenazines in plant-beneficial Pseudomonas spp.: biosynthesis, regulation, function and genomics. Environ Microbiol 20:3905-3917. doi: 10.1111/1462-2920.14395

Bigeard J, Colcombet J, Hirt H (2015) Signaling mechanisms in pattern-triggered immunity (PTI). Mol Plant 8:521-539. doi: 10.1016/j.molp.2014.12.022

Bignell DEE (1984) Direct potentiometric determination of redox potentials of the gut contents in the termites Zootermopsis nevadensis and Cubitermes severus and in three other arthropods. J Insect Physiol 30:169174. doi: 10.1016/0022-1910(84)90122-7

Blancard D (2012) Tomato diseases: Identification, biology and control: A colour handbook, Second Edition, QUAE. CRC Press

Bloem E, Haneklaus S, Schnug E (2005) Significance of sulfur compounds in the protection of plants against pests and diseases. J Plant Nutr 28:763-784. doi: 10.1081/PLN-200055532

Blokhina OB, Virolainen E, Fagerstedt K V., et al (2000) Antioxidant status of anoxia-tolerant and -intolerant plant species under anoxia and reaeration. Physiol Plant 109:396-403. doi: 10.1034/j.13993054.2000.100405.x

Bolwell GP, Bindschedler L V., Blee KA, et al (2002) The apoplastic oxidative burst in response to biotic stress in plants: A three-component system. J Exp Bot 53:1367-1376. doi: 10.1093/jxb/53.372.1367

Bolwell PP, Page A, Piślewska M, Wojtaszek P (2001) Pathogenic infection and the oxidative defenses in plant apoplast. Protoplasma 217:20-32. doi: 10.1007/BF01289409

Borella J, Becker R, Lima MC, et al (2019) Nitrogen source influences the antioxidative system of soybean plants under hypoxia and re-oxygenation. Sci Agric 76:51-62. doi: 10.1590/1678-992x-2017-0195

Bostock RM, Pye MF, Roubtsova T V. (2014) Predisposition in plant disease: Exploiting the nexus in abiotic and biotic stress perception and response. Annu Rev Phytopathol 52:517-549. doi: 10.1146/annurevphyto-081211-172902

Bousset L, Ermel M, Soglonou B, Husson O (2019) Fungal growth is affected by and affects pH and redox potential (Eh) of the growth medium. Fungal Biol 123:117-124. doi: 10.1002/adsc.201

Bové J., Garnier M (2003) Phloem-and xylem-restricted plant pathogenic bacteria. Plant Sci 164:423-438. doi: $10.1016 / \mathrm{s} 0168-9452(03) 00033-5$

Browne G, Ott N, Poret-Peterson A, et al (2018) Efficacy of anaerobic soil disinfestation for control of Prunus replant disease. Plant Dis 102:209-219. doi: 10.1094/PDIS-09-16-1392-RE

Brugidou C, Opalka N, Yeager M, et al (2002) Stability of rice yellow mottle virus and cellular compartmentalization during the infection process in Oryza sativa ( L .). Virology 297:98-108. doi: 10.1006/viro.2002.1398

Brune a, Emerson D, Breznak J a (1995) The termite gut microflora as an oxygen sink: Microelectrode determination of oxygen and $\mathrm{pH}$ gradients in guts of lower and higher termites. Appl Environ Microbiol 61:2681-7

Bueno E, Mesa S, Bedmar EJ, et al (2012) Bacterial adaptation of respiration from oxic to microoxic and anoxic conditions: Redox control. Antioxid Redox Signal 16:819-852. doi: 10.1089/ars.2011.4051

Bünemann EK, Bongiorno G, Bai Z, et al (2018) Soil quality - A critical review. Soil Biol Biochem 120:105- 
125. doi: 10.1016/j.soilbio.2018.01.030

1621

1622

1623

1624

1625

1626

1627

1628

1629

1630

1631

1632

1633

1634

1635

1636

1637

1638

1639

1640

1641

1642

1643

1644

1645

1646

1647

1648

1649

1650

1651

1652

1653

1654

1655

1656

1657

1658

1659

Burgin AJ, Yang WH, Hamilton SK, Silver WL (2011) Beyond carbon and nitrogen: How the microbial energy economy couples elemental cycles in diverse ecosystems. Front Ecol Environ 9:44-52. doi: $10.1890 / 090227$

Burns NC (1971) Soil pH effects on nematode populations associated with soybeans. J Nematol 3:238-245

Bush DR (1992) The proton-sucrose symport. Photosynth Res 32:155-165

Cakmak I, Marschner H (1988) Increase in membrane permeability and exudation in roots of Zinc deficient plants. J Plant Physiol 132:356-361. doi: 10.1016/S0176-1617(88)80120-2

Calonnec A, Jolivet J, Vivin P, Schnee S (2018) Pathogenicity traits correlate with the susceptible Vitis vinifera leaf physiology transition in the biotroph fungus Erysiphe necator: An adaptation to plant ontogenic resistance. Front Plant Sci 871:1-17. doi: 10.3389/fpls.2018.01808

Campos WG, Schoereder JH, Picanço MC (2003) Performance of an oligophagous insect in relation to the age of the host plant. Neotrop Entomol 32:671-676. doi: 10.1590/s1519-566x2003000400019

Cardinale BJ (2011) Biodiversity improves water quality through niche partitioning. Nature 472:86-91. doi: 10.1038/nature09904

Cardoso EJBN, Vasconcellos RLF, Bini D, et al (2013) Soil health: Looking for suitable indicators. What should be considered to assess the effects of use and management on soil health? Sci Agric 70:274-289. doi: 10.1590/S0103-90162013000400009

Cardoza RE, Mora ME, Hermosa R, et al (2010) TvDim1 of Trichoderma virens is involved in redox-processes and confers resistance to oxidative stresses. Curr Genet 56:63-73. doi: 10.1007/s00294-009-0280-8

Carvalhais LC, Dennis PG, Fedoseyenko D, et al (2011) Root exudation of sugars, amino acids, and organic acids by maize as affected by nitrogen, phosphorus, potassium, and iron deficiency. J Plant Nutr Soil Sci 174:3-11. doi: 10.1002/jpln.201000085

Carvalho LC, Vidigal P, Amâncio S (2015) Oxidative stress homeostasis in grapevine (Vitis vinifera L.). Front Environ Sci 3:1-15. doi: 10.3389/fenvs.2015.00020

Cazemier AE, Den Camp HJMO, Hackstein JHP, Vogels GD (1997) Fibre digestion in arthropods. Comp Biochem Physiol - A Physiol 118:101-109. doi: 10.1016/S0300-9629(96)00443-4

Cazemier AE, Verdoes JC, Reubsaet FAG, et al (2003) Promicromonospora pachnodae sp. nov., a member of the (hemi)cellulolytic hindgut flora of larvae of the scarab beetle Pachnoda marginata. Antonie van Leeuwenhoek, Int J Gen Mol Microbiol 83:135-148. doi: 10.1023/A:1023325817663

Cha JY, Han S, Hong HJ, et al (2016) Microbial and biochemical basis of a Fusarium wilt-suppressive soil. ISME J 10:119-129. doi: 10.1038/ismej.2015.95

Chandrashekara C, Kumar R, Bhatt JC, et al (2012) Suppressive soils in plant disease management. In: Singh VK, Singh Y, Singh A (eds) Eco-friendly innovative approaches in plant disease management. pp 241-256

Chapelle E, Mendes R, Bakker PAH, Raaijmakers JM (2016) Fungal invasion of the rhizosphere microbiome. ISME J 10:265-268. doi: 10.1038/ismej.2015.82

Charrier M, Brune A (2003) The gut microenvironment of helicid snails (Gastropoda: Pulmonata): In-situ profiles of $\mathrm{pH}$, oxygen, and hydrogen determined by microsensors. Can J Zool 81:928-935. doi: 10.1139/z03-071

Chen J, Hanke A, Tegetmeyer HE, et al (2017a) Impacts of chemical gradients on microbial community structur. 
ISME J 11:920-931. doi: 10.1038/ismej.2016.175

1661

1662

1663

1664

1665

1666

1667

1668

1669

1670

1671

1672

1673

1674

1675

1676

1677

1678

1679

1680

1681

1682

1683

1684

1685

1686

1687

1688

1689

1690

1691

1692

1693

1694

1695

1696

1697

1698

1699

Chen R, Song S, Li X, et al (2013) Phosphorus deficiency restricts plant growth but induces pigment formation in the flower stalk of Chinese kale. Hortic Environ Biotechnol 54:243-248. doi: 10.1007/s13580-0130018-X

Chen X, Mao A, Zhang Y, et al (2017b) Carbon and nitrogen forms in soil organic matter influenced by incorporated wheat and corn residues. Soil Sci Plant Nutr 63:377-387. doi: 10.1080/00380768.2017.1359797

Chen Z, Gallie DR (2004) The ascorbic acid redox state controls guard cell signaling and stomatal movement. Plant Cell 16:1143-1162. doi: 10.1105/tpc.021584

Cheng F, Cheng Z (2015) Research progress on the use of plant allelopathy in agriculture and the physiological and ecological mechanisms of allelopathy. Front Plant Sci 6:1-16. doi: 10.3389/fpls.2015.01020

Clarke D, Whitney H, Sutton G, Robert D (2013) Detection and learning of floral electric fields by bumblebees. Science 340:66-9. doi: 10.1126/science.1230883

Clemente-Moreno MJ, Díaz-Vivancos P, Rubio M, et al (2013) Chloroplast protection in plum pox virusinfected peach plants by L-2-oxo-4-thiazolidine-carboxylic acid treatments: Effect in the proteome. Plant, Cell Environ 36:640-654. doi: 10.1111/pce.12003

Clocchiatti A, Hannula SE, van den Berg M, et al (2020) The hidden potential of saprotrophic fungi in arable soil: Patterns of short-term stimulation by organic amendments. Appl Soil Ecol 147:103434. doi: 10.1016/j.apsoil.2019.103434

Conrad R (1996) Soil microorganisms as controllers of atmospheric trace gases (H2, CO, CH4, OCS, N2O, and NO). Microbiol Rev 60:609-640. doi: 10.1007/978-3-642-61096-7_11

Cook JR, Baker KF (1983) The nature and practice of biological control of plant pathogens, American P. St Paul, Minnesota, USA

Cook RJ (2014) Plant health management: Pathogen suppressive soils. In: Van Alfen NKBT-E of A and FS (ed). Academic Press, Oxford, pp 441-455

Cornelissen JHC, Sibma F, Van Logtestijn RSP, et al (2011) Leaf pH as a plant trait: species-driven rather than soil-driven variation. Funct Ecol 25:449-455. doi: 10.1111/j.1365-2435.2010.01765.x

Coskun D, Deshmukh R, Sonah H, et al (2019) The controversies of silicon's role in plant biology. New Phytol 221:67-85. doi: 10.1111/nph.15343

Cottes J (2019) Le couple Eh/pH du sol : Sa mesure, son impact sur la mobilité des nutriments et la croissance du tournesol. Ph.D Thesis, Université de Toulouse, France

Cruz-Munoz M, Munoz-Beristain A, Petrone JR, et al (2019) Growth parameters of Liberibacter crescens suggest ammonium and phosphate as essential molecules in the Liberibacter-plant host interface. BMC Microbiol 19:1-16. doi: 10.1186/s12866-019-1599-Z

Cuypers A, Vangronsveld J, Clijsters H (2001) The redox status of plant cells (AsA and GSH) is sensitive to zinc imposed oxidative stress in roots and primary leaves of Phaseolus vulgaris. Plant Physiol Biochem 39:657-664. doi: 10.1016/S0981-9428(01)01276-1

Das P, Nutan KK, Singla-Pareek SL, Pareek A (2015) Oxidative environment and redox homeostasis in plants: dissecting out significant contribution of major cellular organelles. Front Environ Sci 2:1-11. doi: 10.3389/fenvs.2014.00070 
Datnoff LE, Elmer WH, Huber DM (2007) Mineral nutrition and plant disease. APS Press, St Paul, Minnesota,

1701 USA

Davet P (2004) Microbial ecology of the soil and plant growth. Science Publishers. Inc., Enfield, New Hampshire

Dawood M, Cao F, Jahangir MM, et al (2012) Alleviation of aluminum toxicity by hydrogen sulfide is related to elevated ATPase, and suppressed aluminum uptake and oxidative stress in barley. J Hazard Mater 209210:121-128. doi: 10.1016/j.jhazmat.2011.12.076

De Corato U (2021) Soil microbiome manipulation gives new insights in plant disease-suppressive soils from the perspective of a circular economy: A critical review. Sustain 13:1-41. doi: 10.3390/su13010010

De Deyn GB (2017) Plant life history and above-belowground interactions: missing links. Oikos 126:497-507. doi: 10.1111/oik.03967

De Deyn GB, Cornelissen JHC, Bardgett RD (2008) Plant functional traits and soil carbon sequestration in contrasting biomes. Ecol Lett 11:516-531. doi: 10.1111/j.1461-0248.2008.01164.x

DeAngelis KM, Silver WL, Thompson AW, Firestone MK (2010) Microbial communities acclimate to recurring changes in soil redox potential status. Environ Microbiol 12:3137-3149. doi: 10.1111/j.14622920.2010.02286.x

Debona D, Rodrigues FÁ, Rios JA, Nascimento KJT (2012) Biochemical changes in the leaves of wheat plants infected by Pyricularia oryzae. Phytopathology 102:1121-9. doi: 10.1094/PHYTO-06-12-0125-R

Deguine J-P, Gloanec C, Laurent P, et al (2017) Agroecological Crop Protection. Springer Netherlands, Dordrecht

Di Gioia F, Ozores-Hampton M, Hong J, et al (2016) The effects of anaerobic soil disinfestation on weed and nematode control, fruit yield, and quality of florida fresh-market tomato. HortScience 51:703-711. doi: 10.21273/hortsci.51.6.703

Diéguez-Uribeondo J, Förster H, Adaskaveg JE (2008) Visualization of localized pathogen-induced pH modulation in almond tissues infected by Colletotrichum acutatum using confocal scanning laser microscopy. Phytopathology 98:1171-1178. doi: 10.1094/PHYTO-98-11-1171

Dietz K-J (2003) Redox control, redox signaling, and redox homeostasis in plant cells. Int Rev Cytol 228:141193. doi: 10.1016/S0074-7696(03)28004-9

Dietz K-J, Turkan I, Krieger-Liszkay A (2016) Redox- and reactive oxygen species-dependent signalling in and from the photosynthesizing chloroplast. Plant Physiol 171:pp.00375.2016. doi: 10.1104/pp.16.00375

Dini-Andreote F, Elsas JD (2013) Back to the basics: The need for ecophysiological insights to enhance our understanding of microbial behaviour in the rhizosphere. Plant Soil 373:1-15. doi: 10.1007/s11104-013$1687-\mathrm{z}$

Dini-Andreote F, Stegen JC, Van Elsas JD, Salles JF (2015) Disentangling mechanisms that mediate the balance between stochastic and deterministic processes in microbial succession. Proc Natl Acad Sci U S A 112:E1326-E1332. doi: 10.1073/pnas.1414261112

Dodd IC, Tan LP, He J (2003) Do increases in xylem sap pH and/or ABA concentration mediate stomatal closure following nitrate deprivation? J Exp Bot 54:1281-1288. doi: 10.1093/jxb/erg122

Dordas C (2008) Role of nutrients in controlling plant diseases in sustainable agriculture. A review. Agron Sustain Dev 28:33-46. doi: 10.1051/agro:2007051 
Downum KR, Rodriguez E (1986) Toxicological action and ecological importance of plant photosensitizers. J Chem Ecol 12:823-834. doi: 10.1007/BF01020254

Dragičević V (2015) Thermodynamics of abiotic stress and stress tolerance of cultivated plants. Recent Adv Thermo Fluid Dyn 195-221. doi: 10.5772/60990

Dubreuil G, Deleury E, Magliano M, et al (2011) Peroxiredoxins from the plant parasitic root-knot nematode, Meloidogyne incognita, are required for successful development within the host. Int J Parasitol 41:385396. doi: 10.1016/j.ijpara.2010.10.008

Duru M, Therond O, Fares M (2015) Designing agroecological transitions; A review. Agron Sustain Dev 35:1237-1257. doi: 10.1007/s13593-015-0318-x

Ebert A, Brune A (1997) Hydrogen concentration profiles at the oxic-anoxic interface: A microsensor study of the hindgut of the wood-feeding lower termite Reticulitermes flavipes (Kollar). Appl Environ Microbiol 63:4039-4046. doi: 10.1128/aem.63.10.4039-4046.1997

1752

Egert M, Stingl U, Bruun LD, et al (2005) Structure and topology of microbial communities in the major gut compartments of Melolontha melolontha larvae (Coleoptera: Scarabaeidae). Appl Environ Microbiol 71:4556-4566. doi: 10.1128/AEM.71.8.4556

Ellakwa ET (2014) Effect of host plant on gut physicochemistry and digestive enzymes of the cutworn (Agrotis ipsilon) larvae. Am J drug Discov Dev 4:248-252

Elmer WH, Datnoff LE (2014) Mineral nutrition and suppression of plant disease. Encycl Agric Food Syst 4:231-244. doi: http://dx.doi.org/10.1016/B978-0-444-52512-3.00251-5

Elstner EF, Osswald W (1994) Mechanisms of oxygen activation during plant stress. Proc R Soc Edinburgh Sect B Biol Sci 102:131-154. doi: 10.1017/s0269727000014068

Endo RM, Linn MB (1960) The white-rust disease of Horseradish. Bull. Illinois Agric. Exp. Stn. 56 pp.

Epstein E (1994) The anomaly of silicon in plant biology. Proc Natl Acad Sci USA 91:11-17

Eutick ML, O’Brien RW, Slaytor M (1976) Aerobic state of gut of Nasutitermes exitiosus and Coptotermes lacteus, high and low caste termites. J Insect Physiol 22:1377-1380. doi: 10.1016/0022-1910(76)90161-X

Exposito-Rodriguez M, Laissue PP, Yvon-Durocher G, et al (2017) Photosynthesis-dependent $\mathrm{H}_{2} \mathrm{O}_{2}$ transfer from chloroplasts to nuclei provides a high-light signalling mechanism. Nat Commun 8:1-10. doi: 10.1038/s41467-017-00074-w

Farber DH, Mundt CC (2017) Effect of plant age and leaf position on susceptibility to wheat stripe rust. Phytopathology 107:412-417. doi: 10.1094/phyto-07-16-0284-r

Farkas GL, Király Z, Solymosy F (1960) Role of oxidative metabolism in the localization of plant viruses. Virology 12:408-421. doi: 10.1016/0042-6822(60)90163-X

Fatima U, Senthil-Kumar M (2015) Plant and pathogen nutrient acquisition strategies. Front Plant Sci 6:1-12. doi: $10.3389 /$ fpls.2015.00750

Fauteux F, Rémus-Borel W, Menzies JG, Bélanger RR (2005) Silicon and plant disease resistance against pathogenic fungi. FEMS Microbiol Lett 249:1-6. doi: 10.1016/j.femsle.2005.06.034

Felle HH (2005) pH regulation in anoxic plants. Ann Bot 96:519-532. doi: 10.1093/aob/mci207

Felle HH (2001) pH: Signal and messenger in plant cells. Plant Biol 3:577-591. doi: 10.1055/s-2001-19372

Felle HH (2006) Apoplastic pH during low-oxygen stress in barley. Ann Bot 98:1085-1093. doi: 10.1093/aob/mcl193 
Felle HH, Herrmann A, Hanstein S, et al (2004) Apoplastic pH signaling in barley leaves attacked by the powdery mildew fungus Blumeria graminis f. sp. hordei. Mol Plant-Microbe Interact 17:118-123. doi: 10.1094/MPMI.2004.17.1.118

Fernandes TR, Segorbe D, Prusky D, Di Pietro A (2017) How alkalinization drives fungal pathogenicity. PLoS Pathog 13:1-8. doi: 10.1371/journal.ppat.1006621

Ferreira M, Domingos M (2012) Seasonal characterization of antioxidant responses in plants of Ipomoea nil cv. Scarlet O’Hara. Brazilian J Biol 72:831-837. doi: 10.1590/s1519-69842012000500008

Fiedler S, Scholich GU, Kleber M (2003) Construction and evaluation of redox electrode with summing operational amplifier: Application in study of methane emission. Commun Soil Sci Plant Anal 34:481496. doi: 10.1081/CSS-120017833

Fischer WR, Flessa H, Schaller G (1989) pH values and redox potentials in microsites of the rhizosphere. Zeitschrift für Pflanzenernährung und Bodenkd 152:191-195. doi: 10.1002/jpln.19891520209

Fobert PR, Després C (2005) Redox control of systemic acquired resistance. Curr Opin Plant Biol 8:378-82. doi: 10.1016/j.pbi.2005.05.003

Footitt S, Cohn MA (1992) Seed dormancy in red rice. Plant Physiol 100:1196-1202. doi: 10.1104/pp.80.2.531

Foyer CH (2005) Redox homeostasis and antioxidant signaling: A metabolic interface between stress perception and physiological responses. Plant Cell Online 17:1866-1875. doi: 10.1105/tpc.105.033589

Foyer CH, Noctor G (2016) Stress-triggered redox signalling: What's in pROSpect? Plant, Cell Environ 39:951964. doi: 10.1111/pce.12621

Foyer CH, Noctor G (2013) Redox signaling in plants. Antioxid Redox Signal 18:2087-2090. doi: 10.1089/ars.2013.5278

Foyer CH, Shigeoka S (2011) Understanding oxidative stress and antioxidant functions to enhance photosynthesis. Plant Physiol 155:93-100. doi: 10.1104/pp.110.166181

Frederickson Matika DE, Loake GJ (2013) Redox regulation in plant immune function. Antioxid Redox Signal 21:1373-1388. doi: 10.1089/ars.2013.5679

Fromm J, Bauer T (1994) Action potentials in maize sieve tubes change phloem translocation. J Exp Bot 45:463-469. doi: 10.1093/jxb/45.4.463

Fukuta Y, Suzuki T, Yanagihara S, et al (2019) Genetic variation of blast (Pyricularia oryzae cavara) resistance in rice (Oryza sativa 1.) accessions widely used in kenya. Breed Sci 69:672-679. doi: 10.1270/jsbbs.19065

Fürstenberg-Hägg J, Zagrobelny M, Bak S (2013) Plant defense against insect herbivores. Int J Mol Sci 14:10242-10297. doi: 10.3390/ijms140510242

García G, Clemente-Moreno MJ, Díaz-Vivancos P, et al (2020) The apoplastic and symplastic antioxidant system in onion: Response to long-term salt stress. Antioxidants 9:67. doi: 10.3390/antiox9010067

Garnier M, Foissac X, Gaurivaud P, et al (2001) Mycoplasmas plants insect vectors: A matrimonial triangle. Comptes Rendus l'Academie des Sci - Ser III 324:923-928. doi: 10.1016/S0764-4469(01)01372-5

Gaupels F, Durner J, Kogel KH (2017) Production, amplification and systemic propagation of redox messengers in plants? The phloem can do it all! New Phytol 214:554-560. doi: 10.1111/nph.14399

Gebrie SA (2016) Biotrophic fungi infection and plant defense mechanism. J Plant Pathol Microbiol 7:. doi: $10.4172 / 2157-7471.1000378$

Geigenberger P (2003) Response of plant metabolism to too little oxygen. Curr Opin Plant Biol 6:247-256. doi: 
Geilfus CM (2017) The pH of the Apoplast: Dynamic Factor with Functional Impact Under Stress. Mol Plant 10:1371-1386. doi: 10.1016/j.molp.2017.09.018

1823

1824

1825

1826

1827

1828

1829

1830

1831

1832

1833

1834

1835

1836

1837

1838

1839

1840

1841

1842

1843

1844

1845

1846

1847

1848

1849

1850

1851

1852

1853

1854

1855

1856

1857

1858

1859

Geilfus CM, Mühling KH (2011) Real-time imaging of leaf apoplastic pH dynamics in response to $\mathrm{NaCl}$ stress. Front Plant Sci 2:1-11. doi: 10.3389/fpls.2011.00013

Geilfus CM, Wang L, Wu J, Xue C (2020) The pH of the leaf apoplast is critical for the formation of Pseudomonas syringae-induced lesions on leaves of the common bean (Phaseolus vulgaris). Plant Sci 290:110328. doi: 10.1016/j.plantsci.2019.110328

Geiser E, Wiebach V, Wierckx N, Blank LM (2014) Prospecting the biodiversity of the fungal family Ustilaginaceae for the production of value-added chemicals. Fungal Biol Biotechnol 1:1-10. doi: 10.1186/s40694-014-0002-y

Gerendás J, Schurr U (1999) Physicochemical aspects of ion relations and pH regulation in plants - A quantitative approach. J Exp Bot 50:1101-1114. doi: 10.1093/jxb/50.336.1101

Gerwien F, Skrahina V, Kasper L, et al (2018) Metals in fungal virulence. FEMS Microbiol Rev 42:1-21. doi: 10.1093/femsre/fux050

Gianfreda L (2015) Enzymes of importance to rhizosphere processes. J Soil Sci Plant Nutr 15:283-306. doi: $10.4067 / \mathrm{s} 0718-95162015005000022$

Giaquinta R (1977) Phloem loading of sucrose: pH dependence and selectivity. Plant Physiol 59:750-755. doi: 10.1104/pp.59.4.750

Gillet FX, Cattoni DI, Petiot-Bécard S, et al (2013) The RYMV-encoded viral suppressor of RNA silencing P1 is a zinc-binding protein with redox-dependent flexibility. J Mol Biol 425:2423-2435. doi: 10.1016/j.jmb.2013.03.028

Giordano M (2013) Homeostasis: an underestimated focal point of ecology and evolution. Plant Sci 211:92-101. doi: 10.1016/j.plantsci.2013.07.008

Gjetting KSK, Ytting CK, Schulz A, Fuglsang AT (2012) Live imaging of intra-and extracellular pH in plants using pHusion, a novel genetically encoded biosensor. J Exp Bot 63:3207-3218. doi: 10.1093/jxb/ers040

Gloser V, Korovetska H, Martín-Vertedor AI, et al (2016) The dynamics of xylem sap pH under drought: a universal response in herbs? Plant Soil 409:259-272. doi: 10.1007/s11104-016-2962-6

Gnanamanickam SS (2006) Plant-associated bacteria. Springer, Dordrecht, The Netherlands

Goggin FL, Avila C a., Lorence A (2010) Vitamin C content in plants is modified by insects and influences susceptibility to herbivory. BioEssays 32:777-790. doi: 10.1002/bies.200900187

González-Bosch C (2018) Priming plant resistance by activation of redox-sensitive genes. Free Radic Biol Med 122:171-180. doi: 10.1016/j.freeradbiomed.2017.12.028

Goodman RN, Kiraly Z, Zaitlin M (1967) The biochemstry and physiology of infectious plant disease. Van Nostrand Company, Toronto

Gour HN, Ashiya J, Mali BL, Nath R (2000) Influence of temperature and pH on the growth and toxin production by Xanthomonas axonopodis pv. vignicola inciting leaf blight of cowpea. J Mycol Plant Pathol 30:389-392

Grams TEE, Lautner S, Felle HH, et al (2009) Heat-induced electrical signals affect cytoplasmic and apoplastic $\mathrm{pH}$ as well as photosynthesis during propagation through the maize leaf. Plant, Cell Environ 32:319-326. 
doi: 10.1111/j.1365-3040.2008.01922.x

1861

1862

1863

1864

1865

1866

1867

1868

1869

1870

1871

1872

1873

1874

1875

1876

1877

1878

1879

1880

1881

1882

1883

1884

1885

1886

1887

1888

1889

1890

1891

1892

1893

1894

1895

1896

1897

1898

1899

Greggers U, Koch G, Schmidt V, et al (2013) Reception and learning of electric fields in bees. Proc R Soc B Biol Sci 280:. doi: 10.1098/rspb.2013.0528

Grignon C, Sentenac H (1991) pH and ionic conditions in the apoplast. Annu Rev Plant Physiol Plant Mol Biol 42:103-128. doi: 10.1146/annurev.pp.42.060191.000535

Gupta N, Debnath S, Sharma S, et al (2017) Role of nutrients in controlling the plant diseases in sustainable agriculture. In: Meena V et al. (ed) Agriculturally Important Microbes for Sustainable Agriculture. Springer Nature, Singapore, pp 217-262

Gupta R, Lee SE, Agrawal GK, et al (2015) Understanding the plant-pathogen interactions in the context of proteomics-generated apoplastic proteins inventory. Front Plant Sci 6:1-7. doi: 10.3389/fpls.2015.00352

Guyonnet JP, Cantarel AAM, Simon L, Haichar FZ (2018a) Root exudation rate as functional trait involved in plant nutrient-use strategy classification. Int J Bus Innov Res 17:8573-8581. doi: 10.1002/ece3.4383

Guyonnet JP, Guillemet M, Dubost A, et al (2018b) Plant nutrient resource use strategies shape active rhizosphere microbiota through root exudation. Front Plant Sci 871:1-13. doi: 10.3389/fpls.2018.01662

Haapalainen M (2014) Biology and epidemics of Candidatus Liberibacter species, psyllid-transmitted plantpathogenic bacteria. Ann Appl Biol 165:172-198. doi: 10.1111/aab.12149

Haas C, Horn R (2018) Impact of small-scaled differences in micro-aggregation on physico-chemical parameters of macroscopic biopore walls. Front Environ Sci 6:1-12. doi: 10.3389/fenvs.2018.00090

Hafke JB, Van Amerongen JK, Kelling F, et al (2005) Thermodynamic battle for photosynthate acquisition between sieve tubes and adjoining parenchyma in transport phloem. Plant Physiol 138:1527-1537. doi: 10.1104/pp.104.058511

Halliwell B, Gutteridge JMC (1984) Oxygen toxicity, oxygen radicals, transition metals and disease. Biochem J 219:1-14. doi: 10.1042/bj2190001

Handy D, Loscalzo J (2012) Redox regulation of mitochondrial function. Antioxid Redox Signal 16:1323-1368

Harrison JF (2001) Insect acid-base physiology. Annu Rev Entomol 46:221-250. doi: 10.1146/annurev.ento.46.1.221

Hasanuzzaman M, Bhuyan MHMB, Nahar K, et al (2018) Potassium: A vital regulator of plant responses and tolerance to abiotic stresses. Agronomy 8:. doi: 10.3390/agronomy8030031

Hemantaranjan A, Bhanu AN, Singh M, et al (2014) Heat stress responses and thermotolerance. Adv Plants Agric Res 1:62-70. doi: 10.15406/apar.2014.01.00012

Hernández I, Munné-Bosch S (2015) Linking phosphorus availability with photo-oxidative stress in plants. J Exp Bot 66:2889-2900. doi: 10.1093/jxb/erv056

Hernández JA, Gullner G, Clemente-Moreno MJ, et al (2016) Oxidative stress and antioxidative responses in plant-virus interactions. Physiol Mol Plant Pathol 94:134-148. doi: 10.1016/j.pmpp.2015.09.001

Hess DT, Matsumoto A, Kim S-O, et al (2005) Protein S-nitrosylation: purview and parameters. Nat Rev Mol Cell Biol 6:150-166. doi: 10.1038/nrm1569

Hijaz F, Killiny N (2014) Collection and chemical composition of phloem sap from Citrus sinensis L. Osbeck (sweet orange). PLoS One 9:1-11. doi: 10.1371/journal.pone.0101830

Hinsinger P, Plassard C, Tang C, et al (2003) Origins of root-mediated pH changes in the rhizosphere and their responses to environmental constraints: A review. Plant Soil 248:43-59 
Hipper C, Brault V, Ziegler-Graff V, Revers F (2013) Viral and cellular factors involved in phloem transport of plant viruses. Front Plant Sci 4:1-24. doi: 10.3389/fpls.2013.00154

Hogenhout SA, Loria R (2008) Virulence mechanisms of Gram-positive plant pathogenic bacteria. Curr Opin Plant Biol 11:449-456. doi: 10.1016/j.pbi.2008.05.007

Howlett BJ, Idnurm A, Pedras MSC (2001) Leptosphaeria maculans, the causal agent of blackleg disease of Brassicas. Fungal Genet Biol 33:1-14. doi: 10.1006/fgbi.2001.1274

Hua C, Li C, Jiang Y, et al (2020) Response of soybean cyst nematode (Heterodera glycines) and root-knot nematodes (Meloidogyne spp.) to gradients of $\mathrm{pH}$ and inorganic salts. Plant Soil 305-318. doi: 10.1007/s11104-020-04677-z

Hua J (2013) Modulation of plant immunity by light, circadian rhythm, and temperature. Curr Opin Plant Biol 16:406-413. doi: 10.1016/j.pbi.2013.06.017

Huber D, Römheld V, Weinmann M (2011) Relationship between nutrition, plant diseases and pests. In: Marschner's Mineral Nutrition of Higher Plants: Third Edition. pp 283-298

Huber DM, Haneklaus S (2007) Managing nutrition to control plant disease. Landbauforsch Völkenrode 4 57:313-322. doi: 10.1016/B978-0-12-803581-8.02518-2

Huber DM, Thompson IA (2007) Nitrogen and plant disease. In: Datnoff LE, Elmer WE, Huber DM (eds) Mineral nutrition and plant disease, APS Press. The American phytopathological society, St Paul, Minnesota, USA, pp 31-44

Huber DM, Watson RD (1974) Nitrogen form and plant disease. Annu Rev Phytopathol 12:139-165. doi: 10.1146/annurev.py.12.090174.001035

Huot B, Yao J, Montgomery BL, He SY (2014) Growth-defense tradeoffs in plants: A balancing act to optimize fitness. Mol Plant 7:1267-1287. doi: 10.1093/mp/ssu049

Husson O (2013) Redox potential (Eh) and pH as drivers of soil/plant/microorganism systems: a transdisciplinary overview pointing to integrative opportunities for agronomy. Plant Soil 362:389-417. doi: 10.1007/s11104-012-1429-7

Husson O, Audebert A, Benada J, et al (2018a) Leaf Eh and pH : A novel indicator of plant stress . Spatial, temporal and genotypic variability in rice. Agronomy 8:1-24. doi: 10.3390/agronomy8100209

Husson O, Brunet A, Babre D, et al (2018b) Conservation Agriculture systems alter the electrical characteristics (Eh, pH and EC) of four soil types in France. Soil Tillage Res 176:57-68. doi: 10.1016/j.still.2017.11.005

Husson O, Husson B, Brunet A, et al (2016) Practical improvements in soil redox potential ( Eh ) measurement for characterisation of soil properties . Application for comparison of conventional and conservation agriculture cropping systems. Anal Chim Acta 906:98-109. doi: 10.1016/j.aca.2015.11.052

Hwang H-H, Yu M, Lai E-M (2017) Agrobacterium -mediated plant transformation: Biology and applications. Arab B 15:e0186. doi: 10.1199/tab.0186

Igamberdiev AU, Baron K, Manac'h-Little N, et al (2005) The haemoglobin/nitric oxide cycle: Involvement in flooding stress and effects on hormone signalling. Ann Bot 96:557-564. doi: 10.1093/aob/mci210

Igamberdiev AU, Bykova N V. (2018) Role of organic acids in the integration of cellular redox metabolism and mediation of redox signalling in photosynthetic tissues of higher plants. Free Radic Biol Med 122:74-85. doi: 10.1016/j.freeradbiomed.2018.01.016

Ilan T, Kim-Shapiro DB, Bock CH, Shapiro-Ilan DI (2013) Magnetic and electric fields induce directional 
Jackson MB, Saker LR, Crisp CM, et al (2003) Ionic and pH signalling from roots to shoots of flooded tomato plants in relation to stomatal closure. Plant Soil 253:103-113. doi: 10.1023/A:1024588532535

1943

1944

1945

1946

1947

1948

1949

1950

1951

1952

1953

1954

1955

1956

1957

1958

1959

1960

1961

1962

1963

1964

1965

1966

1967

1968

1969

1970

1971

1972

1973

1974

1975

1976

1977

1978

1979

Jacoby R, Peukert M, Succurro A, et al (2017) The role of soil microorganisms in plant mineral nutritioncurrent knowledge and future directions. Front Plant Sci 8:1-19. doi: 10.3389/fpls.2017.01617

Janku M, Luhová L, Petrivalský M (2019) On the origin and fate of reactive oxygen species in plant cell compartments. Antioxidants 8:105

Jashvantlal PS (2008) Management of bacterial blight of rice. PhD thesis Navsari Agricultural university, India

Jha G, Sonti R V (2009) Attack and defense in Xanthomonas-rice interactions. Proc Indian Natn Sci Acad 75:49-68

Jiang Y (1996) Oxidative interactions between the spotted alfalfa aphid (Therioaphis trifolii maculata) (Homoptera: Aphididae) and the host plant Medicago sativa. Bull Entomol Res 86:533-540. doi: $10.1017 / \mathrm{S} 0007485300039328$

Jiang Y, Miles PW (1993) Responses of a compatible lucerne variety to attack by spotted alfalfa aphid: changes in the redox balance in affected tissues. Entomol Exp Appl 67:263-274. doi: 10.1111/j.15707458.1993.tb01677.x

Johannes A, Matter A, Schulin R, et al (2017) Optimal organic carbon values for soil structure quality of arable soils. Does clay content matter? Geoderma 302:14-21. doi: 10.1016/j.geoderma.2017.04.021

Johnson GN (2003) Thiol regulation of the thylakoid electron transport chain - A missing link in the regulation of photosynthesis? Biochemistry 42:3040-3044. doi: 10.1021/bi027011k

Johnson KS, Felton GW (1996a) Physiological and dietary influences on midgut redox conditions in generalist lepidopteran larvae. J Insect Physiol 42:191-198. doi: 10.1016/0022-1910(95)00096-8

Johnson KS, Felton GW (1996b) Potential Influence of midgut pH and redox potential on protein utilization in insect herbivores. Arch Insect Biochem Physiol 32:85-105

Jones DL, Hodge A, Kuzyakov Y (2004) Plant and mycorrhizal regulation of rhizodeposition. New Phytol 163:459-480. doi: 10.1111/j.1469-8137.2004.01130.x

Jones DS, Kohl C, Grettenberger C, et al (2015) Geochemical niches of Iron-oxidizing acidophiles in acidic coal mine drainage. Appl Environ Microbiol 81:1242-1250. doi: 10.1128/AEM.02919-14

Jonkers W, Estrada AER, Lee K, et al (2012) Metabolome and transcriptome of the interaction between Ustilago maydis and Fusarium verticillioides in vitro. Appl Environ Microbiol 78:3656-3667. doi:

10.1128/AEM.07841-11

Joseph A, Olufolaji D, Nwilene F, et al (2011) Effect of leaf age on rice yeallow mottle virus severity and chlorophyll content with echanical inoculation and vector transmission method. Trends Appl Sci Res 6:691-698. doi: 10.3923/tasr.2011.1345.1351

Jozefczak M, Bohler S, Schat H, et al (2015) Both the concentration and redox state of glutathione and ascorbate influence the sensitivity of arabidopsis to cadmium. Ann Bot 116:601-612. doi: 10.1093/aob/mcv075

Jubany-Mari T, Alegre-Batlle L, Jiang K, Feldman LJ (2010) Use of a redox-sensing GFP (c-roGFP1) for realtime monitoring of cytosol redox status in Arabidopsis thaliana water-stressed plants. FEBS Lett 584:88997. doi: 10.1016/j.febslet.2010.01.014

Juttukonda LJ, Skaar EP (2015) Manganese homeostasis and utilization in pathogenic bacteria. Mol Microbiol 
97:216-228. doi: 10.1016/j.physbeh.2017.03.040

1981

1982

1983

1984

1985

1986

1987

1988

1989

1990

1991

1992

1993

1994

1995

1996

1997

1998

1999

2000

2001

2002

2003

2004

2005

2006

2007

2008

2009

2010

2011

2012

2013

2014

2015

2016

2017

2018

2019

Kapoor D, Sharma R, Handa N, et al (2015) Redox homeostasis in plants under abiotic stress: role of electron carriers, energy metabolism mediators and proteinaceous thiols. Front Environ Sci 3:1-12. doi: $10.3389 /$ fenvs.2015.00013

Kappler A, Brune A (2002) Dynamics of redox potential and changes in redox state of iron and humic acids during gut passage in soil-feeding termites (Cubitermes spp.). Soil Biol Biochem 34:221-227

Karmous I, Trevisan R, Ferjani E El, et al (2017) Redox biology response in germinating Phaseolus vulgaris seeds exposed to copper : Evidence for differential redox buffering in seedlings and cotyledon. PLoS One $12: 1-23$

Keane P, Kerr A (1997) Factors affecting disease development. In: Brown J, Ogle H (eds) Plant pathogens and plant diseases, APPS. Rockvale pubications, Amidale, NSW, pp 287-298

Kilian J, Peschke F, Berendzen KW, et al (2012) Prerequisites, performance and profits of transcriptional profiling the abiotic stress response. Biochim Biophys Acta - Gene Regul Mech 1819:166-175. doi: 10.1016/j.bbagrm.2011.09.005

Killiny N (2017) Metabolite signature of the phloem sap of fourteen citrus varieties with different degrees of tolerance to Candidatus Liberibacter asiaticus. Physiol Mol Plant Pathol 97:20-29. doi: 10.1016/j.pmpp.2016.11.004

Király L, Hafez YM, Fodor J, Király Z (2008) Suppression of tobacco mosaic virus-induced hypersensitive-type necrotization in tobacco at high temperature is associated with downregulation of NADPH oxidase and superoxide and stimulation of dehydroascorbate reductase. J Gen Virol 89:799-808. doi: 10.1099/vir.0.83328-0

Kissoudis C, van de Wiel C, Visser RGF, van der Linden G (2014) Enhancing crop resilience to combined abiotic and biotic stress through the dissection of physiological and molecular crosstalk. Front Plant Sci 5:1-20. doi: 10.3389/fpls.2014.00207

Knight NL, Sutherland MW (2016) Histopathological assessment of Fusarium pseudograminearum colonization of cereal culms during crown rot infections. Plant Dis 100:252-259. doi: 10.1094/PDIS-04-15-0476-RE

Koch C, Harnisch F (2016) Is there a specific ecological niche for electroactive iicroorganisms? ChemElectroChem 3:1282-1295. doi: 10.1002/celc.201600079

Koch M. ; Mew T. (1991) Effect of plant age and leaf maturity on the quantitative resitance of rice cultivars to Xanthomonas campestris pv. oryzae. Plant Dis September:901-904

Kocsy G, Tari I, Vanková R, et al (2013) Redox control of plant growth and development. Plant Sci 211:77-91. doi: 10.1016/j.plantsci.2013.07.004

Kong P, Moorman GW, Lea-Cox JD, et al (2009) Zoosporic tolerance to pH stress and its implications for Phytophthora species in aquatic ecosystems. Appl Environ Microbiol 75:4307-4314. doi: 10.1128/AEM.00119-09

Köpke B, Wilms R, Engelen B, et al (2005) Microbial diversity in coastal subsurface sediments: A cultivation approach using various electron acceptors and substrate gradients. Appl Environ Microbiol 71:7819-7830. doi: 10.1128/AEM.71.12.7819-7830.2005

Korenblum E, Dong Y, Szymanski J, et al (2020) Rhizosphere microbiome mediates systemic root metabolite exudation by root-to-root signaling. Proc Natl Acad Sci U S A 117:3874-3883. doi: 
Kováčik J, Bačkor M (2007) Changes of phenolic metabolism and oxidative status in nitrogen-deficient Matricaria chamomilla plants. Plant Soil 297:255-265. doi: 10.1007/s11104-007-9346-x

Kranzler C, Rudolf M, Keren N, Schleiff E (2013) Iron in Cyanobacteria. Adv Bot Res 65:57-105. doi: 10.1016/B978-0-12-394313-2.00003-2

Krasil'nikov NA (1958) Soil microorganisms and higher plants. Academy of Sciences of the USSR Institute of Microbiology, Moscow, USSR

Krasnow CS, Hausbeck MK (2017) Influence of pH and etridiazole on pythium species. Horttechnology 27:367374. doi: 10.21273/HORTTECH03633-16

Krebelj AJ, Čepin U, Ravnikar M, Novak MP (2015) Spatio-temporal distribution of Grapevine fanleaf virus (GFLV) in grapevine. Eur J Plant Pathol 142:159-171. doi: 10.1007/s10658-015-0600-4

Krishnan N, Kodrík D (2006) Antioxidant enzymes in Spodoptera littoralis (Boisduval): Are they enhanced to protect gut tissues during oxidative stress? J Insect Physiol 52:11-20. doi: 10.1016/j.jinsphys.2005.08.009

Krishnan N, Kodrík D, Kłudkiewicz B, Sehnal F (2009) Glutathione-ascorbic acid redox cycle and thioredoxin reductase activity in the digestive tract of Leptinotarsa decemlineata (Say). Insect Biochem Mol Biol 39:180-188. doi: 10.1016/j.ibmb.2008.11.001

Krishnan N, Kodrík D, Turanli F, Sehnal F (2007) Stage-specific distribution of oxidative radicals and antioxidant enzymes in the midgut of Leptinotarsa decemlineata. J Insect Physiol 53:67-74. doi: 10.1016/j.jinsphys.2006.10.001

Kruk J, Aboul-Enein HY, Kładna A, Bowser JE (2019) Oxidative stress in biological systems and its relation with pathophysiological functions: the effect of physical activity on cellular redox homeostasis. Free Radic Res 53:497-521. doi: 10.1080/10715762.2019.1612059

Kuzniak E (2010) The ascorbate-gluathione cycle and related redox signals in plant-pathogen interactions. In: Ascorbate-Glutathione Pathway and Stress Tolerance in Plants. Springer, Dordrecht, pp 115-136

Kuzniak E, Skłodowska M, Kużniak E, Skłodowska M (2005) Fungal pathogen-induced changes in the antioxidant systems of leaf peroxisomes from infected tomato plants. Planta 222:192-200. doi: $10.1007 / \mathrm{s} 00425-005-1514-8$

Labudda M, Muszyńska E, Gietler M, et al (2020) Efficient antioxidant defense systems of spring barley in response to stress induced jointly by the cyst nematode parasitism and cadmium exposure. Plant Soil 189206. doi: 10.1007/s11104-020-04713-y

Lacroix C, Seabloom EW, Borer ET (2014) Environmental nutrient supply alters prevalence and weakens competitive interactions among coinfecting viruses. J Physiol 204:424-433. doi: 10.1111/nph.12909

Lamb C, Dixon RA (1997) The oxidative burst in plant disease resistance. Annu Rev Plant Biol 48:251-275

Lambers H, Mougel C, Jaillard B, Hinsinger P (2009) Plant-microbe-soil interactions in the rhizosphere: an evolutionary perspective. Plant Soil 321:83-115. doi: 10.1007/s11104-009-0042-x

Lamichhane JR (2015) Bacterial diseases of crops: Elucidation of the factors that lead to differences between field and experimental infections. Adv Agron 134:227-246. doi: 10.1016/bs.agron.2015.06.006

Lamichhane JR, Venturi V (2015) Synergisms between microbial pathogens in plant disease complexes: A growing trend. Front Plant Sci 6:1-12. doi: 10.3389/fpls.2015.00385

Landraud P, Chuzeville S, Billon-Grande G, et al (2013) Adaptation to $\mathrm{pH}$ and role of PacC in the rice blast 
fungus Magnaporthe oryzae. PLoS One 8:. doi: 10.1371/journal.pone.0069236

2061

2062

2063

2064

2065

2066

2067

2068

2069

2070

2071

2072

2073

2074

2075

2076

2077

2078

2079

2080

2081

2082

2083

2084

2085

2086

2087

2088

2089

2090

2091

2092

2093

2094

2095

2096

2097

2098

2099

Lebreton L, Daval S, Guillerm-Erckelboudt AY, et al (2014) Sensitivity to pH and ability to modify ambient $\mathrm{pH}$ of the take-all fungus Gaeumannomyces graminis var. tritici. Plant Pathol 63:117-128. doi: 10.1111/ppa.12062

Lehmann S, Serrano M, Haridon FL, et al (2015) Reactive oxygen species and plant resistance to fungal pathogens. Phytochemistry 112:54-62. doi: 10.1016/j.phytochem.2014.08.027

Lemke T, Stingl U, Egert M, et al (2003) Physicochemical conditions and microbial activities in the highly alkaline gut of the humus-feeding larva of Pachnoda ephippiata (Coleoptera: Scarabaeidae). Appl Environ Microbiol 69:6650-6658. doi: 10.1128/AEM.69.11.6650-6658.2003

Leveau JH (2019) A brief from the leaf: latest research to inform our understanding of the phyllosphere microbiome. Curr Opin Microbiol 49:41-49. doi: 10.1016/j.mib.2019.10.002

Li C, Lesnik KL, Liu H (2017) Stay connected : Electrical conductivity of microbial aggregates. Biotechnol Adv 35:669-680. doi: 10.1016/j.biotechadv.2017.07.010

Li H, Chen XW, Wu L, et al (2020) Effects of arbuscular mycorrhizal fungi on redox homeostasis of rice under Cd stress. Plant Soil 121-138. doi: 10.1007/s11104-020-04678-y

Li J, Nishimura Y, Zhao X, Fukumoto Y (2014) Effects of drought stress on the metabolic properties of active oxygen species, nitrogen and photosynthesis in cucumber "Jinchun No. 5” seedlings. Japan Agric Res Q 48:175-181. doi: 10.6090/jarq.48.175

Li SX, Wang ZH, Stewart BA (2013) Responses of crop plants to ammonium and nitrate N. Adv Agron 118:205-397. doi: 10.1016/B978-0-12-405942-9.00005-0

Li Y, Yu S, Strong J, Wang H (2012) Are the biogeochemical cycles of carbon, nitrogen, sulfur, and phosphorus driven by the "FeIII-FeII redox wheel" in dynamic redox environments? J Soils Sediments 12:683-693. doi: $10.1007 / \mathrm{s} 11368-012-0507-\mathrm{z}$

Liao Y, Tian M, Zhang H, et al (2015) Salicylic acid binding of mitochondrial alpha-ketoglutarate dehydrogenase E2 affects mitochondrial oxidative phosphorylation and electron transport chain components and plays a role in basal defense against tobacco mosaic virus in tomato. New Phytol 205:1296-1307. doi: 10.1111/nph.13137

Littman DR, Pamer EG (2011) Role of the commensal microbiota in normal and pathogenic host immune responses. Cell Host Microbe 10:311-323. doi: 10.1016/j.chom.2011.10.004

Liu G, Greenshields DL, Sammynaiken R, et al (2007) Targeted alterations in iron homeostasis underlie plant defense responses. J Cell Sci 120:596-605. doi: 10.1242/jcs.001362

Liu J, Zhu J, Zhang P, et al (2017) Silicon supplementation alters the composition of herbivore induced plant volatiles and enhances attraction of parasitoids to infested rice plants. Front Plant Sci 8:1-8. doi: 10.3389/fpls.2017.01265

Liu Y, He C (2017) A review of redox signaling and the control of MAP kinase pathway in plants. Redox Biol 11:192-204. doi: 10.1016/j.redox.2016.12.009

Löbmann MT, Vetukuri RR, de Zinger L, et al (2016) The occurrence of pathogen suppressive soils in Sweden in relation to soil biota, soil properties, and farming practices. Appl Soil Ecol 107:57-65. doi: 10.1016/j.apsoil.2016.05.011

Louda SM, Collinge SK (1992) Plant resistance to insect herbivores: a field test of the environmental stress 
Love CJ, Zhang S, Mershin A (2008) Source of sustained voltage difference between the xylem of a potted ficus benjamina tree and its soil. PLoS One 3:1-5. doi: 10.1371/journal.pone.0002963

Lu H, McClung CR, Zhang C (2017) Tick tock: Circadian regulation of plant innate immunity. Annu Rev Phytopathol 55:287-311. doi: 10.1146/annurev-phyto-080516-035451

Lu Y, Yao J (2018) Chloroplasts at the crossroad of photosynthesis, pathogen infection and plant defense. Int J Mol Sci 19:1-37. doi: 10.3390/ijms19123900

Lushchak VI (2014) Free radicals, reactive oxygen species, oxidative stress and its classification. Chem Biol Interact 224:164-175. doi: 10.1016/j.cbi.2014.10.016

Maai E, Nishimura K, Takisawa R, Nakazaki T (2019) Light stress-induced chloroplast movement and midday depression of photosynthesis in sorghum leaves. Plant Prod Sci 00:1-10. doi: 10.1080/1343943X.2019.1673666

Mackenzie JS, Jeggo M (2019) The one health approach-why is it so important? Trop Med Infect Dis 4:5-8. doi: 10.3390/tropicalmed4020088

Madigan AP, Egidi E, Bedon F, et al (2019) Bacterial and fungal communities are differentially modified by melatonin in agricultural soils under abiotic stress. Front Microbiol 10:. doi: 10.3389/fmicb.2019.02616

Manivannan A, Soundararajan P, Cho YS, et al (2018) Sources of silicon influence photosystem and redox Biosyst 152:704-710. doi: 10.1080/11263504.2017.1320312

Marschner H (1995) Mineral nutrition of higher plants, Second edi. Academic press Publishing

Marschner H, Römheld V, Horst WJ, Martin P (1986) Root- induced changes in the rhizosphere: Importance for the mineral nutrition of plants. Zeitschrift für Pflanzenernährung und Bodenkd 149:441-456. doi: 10.1002/jpln. 19861490408

Marschner P (2011) Rhizosphere biology. In: Marschner's Mineral Nutrition of Higher Plants: Third Edition. Elsevier, pp 369-388 doi:10.1016/B978-0-12-384905-2.00015-7

Martínez M, Arata AF, Lázaro L, et al (2019) Effects of waterlogging stress on plant-pathogen interaction between Fusarium poae and wheat/ barley. Acta Sci - Agron 41:1-9. doi: 10.4025/actasciagron.v41i1.42629

Masiello CA, Gallagher ME, Randerson JT, et al (2008) Evaluating two experimental approaches for measuring ecosystem carbon oxidation state and oxidative ratio. J Geophys Res Biogeosciences 113:1-9. doi: 10.1029/2007JG000534

Masoero G, Cugnetto A (2018) The Raw pH in plants: A multifaceted parameter. J Agron Res 1:18-34. doi: 10.14302/issn.2639-3166.jar-18-2397

Matthysse AG (2006) The genus Agrobacterium. In: Dworkin M, Falkow S, Rosenberg E, et al. (eds) The Prokaryotes. Springer New York, New York, NY, pp 91-114

Mbengue M, Navaud O, Peyraud R, et al (2016) Emerging trends in molecular interactions between plants and the broad host range fungal pathogens Botrytis cinerea and Sclerotinia sclerotiorum. Front Plant Sci 7:1-9. doi: $10.3389 /$ fpls.2016.00422

McCall AC, Fordyce JA (2010) Can optimal defense theory be used to predict the distribution of plant chemical defenses? J Ecol 98:985-992. doi: 10.1111/j.1365-2745.2010.01693.x 
Mehdy MC (1994) Active oxygen species in plant defense against pathogens. Plant Physiol 105:467-472

Meisner A, De Boer W (2018) Strategies to maintain natural biocontrol of soil-borne crop diseases during severe drought and rainfall events. Front Microbiol 9:1-8. doi: 10.3389/fmicb.2018.02279

2143

2144

2145

2146

2147

2148

2149

2150

2151

2152

2153

2154

2155

2156

2157

2158

2159

2160

2161

2162

2163

2164

2165

2166

2167

2168

2169

2170

2171

2172

Melakerberhan H, Jones AL, Hanson E, Bird GW (1995) Effect of low soil pH on aluminum availability and on mortality of cherry seedlings. Plant Dis 79:886-892

Méthot PO, Alizon S (2014) What is a pathogen? Toward a process view of host-parasite interactions. Virulence 5:775-785. doi: 10.4161/21505594.2014.960726

Mhlongo MI, Piater LA, Madala NE, et al (2018) The chemistry of plant-microbe interactions in the rhizosphere and the potential for metabolomics to reveal signaling related to defense priming and induced systemic resistance. Front Plant Sci 9:1-17. doi: 10.3389/fpls.2018.00112

Miles PW, Oertli JJ (1993) The significance of antioxidants in the aphid-plant interaction. The redox hypothesis. Entomol Exp Appl 67:275-283

Miyara I, Shnaiderman C, Meng X, et al (2012) Role of nitrogen-metabolism genes expressed during pathogenicity of the alkalinizing Colletotrichum gloeosporioides and their differential expression in acidifying pathogens. Mol Plant-Microbe Interact 25:1251-1263. doi: 10.1094/MPMI-01-12-0017-R

Moebius-Clune BN, D.J. M-C, Gugino BK, et al (2017) Comprehensive assessment of soil health - The Cornell framework manual, Edition3.2. New York

Molki B, Thi Ha P, Mohamed A, et al (2019) Physiochemical changes mediated by "Candidatus Liberibacter asiaticus" in Asian citrus psyllids. Sci Rep 9:1-9. doi: 10.1038/s41598-019-52692-7

Morabito D, Guerrier G (2000) The free oxygen radical scavenging enzymes and redox status in roots and leaves of Populus $x$ Euramericana in response to osmotic stress, desiccation and rehydration. J Plant Physiol 157:74-80. doi: 10.1016/S0176-1617(00)80138-8

Morris BM, Reid B, Gow NAR (1995) Tactic response of zoospores of the fungus Phytophthora palmivora to solutions of different $\mathrm{pH}$ in relation to plant infection. Microbiology 141:1231-1237. doi: 10.1099/13500872-141-5-1231

Morris CE, Lamichhane JR, Nikolić I, et al (2019) The overlapping continuum of host range among strains in the Pseudomonas syringae complex. Phytopathol Res 1:1-16. doi: 10.1186/s42483-018-0010-6

Mühling KH, Plieth C, Hansen UP, Sattelmacher B (1995) Apoplastic ph of intact leaves of Vicia faba as influenced by light. J Exp Bot 46:377-382. doi: 10.1093/jxb/46.4.377

Müller-Schüssele SJ, Wang R, Gütle DD, et al (2020) Chloroplasts require glutathione reductase to balance reactive oxygen species and maintain efficient photosynthesis. Plant J 103:1140-1154. doi: $10.1111 /$ tpj.14791

Mullineaux P, Rausch T (2005) Glutathione, photosynthesis and the redox regulation of stress-responsive gene expression. Photosynth Res 86:459-474

Murdock LL, Brookhart G, Dunn PE, et al (1987) Cysteine digestive proteinases in Coleoptera. Comp Biochem Physiol -- Part B Biochem 87:783-787. doi: 10.1016/0305-0491(87)90388-9

Nachin L, Barras F (2000) External pH: An environmental signal that helps to rationalize pel gene duplication in Erwinia chrysanthemi. Mol Plant-Microbe Interact 13:882-886. doi: 10.1094/MPMI.2000.13.8.882

Nagel M, Seal CE, Colville L, et al (2019) Wheat seed ageing viewed through the cellular redox environment and changes in pH. Free Radic Res 53:641-654. doi: 10.1080/10715762.2019.1620226 
Napoleão TA, Soares G, Vital CE, et al (2017) Methyl jasmonate and salicylic acid are able to modify cell wall but only salicylic acid alters biomass digestibility in the model grass Brachypodium distachyon. Plant Sci 263:46-54. doi: 10.1016/j.plantsci.2017.06.014

2183

2184

2185

2186

2187

2188

2189

2190

2191

2192

2193

2194

2195

2196

2197

2198

2199

2200

2201

2202

2203

2204

2205

2206

2207

2208

2209

2210

2211

2212

2213

2214

2215

2216

2217

2218

2219

Nelson EB (2018) The seed microbiome: Origins, interactions, and impacts. Plant Soil 422:7-34. doi: 10.1007/s11104-017-3289-7

Newland PL, Hunt E, Sharkh SM, et al (2008) Static electric field detection and behavioural avoidance in cockroaches. J Exp Biol 211:3682-3690. doi: 10.1242/jeb.019901

Nguyen D, D’Agostino N, Tytgat TOG, et al (2016) Drought and flooding have distinct effects on herbivoreinduced responses and resistance in Solanum dulcamara. Plant Cell Environ 39:1485-1499. doi: $10.1111 /$ pce. 12708

Njenga KW, Nyaboga E, Wagacha JM, Mwaura FB (2017) Silicon induces resistance to bacterial blight by altering the physiology and antioxidant enzyme activities in cassava. World J Agric Res 5:42-51. doi: 10.12691/wjar-5-1-6

Nobori T, Tsuda K (2019) The plant immune system in heterogeneous environments. Curr Opin Plant Biol 50:58-66. doi: 10.1016/j.pbi.2019.02.003

Noctor G (2006) Metabolic signalling in defense and stress: the central roles of soluble redox couples. Plant Cell Environ 29:409-425

Noctor G, De Paepe R, Foyer CH (2007) Mitochondrial redox biology and homeostasis in plants. Trends Plant Sci 12:125-34. doi: 10.1016/j.tplants.2007.01.005

Noctor G, Queval G, Mhamdi A, et al (2011) Glutathione. Arab B 9:e0142. doi: 10.1199/tab.0142

Norton JM, Harman GE (1985) Responses of soil microorganisms to volatile exudates from germinating pea seeds. Can J Bot 63:1040-1045. doi: 10.1139/b85-142

Ntarlagiannis D, Atekwana EA, Hill EA, Gorby Y (2007) Microbial nanowires: Is the subsurface "hardwired"? Geophys Res Lett 34:3-7. doi: 10.1029/2007GL030426

Oka Y (2010) Mechanisms of nematode suppression by organic soil amendments-A review. Appl Soil Ecol 44:101-115. doi: 10.1016/j.apsoil.2009.11.003

Ongena M, Jourdan E, Schäfer M, et al (2005) Isolation of an N-alkylated benzylamine derivative from Pseudomonas putida BTP1 as elicitor of induced systemic resistance in bean. Mol Plant-Microbe Interact 18:562-569. doi: 10.1094/MPMI-18-0562

Opalka N, Brugidou C, Bonneau C, et al (1998) Movement of rice yellow mottle virus between xylem cells through pit membranes. Proc Natl Acad Sci U S A 95:3323-8. doi: 10.1073/pnas.95.6.3323

Ort DR (2001) When there is too much light. Plant Physiol 125:29-32. doi: 10.1104/pp.125.1.29

Ortega A, Garrido I, Casimiro I, Espinosa F (2017) Effects of antimony on redox activities and antioxidant defense systems in sunflower (Helianthus annuus L.) plants. PLoS One 12:1-21. doi: 10.1371/journal.pone.0183991

Padan E, Bibi E, Ito M, Krulwich TA (2005) Alkaline pH homeostasis in bacteria: New insights. Biochim Biophys Acta - Biomembr 1717:67-88. doi: 10.1016/j.bbamem.2005.09.010

Padmanabhan SY, Ganguly D (1954) Relation between the age of rice plant and its susceptibility to Helminthosporium and blast diseases. Proc Indian Acad Sci - Sect B 39:44-50. doi: 10.1007/BF03050372

Pandey P, Irulappan V, Bagavathiannan M V., Senthil-Kumar M (2017) Impact of combined abiotic and biotic 
stresses on plant growth and avenues for crop improvement by exploiting physio-morphological traits. Front Plant Sci 8:1-15. doi: 10.3389/fpls.2017.00537

2222

2223

2224

2225

2226

2227

2228

2229

2230

2231

2232

2233

2234

2235

2236

2237

2238

2239

2240

2241

2242

2243

2244

2245

2246

2247

2248

2249

2250

2251

2252

2253

2254

2255

2256

2257

2258

2259

Pandit TK, Mukkherjee D (2016) Cadmium enrichment in soil:plant physiological manifestation. In: Hemantarajan A (ed) Advances in plant physiology vol.17. Development and mechanisms underlying plant resilience to changing environment. Scientific Publishers (India), pp 141-185

Paradiso A, Caretto S, Leone A, et al (2016) ROS production and scavenging under anoxia and re-oxygenation in Arabidopsis cells: A balance between redox signaling and impairment. Front Plant Sci 7:1-11. doi: 10.3389/fpls.2016.01803

Pastor V, Luna E, Ton J, et al (2013) Fine tuning of reactive oxygen species homeostasis regulates primed immune responses in Arabidopsis. Mol Plant-Microbe Interact 26:1334-1344. doi: 10.1094/MPMI-04-130117-R

Pastori GM, Foyer CH (2002) Common components, networks, and pathways of cross- tolerance to stress. The central role of "Redox" and abscisic acid-mediated controls. Plant Physiol 129:460-468. doi: $10.1104 /$ pp.011021.460

Paszkowski U (2006) Mutualism and parasitism: the yin and yang of plant symbioses. Curr Opin Plant Biol 9:364-370. doi: 10.1016/j.pbi.2006.05.008

Paungfoo-Lonhienne C, Rentsch D, Robatzek S, et al (2010) Turning the table: Plants consume microbes as a source of nutrients. PLoS One 5:1-11. doi: 10.1371/journal.pone.0011915

Payne PA, Asher MJCC, Kershaw CD (1994) The incidence of Pythium spp. and Aphanomyces cochlioides associated with the sugar- beet growing soils of Britain. Plant Pathol 43:300-308. doi: 10.1111/j.13653059.1994.tb02688.x

Pedersen P, Tylka GL, Mallarino A, et al (2010) Correlation between soil pH, Heterodera glycines population densities, and soybean yield. Crop Sci 50:1458-1464. doi: 10.2135/cropsci2009.08.0432

Perazzolli M, Roatti B, Bozza E, Pertot I (2011) Trichoderma harzianum T39 induces resistance against downy mildew by priming for defense without costs for grapevine. Biol Control 58:74-82. doi:

10.1016/j.biocontrol.2011.04.006

Pett-Ridge J, Firestone MK (2005) Redox fluctuation structures microbial communities in a wet tropical soil. Appl Environ Microbiol 71:6998-7007. doi: 10.1128/AEM.71.11.6998

Pidello A (2014) Principes de chimie redox en écologie microbienne, QUAE. CIRAD, IFREMER, INRA, IRSTEA, Paris, France

Pisoschi AM, Pop A (2015) The role of antioxidants in the chemistry of oxidative stress: A review. Eur J Med Chem 97:55-74. doi: 10.1016/j.ejmech.2015.04.040

Pitann B, Schubert S, Mühling KH (2009) Decline in leaf growth under salt stress is due to an inhibition of $\mathrm{H}^{+}$pumping activity and increase in apoplastic $\mathrm{pH}$ of maize leaves. J Plant Nutr Soil Sci 172:535-543. doi: 10.1002/jpln.200800349

Podgórska A, Burian M, Szal B (2017) Extra-cellular but extra-ordinarily important for cells: Apoplastic reactive oxygen species metabolism. Front Plant Sci 8:1-20. doi: 10.3389/fpls.2017.01353

Pollard M, Beisson F, Li Y, Ohlrogge JB (2008) Building lipid barriers: biosynthesis of cutin and suberin. Trends Plant Sci 13:236-246. doi: 10.1016/j.tplants.2008.03.003

Ponnamperuma FN (1972) The chemistry of submerged soils. Adv Agron 24:29-96 
Pörtner HO (1987) Contributions of anaerobic metabolism to $\mathrm{pH}$ regulation in animal tissues: theory. J Exp Biol 131:69-87

Potters G, Horemans N, Jansen MAKK (2010) The cellular redox state in plant stress biology - A charging concept. Plant Physiol Biochem 48:292-300. doi: 10.1016/j.plaphy.2009.12.007

Prasch CM, Sonnewald U (2015) Signaling events in plants: Stress factors in combination change the picture. Environ Exp Bot 114:4-14. doi: 10.1016/J.ENVEXPBOT.2014.06.020

Prusky D, Yakoby N (2003) Pathogenic fungi: Leading or led by ambient pH? Mol Plant Pathol 4:509-516. doi: 10.1046/j.1364-3703.2003.00196.x

Purdy LH (1979) Sclerotinia sclerotiorum : History, diseases and symptomatology, host range, geographic distribution, and impact. Phytopathology 69:875. doi: 10.1094/phyto-69-875

Qi PF, Balcerzak M, Rocheleau H, et al (2016) Jasmonic acid and abscisic acid play important roles in hostpathogen interaction between Fusarium graminearum and wheat during the early stages of fusarium head blight. Physiol Mol Plant Pathol 93:39-48. doi: 10.1016/j.pmpp.2015.12.004

Raaijmakers JM, Paulitz TC, Steinberg C, et al (2009) The rhizosphere: A playground and battlefield for soilborne pathogens and beneficial microorganisms. Plant Soil 321:341-361. doi: 10.1007/s11104-0089568-6

Rabotnova IL, Schwartz W (1962) The importance of physical-chemical factors ( $\mathrm{pH}$ and $\mathrm{rH}_{2}$ ) for the life activity of microorganisms. VEB Gustav Fisher Verlag, Jena

Raghavendra AS, Yin ZH, Heber U (1993) Light-dependent pH changes in leaves of C4 plants Comparison of the $\mathrm{pH}$ response to carbon dioxide and oxygen with that of $\mathrm{C} 3$ plants. Planta 189:278-287. doi: 10.1007/BF00195087

Ramegowda V, Senthil-Kumar M (2015) The interactive effects of simultaneous biotic and abiotic stresses on plants: Mechanistic understanding from drought and pathogen combination. J Plant Physiol 176:47-54. doi: 10.1016/j.jplph.2014.11.008

Ranieri A, Castagna A, Baldan B, Soldatini GF (2001) Iron deficiency differently affects peroxidase isoforms in sunflower. J Exp Bot 52:25-35. doi: 10.1093/jxb/52.354.25

Ranjit SL, Manish P, Penna S (2016) Early osmotic, antioxidant, ionic, and redox responses to salinity in leaves and roots of Indian mustard (Brassica juncea L.). Protoplasma 253:101-110. doi: 10.1007/s00709-0150792-7

Rasool B, McGowan J, Pastok D, et al (2017) Redox control of aphid resistance through altered cell wall composition and nutritional quality. Plant Physiol 175:259-271. doi: 10.1104/pp.17.00625

Ratnadass A, Deguine J-P (2021) Crop protection practices and viral zoonotic risks within a One Health framework. Sci Total Environ 774:145172. doi: 10.1016/j.scitotenv.2021.145172

Reicosky DC, Dugas WA, Torbert HA (1997) Tillage-induced soil carbon dioxide loss from different cropping systems. Soil Tillage Res 41:105-118. doi: 10.1016/S0167-1987(96)01080-X

Rempelos L, Almuayrifi MSB, Baranski M, et al (2020) The effect of agronomic factors on crop health and performance of winter wheat varieties bred for the conventional and the low input farming sector. F Crop Res 254:. doi: 10.1016/j.fcr.2020.107822

2299 Reniere ML (2018) Reduce, induce, thrive: Bacterial redox sensing during pathogenesis. J Bacteriol 200:1-12. 
doi: $10.1128 / \mathrm{jb} .00128-18$

2301

2302

2303

2304

2305

2306

2307

2308

2309

2310

2311

2312

2313

2314

2315

2316

2317

2318

2319

2320

2321

2322

2323

2324

2325

2326

2327

2328

2329

2330

2331

2332

2333

2334

2335

2336

2337

2338

2339

Rocher F, Chollet J-F, Jousse C, Bonnemain J (2006) Salicylic acid, an ambimobile molecule exhibiting a high ability to accumulate in the phloem. Plant Physiol 141:1684-1693. doi: 10.1104/pp.106.082537.upper

Rolfe SA, Griffiths J, Ton J (2019) Crying out for help with root exudates: adaptive mechanisms by which stressed plants assemble health-promoting soil microbiomes. Curr Opin Microbiol 49:73-82. doi: 10.1016/j.mib.2019.10.003

Rouxel T, Balesdent MH (2005) The stem canker (blackleg) fungus, Leptosphaeria maculans, enters the genomic era. Mol Plant Pathol 6:225-241. doi: 10.1111/j.1364-3703.2005.00282.x

Saharan GS, Mehta N, Saharan, G. S.; Mehta N (2007) Sclerotinia Diseases of Crop Plants: Biology, Ecology and Disease Management

Sakr N (2016) Silicon control of bacterial and viral diseases in plants. J Plant Prot Res 56:331-336. doi: 10.1515/jppr-2016-0052

Salazar C, Hernández C, Pino MT (2015) Plant water stress: Associations between ethylene and abscisic acid response. Chil J Agric Res 75:71-79. doi: 10.4067/S0718-58392015000300008

Samuels L, Kunst L, Jetter R (2008) Sealing plant surfaces: Cuticular wax formation by epidermal cells. Annu Rev Plant Biol 59:683-707. doi: 10.1146/annurev.arplant.59.103006.093219

Santo-Domingo J, Demaurex N (2012) Perspectives on: SGP Symposium on mitochondrial physiology and medicine: The renaissance of mitochondrial pH. J Gen Physiol 139:415-423. doi: 10.1085/jgp.201110767

Schimel J, Balser TC, Wallenstein M (2007) Microbial stress response physiology and its implications for ecosystem function. Ecology 88:1386-1394

Schimel JP, Schaeffer SM (2012) Microbial control over carbon cycling in soil. Front Microbiol 3:1-11. doi: 10.3389/fmicb.2012.00348

Schlatter D, Kinkel L, Thomashow L, et al (2017) Disease suppressive soils: New insights from the soil microbiome. Phytopathology 107:1284-1297. doi: 10.1094/PHYTO-03-17-0111-RVW

Schmidke I, Krüger C, Frömmichen R, et al (1999) Phloem loading and transport characteristics of iron in interaction with plant-endogenous ligands in castor bean seedlings. Physiol Plant 106:82-89. doi: 10.1034/j.1399-3054.1999.106112.x

Schneider R (ed) (1982) Suppressive soils and plant disease. The American phytopathological society, St Paul, Minnesota, USA

Schoeneweiss DF (1975) Predisposition, stress, and plant disease. Annu Rev Phytopathol 13:193-211

Schwarzländer M, Fricker MD, Müller C, et al (2008) Confocal imaging of glutathione redox potential in living plant cells. J Microsc 231:299-316. doi: 10.1111/j.1365-2818.2008.02030.x

Seabloom EW, Borer ET, Gross K, et al (2015) The community ecology of pathogens: Coinfection, coexistence and community composition. Ecol Lett 18:401-415. doi: 10.1111/ele.12418

Secchi F, Zwieniecki MA (2016) Accumulation of sugars in the xylem apoplast observed under water stress conditions is controlled by xylem pH. Plant Cell Environ 39:2350-2360. doi: 10.1111/pce.12767

Segal LM, Wilson RA (2018) Reactive oxygen species metabolism and plant-fungal interactions. Fungal Genet Biol 110:1-9. doi: 10.1016/j.fgb.2017.12.003

Sen Y, van der Wolf J, Visser R, van Heusden S (2015) Bacterial canker of tomato: current knowledge of detection, management, resistance, and interactions. Plant Dis 99:4-13 
Serrano I, Audran C, Rivas S (2016) Chloroplasts at work during plant innate immunity. J Exp Bot 67:38453854. doi: 10.1093/jxb/erw088

Sewelam N, Kazan K, Schenk PM (2016) Global plant stress signaling : Reactive oxygen species at the cross road. Front Plant Sci 7:1-21. doi: 10.3389/fpls.2016.00187

Shah SRA, Tao L, Haijuan C, et al (2015) Age-related resistance and the defense signaling pathway of Ph-3 gene against Phytophthora infestans in tomatoes. Hortic Plant J 1:70-76. doi: 10.16420/j.issn.20959885.2015-0019

Shah TH (2017) Plant nutrients and insects development. Int J Entomol Res 2:54-57

Shao HB, Chy LY, Shao MA, et al (2008) Higher plant antioxidants and redox signaling under environmental stresses. C R Biol 331:433-41. doi: 10.1016/j.crvi.2008.03.011

Shapiro-Ilan DI, Lewis EE, Campbell JF, Kim-Shapiro DB (2012) Directional movement of entomopathogenic nematodes in response to electrical field: Effects of species, magnitude of voltage, and infective juvenile age. J Invertebr Pathol 109:34-40. doi: 10.1016/j.jip.2011.09.004

Shi S, Richardson AE, O’Callaghan M, et al (2011) Effects of selected root exudate components on soil bacterial communities. FEMS Microbiol Ecol 77:600-610. doi: 10.1111/j.1574-6941.2011.01150.x

Shikano I, Ericsson JD, Cory JS, Myers JH (2010) Indirect plant-mediated effects on insect immunity and disease resistance in a tritrophic system. Basic Appl Ecol 11:15-22. doi: 10.1016/j.baae.2009.06.008

Shrestha R, Lee SH, Hur JH, Lim CK (2005) The effects of temperature, pH, and bactericides on the growth of Erwinia pyrifoliae and Erwinia amylovora. Plant Pathol J 21:127-131. doi: 10.5423/PPJ.2005.21.2.127

Sierla M, Rahikainen M, Salojärvi J, et al (2013) Apoplastic and chloroplastic redox signaling networks in plant stress responses. Antioxid Redox Signal 18:2220-39. doi: 10.1089/ars.2012.5016

Simpfendorfer S, Harden TJ, Murray GM (2001) Effect of temperature and pH on the growth and sporulation of Phytophthora clandestina. Australas Plant Pathol 30:1-5. doi: 10.1071/AP00054

Singh A, Jain A, Sarma BK, et al (2013) Rhizosphere microbes facilitate redox homeostasis in Cicer arietinum against biotic stress. Ann Appl Biol 163:33-46. doi: 10.1111/aab.12030

Singh B, Schulze DG (2015) Soil minerals and plant nutrition. Nat Educ Knowl 6:1-6

Singh JS, Kumar A, Rai AN, Singh DP (2016) Cyanobacteria: A precious bio-resource in agriculture, ecosystem, and environmental sustainability. Front Microbiol 7:1-19. doi: 10.3389/fmicb.2016.00529

Smiley R, Cook R (1972) Relationship between take-all of wheat and rhizosphere $\mathrm{pH}$ in soils fertilized with ammonium vs. nitrate-nitrogen. Phytopathology 63:882-890

Sobrino-plata J, Meyssen D, Cuypers A, et al (2014) Glutathione is a key antioxidant metabolite to cope with mercury and cadmium stress. Plant Soil 377:369-381. doi: 10.1007/s11104-013-2006-4

Soengas P, Rodríguez VM, Velasco P, Cartea ME (2018) Effect of temperature stress on antioxidant defenses in Brassica oleracea. ACS Omega 3:5237-5243. doi: 10.1021/acsomega.8b00242

Song Y, Deng SP, Acosta-Martinez V, et al (2008) Characterization of redox-related soil microbial communities along a river floodplain continuum by fatty acid methyl ester (FAME) and 16S rRNA genes. Appl Soil Ecol 40:499-509. doi: 10.1016/j.apsoil.2008.07.005

Sorauer P (1974) Handbuch der Pflanzenkrankheiten. Hempel und Parey, Wiegandt, Berlin

Soundararajan P, Manivannan A, Ko CH, Jeong BR (2018) Silicon enhanced redox homeostasis and protein expression to mitigate the salinity stress in Rosa hybrida 'Rock Fire.' J Plant Growth Regul 37:16-34. doi: 
Spann TM, Schumann AW (2010) Mineral nutrition contributes to plant disease and pest resistance. Univ Florida IFAS Ext HS1181:1-5

Spoel SH, Loake GJ (2011) Redox-based protein modifications: The missing link in plant immune signalling. Curr Opin Plant Biol 14:358-364. doi: 10.1016/j.pbi.2011.03.007

Srivastava A, Atomic B, Redij T (2017) Crosstalk of plant hormone and redox oxidation states signal transduction in plant interaction of other components with phytohormones. In: Pandey G (ed) Mechanism of Plant Hormone Signaling under Stress, First. John Wiley \& Sons, pp 3-22

Stacy A, Fleming D, Lamont RJ, et al (2016) A commensal bacterium promotes virulence of an opportunistic pathogen via cross-respiration. MBio 7:e00782. doi: 10.1128/mBio.00782-16

Steinberg C, Edel-Hermann V, Alabouvette C, Lemanceau P (2019) Soil suppressiveness to plant diseases. In: Van Elsas JD, Jansson J TJ (ed) Modern Soil Microbiology. Press Taylor \& Francis Group, New York, pp $345-361$

Steinmetz NF, Lomonossoff GP, Evans DJ (2006) Decoration of cowpea mosaic virus with multiple, redoxactive, organometallic complexes. Small 2:530-533. doi: 10.1002/smll.200500453

Su PH, Lai YH (2017) A reliable and non-destructive method for monitoring the stromal $\mathrm{pH}$ in isolated chloroplasts using a fluorescent pH probe. Front Plant Sci 8:1-10. doi: 10.3389/fpls.2017.02079 sativa L.) seedlings. Plant Soil 323-338. doi: 10.1007/s11104-020-04710-1

Šustr V, Stingl U, Brune A (2014) Microprofiles of oxygen, redox potential, and pH, and microbial fermentation products in the highly alkaline gut of the saprophagous larva of Penthetria holosericea (Diptera: Bibionidae). J Insect Physiol 67:64-69. doi: 10.1016/j.jinsphys.2014.06.007

Suzuki T, Shinogi T, Narusaka Y, Park P (2003) Infection behavior of Alternaria alternata Japanese pear pathotype and localization of 1,3- $\beta$ - $d$-glucan in compatible and incompatible interactions between the pathogen and host plants. J Gen Plant Pathol 69:91-100. doi: 10.1007/s10327-002-0001-3

Tano BF, Brou CY, Dossou-yovo ER, et al (2020) Spatial and temporal variability of soil redox potential , pH and electrical conductivity across a toposequence in the savanna of West Africa. Agronomy 10:1787. doi: doi:10.3390/agronomy10111787

Teixeira PJP, Colaianni NR, Fitzpatrick CR, Dangl JL (2019) Beyond pathogens: microbiota interactions with the plant immune system. Curr Opin Microbiol 49:7-17. doi: 10.1016/j.mib.2019.08.003

Thivierge K, Prado A, Driscoll BT, et al (2010) Caterpillar- and salivary-specific modification of plant proteins. J Proteome Res 5887-5895

Thomma BPHJ, Nürnberger T, Joosten MHAJ (2011) Of PAMPs and effectors: The blurred PTI-ETI dichotomy. Plant Cell 23:4-15. doi: 10.1105/tpc.110.082602

Thompson IA, Huber DM (2007) Manganese and plant disease. In: Datnoff LE, Elmer WH, Huber DM (eds) Mineral nutrition and plant diseases. The American Phytopathology Society, pp 139-153

Thomson CJ, Greenway H (1991) Metabolic evidence for stelar anoxia in maize roots exposed to low $\mathrm{O}_{2}$ concentrations. Plant Physiol 96:1294-1301. doi: 10.1104/pp.96.4.1294

Tollenaere C, Lacombe S, Wonni I, et al (2017) Virus-bacteria rice co-infection in Africa: field estimation, reciprocal effects, molecular mechanisms, and evolutionary implications. Front plant Sci 8:. doi: 
Torres MA, Jones JDG, Dangl JL (2006) Reactive oxygen species signaling in response to pathogens. Plant Physiol 141:373-378. doi: 10.1104/pp.106.079467

2423

Toyota K, Shirai S (2018) Growing interest in microbiome research unraveling disease suppressive soils against plant pathogens. Microbes Environ 33:345-347. doi: 10.1264/jsme2.ME3304rh

Tsang EWT, Bowler C, Herouart D, et al (1991) Differential regulation of superoxide dismutases in plants exposed to environmental stress. Plant Cell 3:783-792

Ursini F, Maiorino M, Forman HJ (2016) Redox homeostasis: The Golden Mean of healthy living. Redox Biol 8:205-215. doi: 10.1016/j.redox.2016.01.010

Usha Rani P, Pratyusha S (2013) Defensive role of Gossypium hirsutum L. anti-oxidative enzymes and phenolic acids in response to Spodoptera litura F. feeding. J Asia Pac Entomol 16:131-136. doi: 10.1016/j.aspen.2013.01.001

Van Baarlen P, Van Belkum A, Summerbell RC, et al (2007) Molecular mechanisms of pathogenicity: How do pathogenic microorganisms develop cross-kingdom host jumps? FEMS Microbiol Rev 31:239-277. doi: 10.1111/j.1574-6976.2007.00065.x

Van Bel AJE, Gaupels F (2004) Pathogen-induced resistance and alarm signals in the phloem. Mol Plant Pathol 5:495-504. doi: 10.1111/J.1364-3703.2004.00243.X

Van Bruggen AHC, Semenov AM (2000) In search of biological indicators for soil health and disease suppression. Appl Soil Ecol 15:13-24. doi: 10.1016/S0929-1393(00)00068-8

Van Buyten E, Höfte M (2013) Pythium species from rice roots differ in virulence, host colonization and nutritional profile. BMC Plant Biol 13:. doi: 10.1186/1471-2229-13-203

Van Dongen JT, Schurr U, Pfister M, Geigenberger P (2003) Phloem metabolism and function have to cope with low internal oxygen. Plant Physiol 131:1529-1543. doi: 10.1104/pp.102.017202

van Haperen P, Voorrips RE, van Loon JJA, Vosman B (2019) The effect of plant development on thrips resistance in Capsicum. Arthropod Plant Interact 13:11-18. doi: 10.1007/s11829-018-9645-6

Van West P, Appiah AA, Gow NAR (2003) Advances in research on oomycete root pathogens. Physiol Mol Plant Pathol 62:99-113. doi: 10.1016/S0885-5765(03)00044-4

van West P, Morris BM, Reid B, et al (2002) Oomycete plant pathogens use electric fields to target roots. Mol Plant Microbe Interact 15:790-798. doi: 10.1094/MPMI.2002.15.8.790

Vartoukian SR, Palmer RM, Wade WG (2010) Strategies for culture of "unculturable” bacteria. FEMS Microbiol Lett 309:1-7. doi: 10.1111/j.1574-6968.2010.02000.x

Veivers PC, O’Brien RW, Slaytor M (1980) The redox state of the gut of termites. J Insect Physiol 26:75-77

Venard C, Vaillancourt L (2007) Colonization of fiber cells by Colletotrichum graminicola in wounded maize stalks. Phytopathology 97:438-447. doi: 10.1094/PHYTO-97-4-0438

Visnovitz T, Touati M, Miller AJ, Fricke W (2013) Apoplast acidification in growing barley (Hordeum vulgare L.) leaves. J Plant Growth Regul 32:131-139. doi: 10.1007/s00344-012-9282-8

Voges MJEEE, Bai Y, Schulze-Lefert P, Sattely ES (2019) Plant-derived coumarins shape the composition of an Arabidopsis synthetic root microbiome. Proc Natl Acad Sci U S A 116:12558-12565. doi: 10.1073/pnas.1820691116

Vozáry E, Jócsák I, Droppa M, Bóka K (2008) Connection between structural changes and electrical parameters 
of pea root tissue under anoxia. In: Pamella Padilla (ed) Anoxia. InTech, pp 131-146

2461

2462

2463

2464

2465

2466

2467

2468

2469

2470

2471

2472

2473

2474

2475

2476

2477

2478

2479

2480

2481

2482

2483

2484

2485

2486

2487

2488

2489

2490

2491

2492

2493

2494

2495

2496

2497

2498

2499

Wagner E, Abrechtová JTP, Normann J, Greppin H (2000) Redox state and phosphorylation potential as macroparameters in rhythmic control of metabolism - a molecular basis for seasonal adaptation of development BT - The Redox State and Circadian Rhythms. In: Driessche T Vanden, Guisset J-L, Petiaude Vries GM (eds). Springer Netherlands, Dordrecht, pp 257-277

Wang C yu, Zhou X, Guo D, et al (2019) Soil pH is the primary factor driving the distribution and function of microorganisms in farmland soils in northeastern China. Ann Microbiol 69:1461-1473. doi: $10.1007 / \mathrm{s} 13213-019-01529-9$

Wang JP, Xu YP, Zang XP, et al (2016) Sclerotinia sclerotiorum virulence is affected by mycelial age via reduction in oxalate biosynthesis. J Integr Agric 15:1034-1045. doi: 10.1016/S2095-3119(15)61199-6

Wang M, Chen S, Chen L, Wang D (2020) Microbial mechanisms responsible for the variation of soil Cd availability under different pe+pH environments. Ecotoxicol Environ Saf 206:111057. doi: 10.1016/j.ecoenv.2020.111057

Wang YC, Yu M, Shih PY, et al (2018) Stable pH suppresses defense signaling and is the key to enhance Agrobacterium-mediated transient expression in Arabidopsis seedlings. Sci Rep 8:1-9. doi: 10.1038/s41598-018-34949-9

War AR, Paulraj MG, Ahmad T, et al (2012) Mechanisms of plant defense against insect herbivores. Plant Signal Behav 7:1306-1320. doi: 10.4161/psb.21663

Ward GM (1960) Potassium in plant metabolism. III. Some carbohydratre changes in the wheat seedling associated with varying rates of potassium supply. Can J Plant Sci 40:729-735

Webb RW (1921) Studies in the physiology of the fungi . XV . Germination of the spores of certain fungi in relation to Hydrogen-ion concentration. Ann Missouri Bot Gard 8:283-341

Wei J, Loon JJA Van, Gols R, et al (2014) Reciprocal crosstalk between jasmonate and salicylate defensesignalling pathways modulates plant volatile emission and herbivore host-selection behaviour. J Exp Bot 65:3289-3298. doi: 10.1093/jxb/eru181

Weller DM, Raaijmakers JM, Gardener BBM, Thomashow LS (2002) Microbial populations responsible for specific soil suppressiveness to plant pathogens. Annu Rev Phytopathol 40:309-48. doi:

10.1146/annurev.phyto.40.030402.110010

Wells JM, Raju BC, Hung H, et al (1987) Xylella fastidiosa gen. nov. , sp. nov: Gram-Negative, XylemLimited, Fastidious Plant Bacteria Related to Xanthomonas spp. Int J Syst Bacteriol 37:136-143

Wezel A, Casagrande M, Celette F, et al (2014) Agroecological practices for sustainable agriculture. A review. Agron Sustain Dev 34:1-20. doi: 10.1007/s13593-013-0180-7

White JF, Kingsley KL, Zhang Q, et al (2019) Review: Endophytic microbes and their potential applications in crop management. Pest Manag Sci 75:2558-2565. doi: 10.1002/ps.5527

Wicklow DT, Jordan AM, Gloer JB (2009) Antifungal metabolites (monorden, monocillins I, II, III) from Colletotrichum graminicola, a systemic vascular pathogen of maize. Mycol Res 113:1433-1442. doi: 10.1016/j.mycres.2009.10.001

Wielkopolan B, Obre A (2016) Three-way interaction among plants , bacteria , and coleopteran insects. Planta 244:313-332. doi: 10.1007/s00425-016-2543-1

Wilkinson S (1999) PH as a stress signal. Plant Growth Regul 29:87-99. doi: 10.1023/A:1006203715640 
Wilkinson S, Davies WJ (1997) Xylem sap pH increase: A drought signal received at the apoplastic face of the guard cell that involves the suppression of saturable abscisic acid uptake by the epidermal symplast. Plant Physiol 113:559-573. doi: 10.1104/pp.113.2.559

Williams A, de Vries FT (2019) Plant root exudation under drought: implications for ecosystem functioning. New Phytol. doi: 10.1111/nph.16223

Williams B, Kabbage M, Kim HJ, et al (2011) Tipping the balance : Sclerotinia sclerotiorum secreted oxalic acid suppresses host defenses by manipulating the host redox environment. PLOS Pathog 7:e1002107. doi: 10.1371/journal.ppat.1002107

Wilts BD, Schaap IAT, Schmidt CF (2015) Swelling and softening of the cowpea chlorotic mottle virus in response to pH shifts. Biophys J 108:2541-2549. doi: 10.1016/j.bpj.2015.04.019

Wissenschafts B, Issn B, Physiology P, et al (1999) The role of extracellular $\mathrm{pH}$ homeostasis in potato resistance to ring rot pathogen. J Phytopathol 147:679-686

Worrall JJ, Adams GC, Tharp SC (2010) Summer heat and an epidemic of cytospora canker of Alnus. Can J Plant Pathol 32:376-386. doi: 10.1080/07060661.2010.499265

Wright JP, Fisher DB (1981) Measurement of the sieve tube membrane potential. Plant Physiol 67:845-848. doi: $10.1104 /$ pp.67.4.845

Xi B, Zhao X, He X, et al (2016) Successions and diversity of humic-reducing microorganisms and their association with physical-chemical parameters during composting. Bioresour Technol 219:204-211. doi: 10.1016/j.biortech.2016.07.120

Xie L, Zhang JZ, Cai L, Hyde KD (2010) Biology of Colletotrichum horii, the causal agent of persimmon anthracnose. Mycology 1:242-253. doi: 10.1080/21501203.2010.526644

Yadeta KA, Thomma BPHJ (2013) The xylem as battleground for plant hosts and vascular wilt pathogens. Front Plant Sci 4:1-12. doi: 10.3389/fpls.2013.00097

Yamamoto Y, Kobayashi Y, Devi SR, et al (2003) Oxidative stress triggered by aluminum in plant roots. In: J. A (ed) Roots: The Dynamic Interface between Plants and the Earth.Developments in Plant and Soil Sciences, vol 101. Springer, Dordrecht, The Netherlands, pp 239-243

Yang JW, Yi HS, Kim H, et al (2011) Whitefly infestation of pepper plants elicits defense responses against bacterial pathogens in leaves and roots and changes the below-ground microflora. J Ecol 99:46-56. doi: 10.1111/j.1365-2745.2010.01756.x

Yoder JI (2001) Host-plant recognition by parasitic Scrophulariaceae. Curr Opin Plant Biol 4:359-365

Yruela I (2013) Transition metals in plant photosynthesis. Metallomics 5:1090-1109. doi: 10.1039/c3mt00086a

Yu K, Pieterse CMJ, Bakker PAHM, Berendsen RL (2019) Beneficial microbes going underground of root immunity. Plant Cell Environ 42:2860-2870. doi: 10.1111/pce.13632

Yuan J, Zhao J, Wen T, et al (2018) Root exudates drive the soil-borne legacy of aboveground pathogen infection. Microbiome 6:1-12. doi: 10.1186/s40168-018-0537-x

Zebelo SA, Maffei ME (2015) Role of early signalling events in plant - insect interactions. J Exp Bot 66:435448. doi: $10.1093 / \mathrm{jxb} / \mathrm{eru} 480$

Zechmann B, Zellnig G, Urbanek-Krajnc A, Müller M (2007) Artificial elevation of glutathione affects symptom development in ZYMV-infected Cucurbita pepo L. plants. Arch Virol 152:747-762. doi: 10.1007/s00705006-0880-2 
Zhang J, Yan H, Xia M, et al (2020) Wheat root transcriptional responses against Gaeumannomyces graminis var. tritici. Phytopathol Res 2:23. doi: 10.1186/s42483-020-00071-w Zhang J, Zeng B, Mao Y, et al (2017) Melatonin alleviates aluminium toxicity through modulating antioxidative enzymes and enhancing organic acid anion exudation in soybean. Funct Plant Biol 44:961-968

Zou C, Zhang F (2003) Ammonium improves iron nutrition by decreasing leaf apoplastic $\mathrm{pH}$ of sunflower plants (Helianthus annuus L. cv. Frankasol). Chinese Sci Bull 48:2216-2221. doi: 10.1007/BF03182855 